\title{
The role of institutions on modern agricultural value chains
}

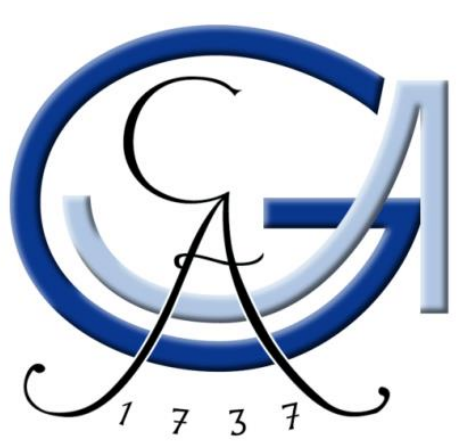

\section{Dissertation}

to obtain the Ph.D. degree

in the International Ph.D. Program for Agricultural Sciences in Göttingen (IPAG) at the Faculty of Agricultural Sciences,

Georg-August-University Göttingen, Germany

Submitted by

\section{Jessie Lin}

Born in Taipei, Taiwan

Göttingen, March 2020 
First Supervisor:

Second Supervisor:

Third Supervisor:
Prof. Stephan von Cramon-Taubadel

Prof. Richard Sexton

Prof. Meike Wollni

Date of defense: May 14, 2020 
"If you don't like something, change it. If you can't change it, change your attitude"

Maya Angelou

"Whatever you do may seem insignificant, but it is most important that you do it"

Mahatma Gandhi

"You may be disappointed if you fail, but you are doomed if you do not try"

Beverly Sills

"The essence of being human is that one does not seek perfection"

George Orwell 


\section{Executive Summary}

There has been an increase in the integration of global agricultural value chains in recent decades. This trend has created opportunities for smallholder farmers and agrifood industries in developing countries through forms of international exchange. At the same time, demographic changes and rising incomes across the developing world have affected the food security status of citizens in developing countries. Institutions have a prominent role to play in how integrated countries and smallholder farmers are in global value chains. This dissertation seeks to answer these questions first by studying coconut value chains. The first paper does this by first on a macro level by analyzing the role of institutions on the trade of coconut products. Second, I study a case study in Fiji qualitatively to understand the discourses and perceptions of farmers involved in coconut farming. Finally, the third paper takes a theoretical model to assess the effects of a transition of rural smallholder farming to selling or renting landholdings and supplying labor to larger commercial farms on the food security and economic welfare of in-country urban consumers. In line with the two previous papers, it emphasizes the importance of institutions since positive and negative institutional forces within the home country play a part in the persistence of smallholder farming.

Chapter 2 presents the first paper, titled "The role of institutional quality on the performance in the export of coconut products." It aimed to answer three research questions. First, we are interested in how the overall institutional environment in exporting countries affects the bilateral trade of coconut products. Second, we look into whether improvements in the exporters' individual indicator scores lead to an increase in trade with consideration to the exporters' and importers' overall institutional setting. Lastly, we investigate the effects of institutional similarities for coconut trade and its different compositions of value addition. To address these questions, we utilized structural gravity models to measure how institutional quality affects the trade performance of the top 26 coconut producing countries to the top 15 importing economies over the span of 20 years. The results suggest that increased government effectiveness enhances trade of high-value products, whereas better voice and accountability scores decrease the trade of coconut products in both categories of value addition.

The second paper, presented in Chapter 3, investigates the coconut value chain in Fiji. It is titled "Fiji's participation in the global coconut value chain: Opportunities and constraints." Field research was conducted in the islands of Fiji. I use predominately a qualitative approach to understand the rhetoric and discourses of each stakeholder group involved in the coconut sector and their perceptions of the challenges and opportunities. This chapter then follows the first paper and looks into the effect of institutional indicators on the performance in the export of 
coconut products from Fiji. The empirical results show that increased scores in the government's effectiveness and voice and accountability indicators enhance coconut exports from Fiji, suggesting that domestic institutions play an important role. Interviews with key actors reveal that communications among each stakeholder group are fragmented. The main institutional actors and the producers have different perceptions of the industry's challenges, thus resulting in different ideas on how to address the issues.

Chapter 4 of this dissertation is titled "Modern agricultural value chains and food security of urban consumers in developing countries." The work is a collaboration stemmed from my research stay at the University of California Davis. The study builds on previous research (Ma \& Sexton, forthcoming) that assessed the future of smallholder farming systems in modern agricultural value chains. Their findings show that smallholders gain higher incomes and larger production outputs when they can supply inputs and labor to large commercial farms compared to working on own small farms across a range of plausible market settings. We address the unanswered question of how this improved productivity effect can affect the welfare and food security of domestic smallholders and urban consumers. We obtain price elasticities of demand for staple food commodities in developing countries from 15 peer-reviewed articles. Based on these figures, we embed a demand-side framework into the Ma-Sexton model to study the impacts of land consolidation and the advent of commercial farming systems on the dietary diversity of home country urban consumers.

Some general conclusions and implications can be drawn from the results of these chapters. First, we confirm that institutions matter, but not merely as one entity. Different aspects of institutional quality affect integration differently. When assessing coconut producing countries collectively, the findings of our first paper suggest that government effectiveness matters the most when enhancing trade of coconut products of varying degrees of value edition, while the indicator, voice and accountability, had contrasting effects. However, chapter 3 demonstrates that for Fiji, a small island economy, both government effectiveness and voice and accountability increase Fiji's export of coconut products. This implies that the heterogeneities of each country play a role and must be taken into consideration for future research. Each country has its specific institutional set-up and enabling environment. The integration of each country will differ albeit to a lesser or greater degree than another.

Findings from the last paper suggest that urban consumers, especially the poorer households, can benefit when prices of staple crops increase. Their overall welfare and diet improve as a result. Smallholders also see an improvement in welfare as the utility in consumption and leisure increases. Though governments and international donors have an egalitarian and 
development in mind when implementing policies and strategies that support smallholder farming, our findings suggest that there is a large welfare gain if policies enable smallholders to supply land and labor to commercial farms. 


\section{Acknowledgments}

These last three years have been a journey that has shaped me in ways that extend further than my dissertation and academic work. I have grown as a person intellectually and emotionally. None of this would have been possible without the people who have been with me along the way.

I would first like to express my gratitude to Prof. Stephan von Cramon-Taubadel for all the support and guidance in the last three years. Stephan, your reassuring spirit and attitude have kept me motivated and encouraged even in the most difficult times. I greatly appreciate the independence and trust you have given me to pursue my research and goals. I have always enjoyed our chats! One day I will beat you in the Altstadtlauf!

Second, I would like to sincerely thank Prof. Richard Sexton for giving me the opportunity to be a part of the ARE family at the University of California, Davis. Rich, you welcomed me warmly from day one and supported me on a professional and personal level in the short 3.5 months that I was there. Thank you for also the opportunity to learn and work on a research topic that is out of my expertise. I can't express enough gratefulness and respect for the guidance you have given me.

I want to say a special thank you to Prof. Matin Qaim for being the leading force of GlobalFood. I am grateful for the opportunities that GlobalFood has provided me in these three years, and none of it would have been possible without you. Thank you to Prof. Meike Wollni for your supportive role as Vice Speaker of GlobalFood, and in acting as my third examiner. A thank you to Prof. Bernhard Bruemmer for your valuable inputs and feedback on my first paper.

I extend warm gratitude to Melanie, Katrin, and Ann-Kathrin in the coordination team. I appreciate your patience and efforts in making everything run smoothly for us in these years. You all make up the strong backbone of GlobalFood!

The road to finishing my dissertation has been a rollercoaster ride. I have had the great pleasure to be in the company and wisdom of my GlobalFood and departmental colleagues. I would like to especially give my love and thanks to Andrea, Anette, Bernhard, Brendan, Daniel, Dela, Denise, Dirk, Hamid, Jorge, Karina, Linda, Lisa, Luis, and Rudi for being there me emotionally and intellectually along the way. Your friendship means the world to me and I could not have done this without your support!

I would like to extend my appreciation to the Master's students, PhDs, Postdocs, Staff, and Faculty in the ARE department at the University of California, Davis. You all welcomed me with open arms and made me feel a part of the family. My time there was brief but invaluable. 
I am so thankful to have made so many friends and meaningful connections in such a short time. Ashley, thanks for being my unofficial buddy and my partner in crime in obsessing over movies! To all the friends that I have made throughout my journey from Utah to Washington, DC to Paris to Taiwan to Northern California to Hohenheim and now to Goettingen, I have been incredibly fortunate to have had you there for me along the way. I believe every encounter is a privilege, and I am honored to have made the acquaintance of so many wonderful people.

To my cousin Noemi, who I have been inseparable since the day of my birth. Thank you for being supportive and understanding of me throughout the past three decades during my good days and bad days.

Lastly, I would like to thank my parents for always supporting me in the decision to pursue my Ph.D. Thank you for being there for me during my struggles, I know it hasn't always been easy. All my love to both of you. 


\section{Table of Contents}

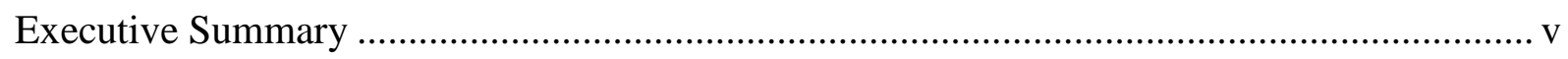

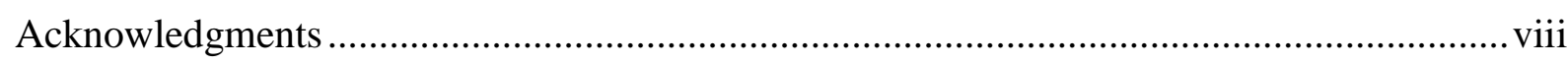

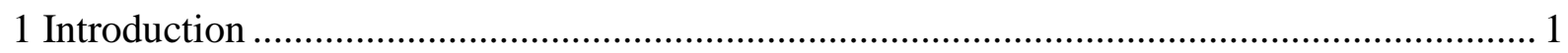

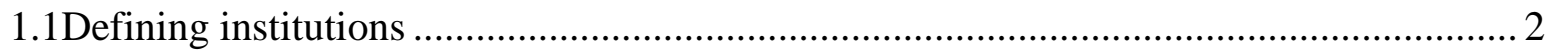

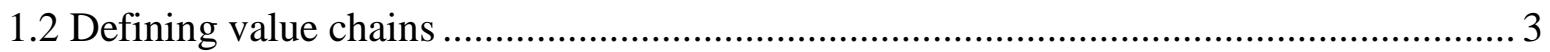

1.3 Linking institutions to global and modern agricultural value chains ............................ 4

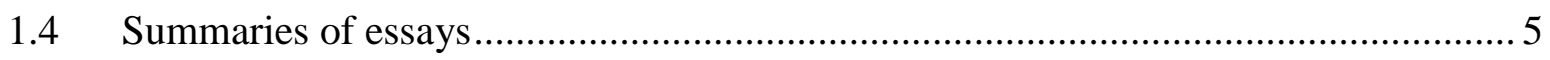

2 The role of institutional quality on the performance in the export of coconut products ......... 8

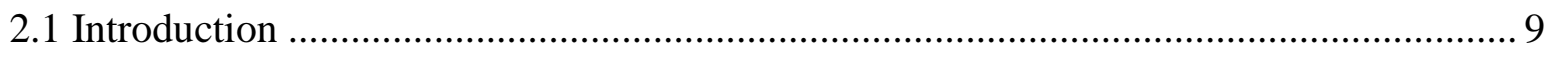

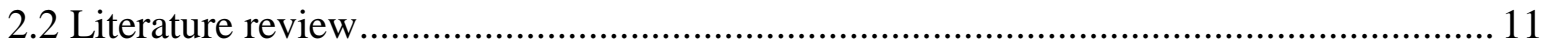

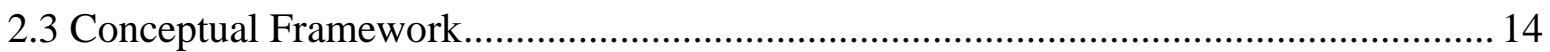

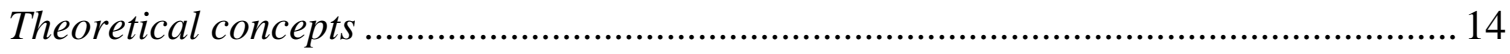

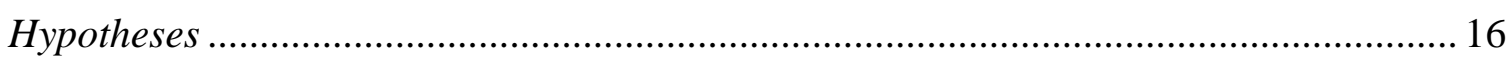

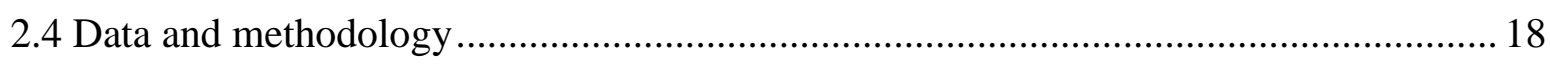

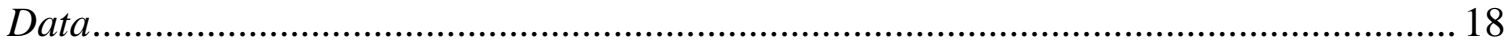

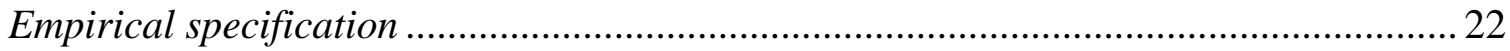

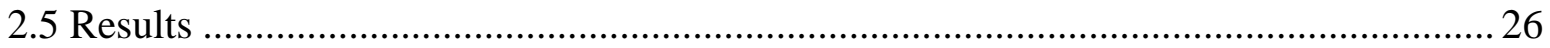

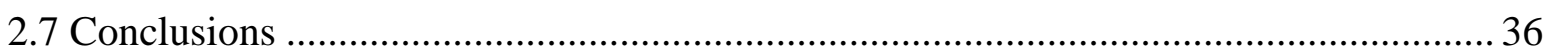

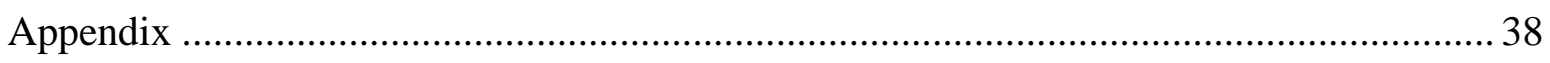

3 Fiji's participation in the global coconut value chain: Opportunities and challenges .......... 41

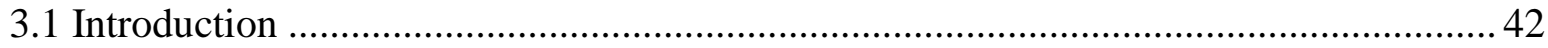

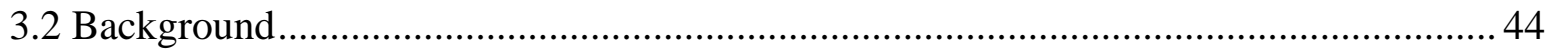

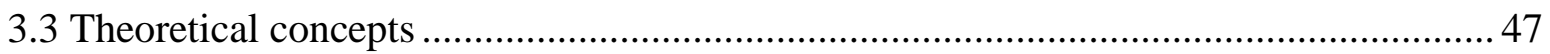

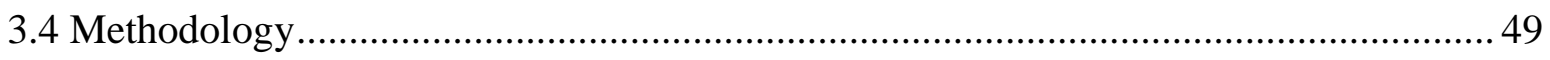

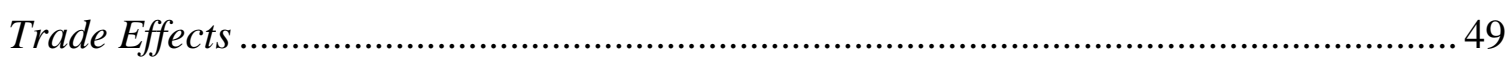

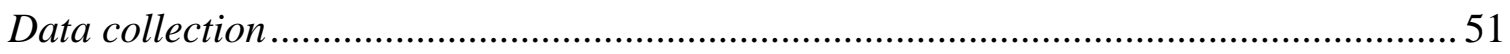

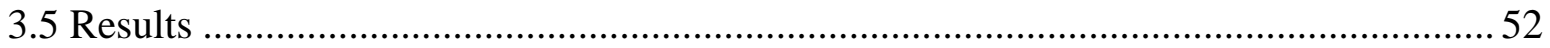

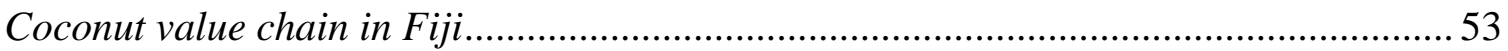

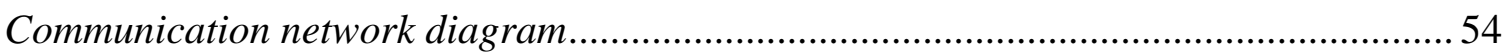

Identifying perceived challenges and opportunities .................................................... 56

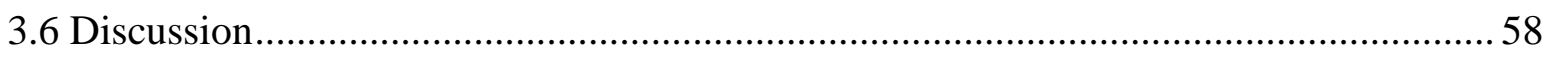

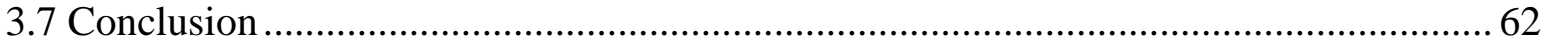


4 Modern agricultural value chains and food security of urban consumers in developing countries

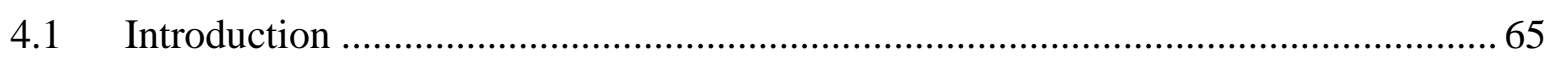

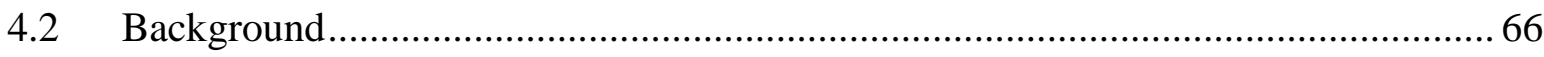

Relative efficiencies of small-scale and commercial agriculture in low-income countries 66

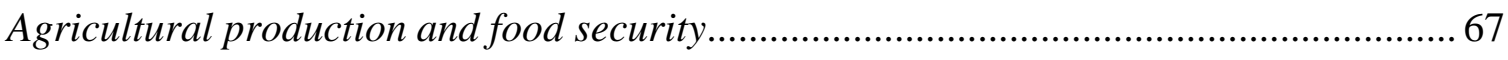

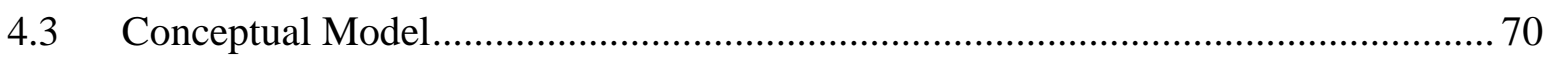

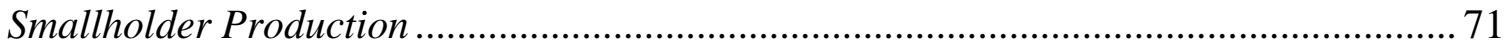

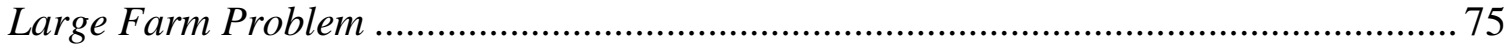

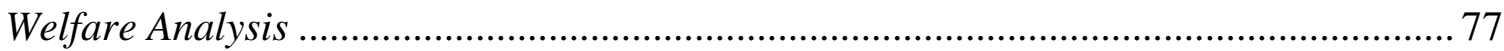

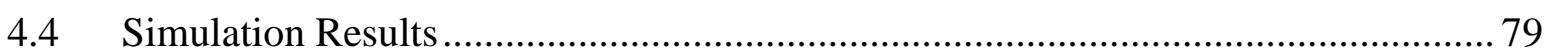

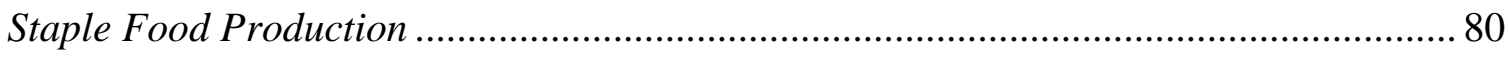

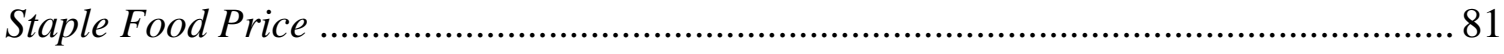

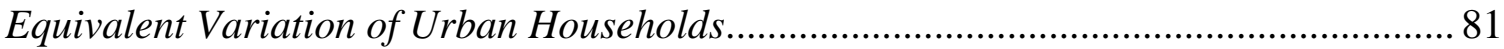

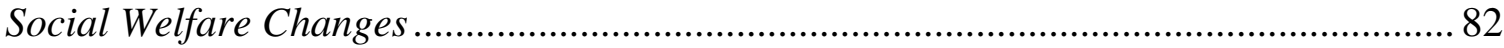

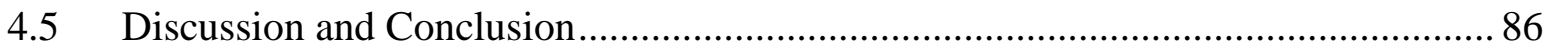

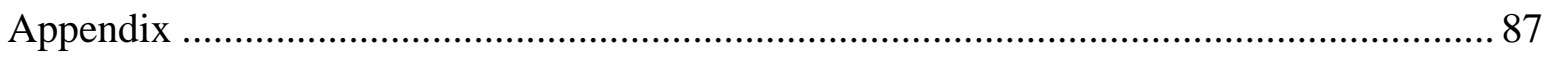

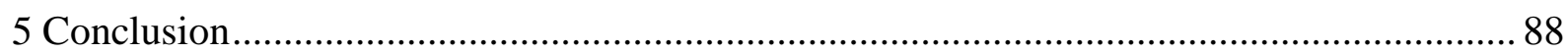

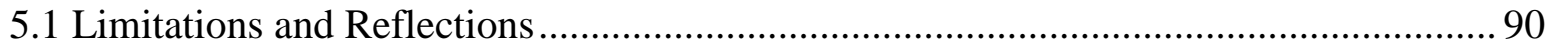

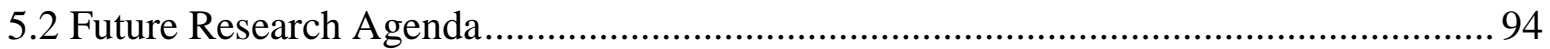

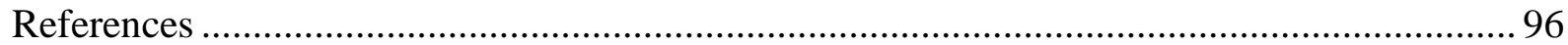

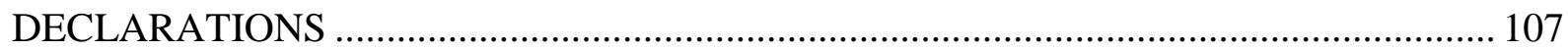




\section{Introduction}

In recent years, the world has seen a transformation of the agrifood industry. In particular, there has been a rise in the integration of agricultural value chains. The importance of high-value agricultural tradeable goods from developing countries has been increasing. For example, the export volumes of these products have increased by $14 \%$ from 1980 to 2010 in South and Southeast Asia, and by $17 \%$ in Latin America (Maertens \& Swinnen, 2015). Combined with trade liberalization, the export market for these products has become more integrated (Gulati et al., 2007). This trend has created opportunities for smallholder farmers and agri-food industries in developing countries through forms of international exchange. Reardon et al. (2003) argue that one of the driving forces for the transformation comes from demand-side aspects, such as increasing income, urbanization, and decreasing transaction costs for consumers due to better infrastructure. Demographic changes and rising incomes throughout the world have an overall effect on the food security status of developing countries. These developments have led to modernized food chains that entail attention to production methods, quality assurance, food safety standards (Maertens et al., 2012).

While smallholder farmers in low-income countries engage in much of the agricultural production, they still face a string of challenges that keep them from participating in opportunities in the market (Bitzer, 2012) Institutions play a role in how well countries integrate throughout this process. There is no shortage of studies that link institutions and development. They range from the relationship between institutions and economic development (Acemoglu et al., 2005; Mauro, 1995), foreign direct investment (FDI) (Daude \& Stein, 2007), productivity (Fulginiti et al., 2004; Lio \& Liu, 2008), trade (Álvarez et al., 2018; Belloc, 2006; Francois \& Manchin, 2013), and participation in global value chains (Dollar \& Kidder, 2017; Kowalski et al., 2015). Past research suggests that small and remote economies can benefit from integrating into global value chains (Breisinger et al., 2019; Kowalski et al., 2015; Streeten, 1993). At the same time, institutions and policies in home countries can hinder this process by implementing distortions such as subsidies.

Some research has focused on the consolidation of modern supply chains driven by the rise of supermarkets (Reardon et al., 2003). Yet, no study looks into the effects of institutional factors on the integration of products with different levels of value-addition. Since high-value agricultural products are increasingly becoming more integrated into global value chains, it is worth looking at the forces that contribute to this growth. 
This dissertation tackles this topic in three different analyses. This is done first on a macro level by analyzing the role of institutions on the trade of coconut products, as presented in chapter 2 . The analysis takes the World Bank's world governance indicators (WGI) and assesses their influence on the export performance of coconut products. The research from chapter 3 involves field studies in Fiji. Qualitative methods are utilized to understand the discourses of farmers involved in coconut farming. Chapter 4 looks into the effects of a transition of rural smallholder farming to selling or renting landholdings and supplying labor to larger commercial farms on the food security and economic welfare of in-country urban consumers. Consistent with the two previous chapters, the importance of institutions is highlighted as institutional forces within the home country contribute to the reasons why smallholder farming persists. We utilize a theoretical model and parameterizes it based on empirical literature to simulate the result of the effects of a transition of rural smallholder farming to selling or renting landholdings and supplying labor to larger commercial farms on the food security and economic welfare in incountry urban consumers. The final chapter concludes and discusses policy implications and limitations in the chapters of the dissertation as well as prospects for future research.

\subsection{Defining institutions}

The concept of institutions can be defined in various manners. For the purpose of this dissertation's analysis, I refer to institutions after North's definition (1991, p. 97) as "the humanly devised constraints that structure political, economic and social interactions". The main concern is in what North (1991) refers to as the "formal rules" of institutions, which are constitutions, laws, and property rights. These formal rules affect the transaction costs that arise during the production of goods and economic exchanges across international borders. According to North and Thomas (1973), the explanation for differences in economic growth lies in institutions. Note that the focus here is not on informal institutions such as social networks, though, their effects cannot be ignored.

The notion of institutions throughout this dissertation is closely linked to that of "governance". Some authors have used the two terms interchangeably (Kaufmann \& Kraay, 2008). Institutions, in this case, is both an economic and political concept. Acemoglu et al. (2005) discuss economic institutions as the foundations of economic growth since they incentivize economic actors, which explains disparities across countries. They also note that economic institutions are implicitly determined by political power because there are competing interests in the distribution of resources which often ends in a zero-sum game. The authors separate between two types of political power, de jure, which is allocated by political institutions, and de facto 
political power, determined by the power given by political institutions in society i.e. the forms of government (Acemoglu et al., 2005). The authors illustrate the importance of political power and economic institutions with the example of North and South Korea post World War II. Despite similar geographical, cultural, and economic features immediately after the colonization of Japan, the split of the two Koreas led to polar opposites in terms of economic growth and political freedom (Acemoglu et al., 2005).

An essential question arises. What constitutes good institutions? Acemoglu et al. (2005) define good "economic" institutions as "those that provide security of property rights and relatively equal access to economic resources to a broad cross-section of society" (p. 395). Anderson and Marcouiller (2002) assert that good institutions have "a legal system capable of enforcing commercial contracts and by transparent and impartial formulation and implementation of government economic policy" (p. 342). Good institutions can enable an environment that encourages economic activities, incentives, growth, and development (Butkiewicz \& Yanikkaya, 2006). Smallholders are often affected by market failures, hence, governments respond by implementing policies that supporting small farms (Birner \& Resnick, 2010). On the other hand, institutions could also contribute to the persistence of smallholder farming by hindering farm consolidation with impeding land transfers and withholding opportunities for off-farm employment.

\subsection{Defining value chains}

This section defines the concepts of value chains, global value chains, and modern agricultural value chains. I then relate the definitions to the analyses in the three chapters of this dissertation. Kaplinsky and Morris' (2001) define value chains as "the full range of activities which are required to bring a product or service from conception, through the different phases of production, delivery to final consumers, and final disposal after use" (Kaplinsky \& Morris, 2001). Value chains are seen as networks that support physical, financial, and informational flows (Angelucci \& Conforti, 2010). Through these flows, smallholders are better supported through market integration and value addition (Angelucci \& Conforti, 2010). As agricultural production becomes more mechanized and capital intensive, the role of value chains has increasingly shifted from primary production to processing and value-adding (Diao et al., 2014; El-Enbaby et al., 2016; Breisinger \& Diao, 2008).

The OECD (2020) defines global value chains to "represent all the activities that take place in transforming raw materials into the product delivered at its end-use" (p. 7). The framework of global value chains takes the traditional value chain concept further by taking in the 
globalization context. In a broader sense, global value chains are connected to a rising level of international trade, global GDP, and employment (Gereffi \& Fernandez-Stark, 2016). The framework seeks to "trace the shifting patterns of global production, link geographically dispersed activities and actors within a single industry, and determine the roles they play..." (Gereffi \& Fernandez-Stark, 2016, p. 6). In agriculture, the concept revolves around connecting local farmers or producers from developing countries to global markets, linking raw-material producers to end-users (Dijk \& Trienekens, 2012).

Finally, the concept of modern agricultural value chains is essential to this dissertation. In line with Henderson and Isaac (2017), I argue that the modernization of agricultural value chains in developing countries can be attributed to forces on both the demand and supply side. These include forms of foreign direct investments in retail and processing, and requirements in food quality and safety standards (Maertens et al., 2012). One important catalyst for change is urbanization and its effects on flows of agricultural production where farmers are becoming increasingly dependent on supplying to urban food markets (Minten et al., 2017). Another is the increase in trade of high-value commodities.

\subsection{Linking institutions to global and modern agricultural value chains}

According to Kowalski et al. (2015 p. 13), the determinants of countries' integration into the global value chain are "the origin of the value-added embodied in exports both looking backward and forward from a reference country: backward when it comes to foreign valueadded embodied in exports and forward when it refers to domestic value added which is used as inputs to produce exports in the destination country." Important mechanisms that stimulate participation in the global value chain include market size, level of development, industrial structure, location, trade policies, logistics performance, and quality of institutions (Kowalski et al., 2015). Gereffi and Fernandez-Stark (2016) introduce a model that includes four pillars that can better integrate small producers: access to market, access to training, collaboration and cooperation building, and access to finance.

Transaction costs and contract enforcement play an important role when assessing the relationship between institutional quality and participation in global value chains. Institutions affect integration by facilitating contractual agreements at different stages along a value chain (Martincus \& Gallo, 2009). As products become more complex, the need for legal institutions also increases due to information asymmetry and the lack of protection and credible enforcement (Dollar \& Kidder, 2017). According to Costinot (2009), as a firm expands as a 
result of specialization, more workers are needed, thus results in more contracts that need to be enforced.

More explicitly, governments can impose tariffs or sign trade agreements that could either reduce or increase a firm's competitiveness in the global market (Kowalski et al., 2015). Cross border trade involves transaction costs during the retail and export level, including transportation cost, border efficiency, and delivery time (Nordas \& Piermartini, 2004). Furthermore, infrastructure, the business environment, and other non-tariff measures can affect integration into global value chains.

Institutions play a central role in creating an enabling environment via domestic policies to determine a country's agricultural competitiveness (OECD, 2020). This means that institutional quality influences whether countries only export low-value-added products, or whether they can integrate into more complex value chains (Dollar \& Kidder, 2017), particularly for countries with relatively similar levels of skilled labor and overall capital. On the other hand, distortions enabled by institutions can impede the creation of value within a global value chain (OECD, 2020).

One of the reasons for the persistence of smallholder farming is influenced by negative and positive domestic institutional forces (Ma \& Sexton, forthcoming). In many countries around the world, institutions impede communal land transfers to assure egalitarian outcomes (Gottlieb \& Grobovšek, 2019). Smallholder farming has received much institutional support due to some evidence that highlights the importance of smallholder farms if agriculture is to play a role in development and poverty reduction (Birner \& Resnick, 2010; Diao et al., 2007). For example, governments in many Asian and African countries have committed resources to small farmers, such as technical assistance, income transfers, and trade protection (Hazell et al., 2010).

\subsection{Summaries of essays}

The main takeaway from this thesis is that institutions matter through different mechanisms and on both a macro and micro-level.

The first paper, presented in chapter 2, is co-authored with Insa Flachsbarth and Stephan von Cramon-Taubadel with the title "The role of institutional quality on the performance in the export of coconut products ${ }^{1}$ ". Existing literature on institutional quality and export performance only assessed trade in general, or in certain aggregate sectors (Álvarez et al., 2018; Bojnec \& Ferto, 2015; Meon \& Sekkat, 2008). Product-specific studies are lacking. Our study is a first attempt to close this literature gap by considering institutional and product heterogeneities. This

\footnotetext{
${ }^{1}$ This paper is published in Agricultural Economics
} 
chapter aims to answer three research questions. First, we are interested in how the overall institutional environment in exporting countries affects the bilateral trade of coconut products. Second, we look into whether improvements in each of the exporters' indicator scores lead to an increase in trade with consideration to the exporters' and importers' overall institutional setting. Lastly, we investigate the effects of institutional similarities for coconut trade and its different compositions of value addition. To address these questions, we utilize structural gravity models to measure how institutional quality affects the trade performance of the top 26 coconut producing countries to the top 15 importing economies over the span of 20 years. Our results suggest that increased government effectiveness enhances trade of high-value products, whereas better voice and accountability scores decrease the trade of coconut products in both categories of value addition.

Chapter 3 investigates the challenges and opportunities of a small island nation's integration into the global value chain with an emphasis on the role of institutions titled "Fiji's participation in the global coconut value chain: Opportunities and constraints ${ }^{2}$ ". First, I assess on a macrolevel at the link between institutional quality and Fiji's export of coconut products. Then, I look in-depth by conducting semi-structured interviews with stakeholder groups in different regions of Fiji to gain an understanding of the perceived challenges and opportunities in the coconut sector. The empirical results show that increased scores in the government's effectiveness and voice and accountability indicators enhance coconut exports from Fiji, suggesting that domestic institutions play an important role. Interviews with key actors reveal that communications among each stakeholder group are fragmented. The main institutional actors and the producers have different perceptions of the industry's challenges, thus resulting in different ideas on how to address the issues.

The fourth chapter of my dissertation is a collaboration stemmed from my research stay at the University of California Davis. This study, co-authored with Meilin Ma and Richard Sexton, titled "Modern agricultural value chains and food security of urban consumers in developing countries", builds on previous research (Ma \& Sexton, forthcoming) that assesses the future of smallholder farming systems in modern agricultural value chains. Their results suggest that even considering labor-efficiency advantage, smallholder farms are more likely to encounter challenges in selling price and access to market inputs. This study aims to evaluate the effects of a transition of rural smallholder farming to selling or tenting landholdings and supplying labor to larger commercial farms on the food security and economic welfare in in-country urban consumers. We obtain price elasticities of demand for staple food commodities in developing

\footnotetext{
${ }^{2}$ This paper is published in the Journal of Agribusiness in Developing and Emerging Economies
} 
countries from 15 peer-reviewed articles. Based on these figures, we embed a demand-side framework into the Ma-Sexton model to study the effects of land consolidation and the advent of commercial farming systems on the economic welfare of smallholder farmers and home country urban consumers. Staple food consumption and smallholder utilities are compared under the two scenarios. The simulation results show that compared to smallholder farming, a transition to commercial operations leads to larger quantities of staple food produced. Both rural and urban households pay lower prices for staples, enabling them to use the extra netincome to consume other goods, resulting in an increase in overall welfare. 


\title{
2 The role of institutional quality on the performance in the export of coconut products
}

\begin{abstract}
The literature that addresses the role of institutions in bilateral trade is extensive. However, research that links institutional quality to specific products and their different levels of value addition is lacking. In this study, we look into institutional quality, based on three indicators from the World Bank, and its indicator-specific effects on bilateral coconut trade. In particular, we study coconut products with varying degrees of value-addition. We utilize structural gravity models to measure how institutions affect the trade performance of the top 26 coconut producing countries to the top 15 importing economies over the years 1996-2016. Our results suggest that increased government effectiveness enhances trade of high-value products, while better voice and accountability scores decrease trade of coconut products with both levels of value addition. No clear trade effect is observed when two countries are more similar in each of the three indicators. We conclude that each indicator has different trade effects on each of the coconut product categories. We end by giving recommendations that will help to improve the coconut export performance in their respective countries and for future research.
\end{abstract}

Keywords: Coconut trade, gravity model, institutional quality, value-added

JEL Classifications : F14, Q17, Q18, P48

This paper is now published in Agricultural Economics. The co-authors of this chapter are Insa Flachsbarth (IF) and Stephan von Cramon-Taubadel (SCT). The contributions of each author are as follows: Jessie Lin (JL) and SCT conceptualized the research. Data was gathered and compiled by JL. JL analyzed and interpreted the data. IF and SCT assisted in the analysis and interpretation of the results. The writing was done by JL with the assistance of IF. IF and SCT provided invaluable feedback and comments at different stages of the research and drafting of the paper.

Acknowledgments: I would like to acknowledge Dela-Dem Fiankor, Eva Hasiner, and Hendrik Kruse for assisting and sharing in-depth knowledge of the components of the gravity model. I would also like to thank Prof. Bernhard Bruemmer for giving me valuable suggestions and feedback. 


\subsection{Introduction}

In the last few decades, agricultural value chains have become more and more internationally integrated due to advancements in technology, reduction in transportation costs, and market liberalization (Degain \& Maurer, 2015). These global trends have altered the agricultural industry and increased trade in many countries over the past few decades. This process is supported by a wide range of outward-looking policies, such as a reduction in tariffs, marketdetermined exchange rate regimes, and more generally, measures to deregulate and facilitate international trade. Together, this has generated opportunities for export sectors, especially in developing and emerging economies (Gulati et al., 2007). In particular, the production and trade of non-traditional and high-value export commodities have increased (Gulati et al., 2007; Maertens et al., 2009; O'Connell et al., 2008). Given that poorer countries often depend heavily on agriculture, improving market access to such high-value chains can be of great relevance for their development paths.

The trade literature has only recently begun to focus on the role of domestic governance and institutional influences in the development of high-value agricultural supply chains. Studies by Bojnec and Fertö (2009) and Mendonça et al. (2014) suggest that good governance leads to an increase in agricultural trade as a result of lower transaction costs and thus facilitates access to high-value agricultural markets. In other words, institutions can foster the transformation of countries that traditionally have traded low-value primary products into exporters of high-value food products.

Coconut is an interesting and relevant commodity to study for a number of reasons. For many coconut-producing countries, particularly small Pacific Island countries, the production and trade of this commodity support the livelihoods of large parts of the rural population. International coconut trade used to be driven by demand for coconut oil (Prades et al., 2016), but this has changed in recent decades. Coconuts are increasingly being transformed into highvalue products that require more complex processing throughout export-oriented value chains. This move to high-value-added products is in part driven by marketing strategies that brand coconut products as healthy alternatives for hydration and cooking. Since most coconuts are grown by poor farmers who have few resources (Naresh et al., 2013), and institutional quality tends to be traditionally lower in coconut producing countries than the predominant importing economies, it is crucial to look at the role of institutions in the different channels that affect coconut trade. 
The growing literature on the role of institutions in international trade has not focused on individual high-value commodities and the effects of specific institutional variables. We fill this gap by differentiating between categories of coconut products, characterized by more or less value addition, and how they are affected by different dimensions of institutions in a given institutional setting. This allows us to consider product-specific heterogeneities when evaluating the effect of each institutional indicator on exports.

We seek to answer the following research questions:

R1. How does the overall institutional environment in exporting countries affect bilateral trade of coconut products?

R2. Do improvements in the exporters' individual indicator scores lead to enhanced trade depending on the exporters' and the importers' overall institutional setting?

R3. What are the effects of institutional similarities for coconut trade and its compositions? In our empirical analysis, we study the influence of institutions on the export performance of coconut products from the top 26 coconut producing countries ${ }^{3}$ to the top 15 coconut importing regions. We measure export performance as the actual volume of exports. We utilize the World Bank's world governance indicators developed by Kaufmann et al. (1999) as measures of domestic institutions and apply them in a structural gravity model framework. We first look at how the overall institutional structure of a producing country affects coconut trade. In addition, we take three out of the six indicators (voice and accountability, government effectiveness, and control of corruption) to assess the influence of each indicator on trade. We expect that each indicator within the institutional structure will affect coconut trade. For instance, corruption could impede trade due to the reduction of domestic investments (Mauro, 1995), while voice and accountability could lower trade due to the increased bargaining power of workers (Berden et al., 2014). However, we also expect these effects to vary across high-value and low-value coconut products.

The structure of this paper is as follows. Section two reviews past literature on the linkages between institutions in international trade. Section three presents the theoretical framework that guides our research. Section four details the data collection method and the estimation strategy that we use in this study. Section five presents our results followed by a discussion and policy recommendations. Finally, section six concludes.

\footnotetext{
${ }^{3}$ These 26 countries make up almost the entire global trade at $95 \%$ of the total world trade.
} 


\subsection{Literature review}

This section gives an overview of existing literature on the linkages between institutional quality and international trade. We define institutions after North (1991, p. 97) as "the humanly devised constraints that structure political, economic and social interactions". We are interested in what North (1991) calls the "formal rules" of institutions, which are constitutions, laws, and property rights. These formal rules affect the transaction costs that arise during the production of goods and economic exchanges across international borders. In this study, we associate domestic institutions to influence the different processes and actors involved from the production to the export of coconut products. Transaction costs affect this supply chain via the transaction effect and the production effect (Belloc, 2006; Berkowitz et al., 2006; Iwanow \& Kirkpatrick, 2009).

While definitions such as North's are widely accepted, measuring institutional quality is a difficult undertaking. We utilize the World Bank's world governance indicators as measures of institutions. There are several other indexes of institutional quality. The Fraser Institute, the Heritage Foundation, and World Economic Forum all publish an index to measure countries' degrees of economic freedom. Transparency International rates countries on their ability to control corruption in their corruption perceptions index. Since none of these indexes fully captures the different dimensions of what we define as "institutions", we find the World Bank's indicators as the most suitable for the purposes of this study.

We follow previous studies by categorizing the six indicators into three dimensions (Berden et al., 2014; Lio \& Hu, 2009; Lio \& Liu, 2008; Méon \& Weill, 2005). Each dimension includes two indicators that measure the same aspects of governance. As outlined in the Methodology section below, we use one indicator from each of the three dimensions as our institutional variables.

Table 2.1 summarizes the main findings of selected studies on the subject. These studies confirm that governance and institutions contribute to explaining trade flows. We define good institutions after Anderson and Marcouiller (2002) as one with "a legal system capable of enforcing commercial contracts and by transparent and impartial formulation and implementation of government economic policy" (p. 342). The effect of bad institutions can be seen as a tariff which increases the cost of business (Daude \& Stein, 2007). In addition, a bad institutional environment raises uncertainty during contract enforcement (de Groot et al., 2004). 
Table 2.1: Summary of findings on institutional quality and international trade ${ }^{4}$

\begin{tabular}{|c|c|c|}
\hline References & Indicators Utilized & Main Findings \\
\hline $\begin{array}{l}\text { Anderson and Marcouiller } \\
\text { (1999) }\end{array}$ & Contract enforcement & $\begin{array}{l}\text { Competent institutions can } \\
\text { increase trade with contract } \\
\text { enforcement by legal systems. }\end{array}$ \\
\hline De Groot et al. (2004) & Aggregates of six indicators & $\begin{array}{l}\text { High institutional quality } \\
\text { decreases transaction costs } \\
\text { thus positively influences trade } \\
\text { flows. }\end{array}$ \\
\hline Meon and Sekkat (2008) & Aggregates of six indicators & $\begin{array}{l}\text { Good governance indicators } \\
\text { increase exports of } \\
\text { manufactured goods, but not in } \\
\text { non-manufactured products. }\end{array}$ \\
\hline Bojnec and Fertő (2009) & $\begin{array}{l}\text { Importer-exporter-similarity of } \\
\text { aggregates of six indicators }\end{array}$ & $\begin{array}{l}\text { Similarities in institutional } \\
\text { quality increase agricultural } \\
\text { trade due to lower transaction } \\
\text { costs. }\end{array}$ \\
\hline Francois and Manchin (2013) & Aggregates of six indicators & $\begin{array}{l}\text { Domestic institutions can } \\
\text { boost exports due to increased } \\
\text { international market access. }\end{array}$ \\
\hline Mendonça et al. (2014) & $\begin{array}{l}\text { Importer-exporter-similarity of } \\
\text { aggregates of six indicators }\end{array}$ & $\begin{array}{l}\text { Differences in institutional } \\
\text { environments between trading } \\
\text { partners decrease trade flows } \\
\text { due to increased transaction } \\
\text { costs }\end{array}$ \\
\hline $\begin{array}{l}\text { Martínez-Zarzoso and } \\
\text { Márquez-Ramos (2018) }\end{array}$ & $\begin{array}{l}\text { Political stability, rule of law, } \\
\text { and control of corruption }\end{array}$ & $\begin{array}{l}\text { Increased scores in political } \\
\text { stability, rule of law, and } \\
\text { control of corruption in } \\
\text { exporting countries increase } \\
\text { trade. }\end{array}$ \\
\hline
\end{tabular}

Anderson and Marcouiller (1999) argue that inadequate contract enforcement can be seen as a form of insecurity that introduces hidden transaction costs in international exchange. With good institutions in place, nations have jurisdiction not only to enforce contracts but also to implement trade agreements (Rodrik, 2000). Countries with better institutional quality are able to facilitate long-term contracts and agreements at different stages along the value chain which allows for increased exports in products with more complex processing (Martincus \& Gallo, 2009). Amiri et al. (2019) find that in countries with both good institutional quality and rich

\footnotetext{
4 "Indicators utilized" column specifies the indicators or type of institutions that each authors assessed. Aggregates of six indicators refers to either an average or sum of the six World Bank's world governance indicators. All studies in the table used forms of the gravity model as their methodology.
} 
natural endowments, rents can lead to a promotion in the manufacturing sector. De Groot et al. (2004) confirm that increased institutional quality is able to decrease ambiguity regarding contract enforcement and the governance of overall economics.

Institutional similarities between two countries can familiarize stakeholders with the procedures involved during the process of exchange (de Groot et al., 2004). Bojnec and Ferto (2009) confirm that international trade increases as a result of lower transaction costs when institutions are similar. Two countries might score poorly on political freedom, but this may facilitate trade between them since two autocratic regimes might have similar standards and behavior during bilateral exchange (Bojnec \& Ferto, 2015). Furthermore, differences in institutional quality between two trading countries can reduce trade due to higher transaction costs between the two sides (Mendonça et al., 2014).

Many studies have shown that institutional quality is positively associated with trade on an aggregate level (Álvarez et al., 2018; Anderson \& Marcouiller, 2002; Francois \& Manchin, 2013). Studies using different institutional indicators show positive influences on the economy. Meon and Sekkat (2008) find that governance indicators are positively associated with exports of manufactured goods. Yu (2010) finds that democratization can lead to a three to four percent growth in bilateral trade. Abe and Wilson (2008) find that trade in the Asia and Pacific region increases with reductions in corruption and increased transparency. Research by Duc et al. (2008) shows that countries with higher levels of corruption trade less with each other. Martincus and Gallo (2009) find with increased institutional quality, countries have a comparative advantage at trading in sectors that produce more institutional-intensive goods.

Institutions may not affect export performance equally across sectors. For example, corruption may smooth the export process in sectors such as oil and gas (Meon \& Sekkat, 2008). Institutions seem to influence manufactured goods and non-manufactured goods differently, as Meon and Sekkat (2008) find no significant relationship between non-manufactured products and governance indicators. Martincus and Gallo (2009) find that better institutional quality leads to increased export of goods with production processes that are of higher complexity. Furthermore, not every aspect of governance is conducive to trade. For example, Berden et al., (2014) find that a rise in pluralism decreases trade flows due to the increasing bargaining power of workers. Aside from the effects of institutions, Yang et al. (2018) note the reliance on social networks and informal relationships in supply chain relationships when formal institutions fail to facilitate contract enforcement. 
The studies to date have generated many interesting insights, but they have not specifically addressed the different dimensions of institutions and their effect on the composition of valueadded trade within a specific agricultural product group. We intend to fill this gap by analyzing the relationship between various aspects of institutional quality and the trade of different coconut products with differing levels of value addition.

\subsection{Conceptual Framework}

\section{Theoretical concepts}

Our empirical analyses draw on the World Bank's world governance indicators. We first assess the institutional environment as a whole by averaging the six indicators from the World Bank. We then utilize three out of the six indicators to measure their specific influences. Figure 2.1 presents the conceptual framework that guides our study. The framework refers to the coconut sector and addresses the actors and steps involved throughout the coconut supply chain.

Figure 2.1: Conceptual framework, author's illustration

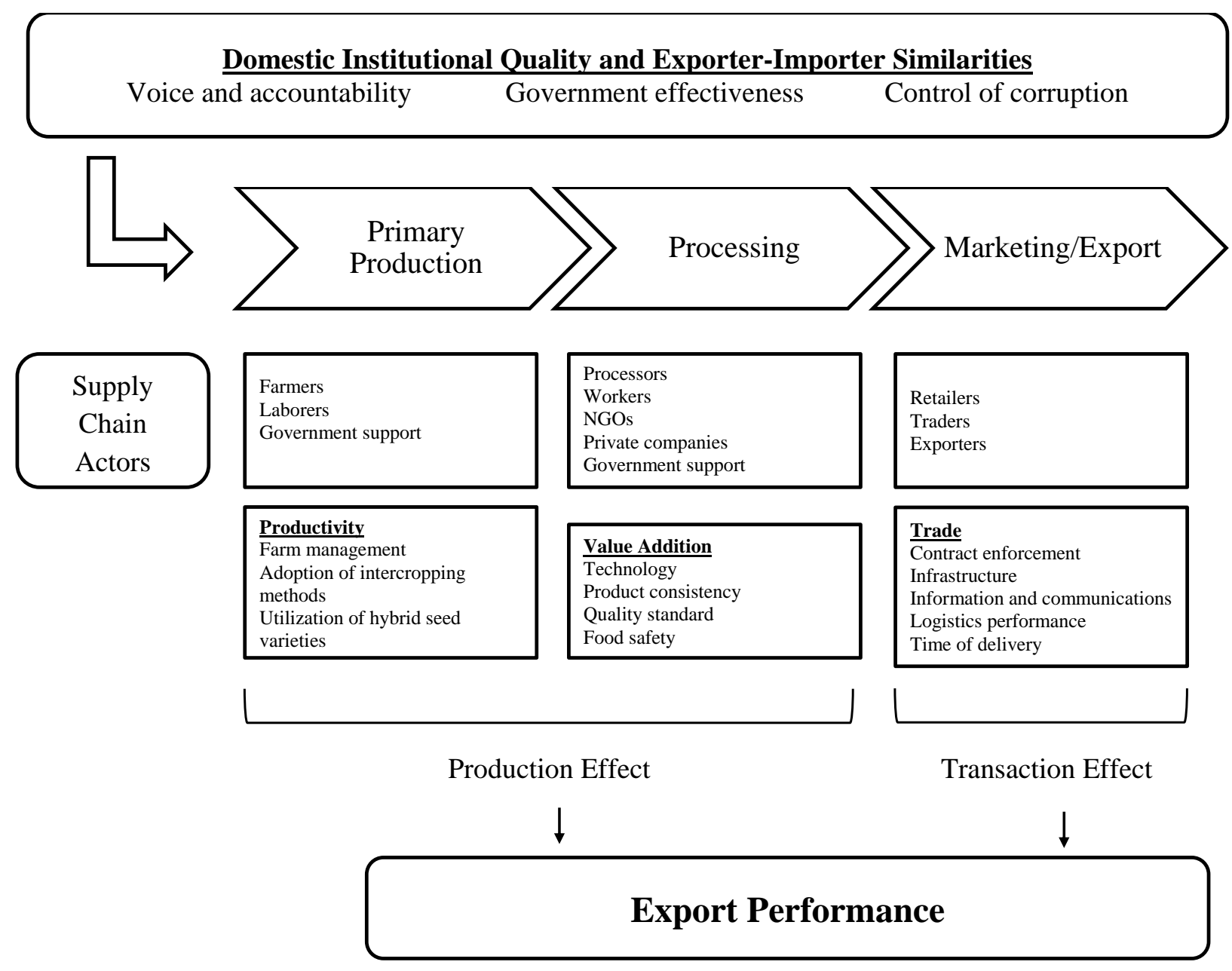


We assess the production and processing aspects of the coconut supply chain through the lens of the production effect. As coconut products go through value addition, the factors and processes of production involve more steps and higher production costs, as suggested by Berkowitz et al. (2006). In order to produce an export product, the processing stage needs to ensure quality standards, such as product consistency, packaging, and safety. For example, the packaging of coconut water exported to the European Union (EU) must preserve the color and taste of the original product. Furthermore, the product must be free from bacteria and other contamination (Centre for the Promotion of Imports, 2016). Countries with lower institution quality may not be able to fulfill these requirements and end up exporting only primary and raw commodities (Martincus \& Gallo, 2009). These countries could also fail to innovate in the production of niche items due to the lack of complementary services and technology to develop them (Martincus \& Gallo, 2009).

The production effect influences the production stage of raw coconut materials. It is estimated that around $85 \%$ of smallholders across the world still practice traditional nursery methods (Johnson \& Bourdeix, 2014). Furthermore, many coconut palms are becoming senile in producing countries (FAO, 2013). Smallholder farmers need institutional support related to replanting strategies and access to seedling varieties to ensure the productivity of the palms.

Institutional quality affects international trade through the "transaction effect", which involves the processes on the retail and export level. International transaction costs can be referred to as any type of cost that is incurred during trade; they include transportation costs, costs to enter and enforce contracts, border efficiency, and delivery time (Nordas \& Piermartini, 2004). The gap in legal and political systems increases the chance of cheating during bilateral exchange (Belloc, 2006). When insecurities arise during the negotiation and enforcement stages of trade, they can act as a price premium on the traded good, resulting in less trade (Anderson \& Marcouiller, 2002; den Butter \& Mosch, 2003). During the marketing and exporting stage of the supply chain, adequate infrastructure is crucial to determine the delivery time of the final items.

The described production and transaction effects of varying degrees of institutional quality are embedded into the theoretical assumptions of the gravity model that is chosen for the empirical estimation strategy in the study (see Section 4.2). The gravity model seeks to explain bilateral flows by incorporating demand and supply as well as the different relative trade costs. Following our line of thought above, institutional quality changes translate into supply changes through the production effect and trade cost changes via the transaction effect. Thus, the gravity 
model fits into our conceptual framework by capturing the aspects of institutional quality along different degrees of value addition with their trade effects.

\section{Hypotheses}

We define each of the institutional indicators in table 2.2, and subsequently, hypothesize their anticipated effects on bilateral trade given our conceptual framework. By looking at these indicators we answer our research question of the type of institutions that are relevant for different types of coconut products.

Specifically, we test the following hypotheses. H1 seeks to answer R1; H2 to H4 correspond with R2; lastly, R3 is addressed by H5.

Table 2.2: World Bank's world governance index and definitions

\begin{tabular}{ll}
\hline Indicator & Definition \\
\hline Voice and accountability & $\begin{array}{l}\text { Voice and accountability: the extent to which a country's citizens } \\
\text { are able to participate in the selection of their government, as well } \\
\text { as freedom of expression, freedom of association, and free media. }\end{array}$ \\
Government effectiveness & $\begin{array}{l}\text { Government effectiveness: the quality of public services, the } \\
\text { quality of the civil service and the degree of its independence from } \\
\text { political pressures, the quality of policy formulation and } \\
\text { implementation, and the credibility of the government's } \\
\text { commitment to such policies. }\end{array}$ \\
Control of corruption & $\begin{array}{l}\text { Control of corruption, which is defined as the extent to which } \\
\text { public power is exercised for private gain. }\end{array}$ \\
\hline
\end{tabular}

Source: Kaufmann et al. (2009)

H1: A good overall institutional environment in producing countries increases bilateral trade due to its ability to shape countries' comparative advantage in goods with different degrees of complexity.

H2: Voice and accountability has a negative effect on bilateral trade flows of high-value coconut products as the increase of the bargaining power of workers undermines the level of cooperation needed in complex processing and value-added activities.

The first indicator, "voice and accountability", assesses a country's procedure for selecting a government and keeping it in check (Berden et al., 2014). Berden et al. (2014) contend that voice and accountability is most related to pluralism. Pluralism increases the voice and bargaining power of unskilled laborers, which could lead to a decrease in foreign investment (Berden et al., 2014). Li and Resnick (2003) suggest that pluralism could decrease the degree of cooperation in producing countries. We link this indicator to the production and processing stage in our conceptual framework. Following these authors, we hypothesize that increased voice and accountability negatively affects the international trade of high-value coconut 
products as the increase of bargaining power of workers undermines the level of cooperation needed in more complex processing and value-addition within the country.

H3: Government effectiveness increases bilateral trade flows of both lower-and higher-value products due to contract enforcement and monitoring.

The second indicator "government effectiveness" measures the government's ability "to effectively formulate and implement sound policies" (Kaufmann et al., 2009, p. 6). This indicator captures whether institutions are able to deliver complementary services during the production of coconuts and the enforcement of contracts during bilateral exchange. We expect increased government effectiveness to have a positive effect on all three stages of the supply chain. It facilitates the complementary goods and services needed to process coconut products. Furthermore, it can increase exports of all types of coconut products due to increased ability to enforce and monitor the stages of processing. We hypothesize that this indicator will have a bigger effect on high-value products since it is more challenging to enforce contracts during the trade of more complex products (Berkowitz et al., 2006).

H4: Control of corruption increases bilateral trade flows of both product categories as it facilitates economic interactions and increases trust between exporting and importing countries.

The indicator "control of corruption" measures the extent to which the government respects its citizens and the rules of society (Kaufmann et al., 2009). Better control of corruption means that courts within a country are able to exercise impartiality and handle cases without any biased influence in the court's final decision (Berkowitz et al., 2006). High levels of corruption hinder international trade by lowering productivity and especially the quality of customs services (Ben Ali \& Mdhillat, 2015). We expect that entry points for corruption occur through the more complex stages of processing coconuts. Furthermore, if a country is known to be corrupt, then importing countries are less certain that products will fulfill the indicated quality and standards. We anticipate that easing corruption leads to better performance in all coconut exports, with the effect to be larger for high-value than for low-value products.

H5: Similarities in all three above indicators lead to increased trade between two countries due to familiar procedures in bureaucratic procedures involved during both the production and transaction process. ${ }^{5}$

Lastly, we expect institutional similarities in all three indicators to be positively associated with bilateral trade. Institutional similarity reduces the adjustment costs that arise from dissimilar

\footnotetext{
${ }^{5} \mathrm{H} 5$ intends to address whether institutional similarities positively or negatively affect bilateral trade, but not in the magnitude of trade.
} 
procedures and insecurities during bilateral trade (Linders et al., 2005). In addition, the nature of doing business in two countries could refer to ethical standards; if bribing officials is considered acceptable in two countries, then bribes might facilitate trade between both (Horsewood \& Voicu, 2012).

\subsection{Data and methodology}

\section{Data}

To estimate the determinants of bilateral trade flows in coconut products, we gathered trade data and proxies for trade costs from various sources for the years 1996-2016. Reasons for using the specific data in our framework are explained in detail in section 4.2. We obtain bilateral coconut trade data from the United Nations Commodity Trade (UNComtrade) database, via the World Integrated Trading System (WITS). We use data on import values by the 15 largest importers of coconut products from the top 26 coconut producing countries measured in US Dollars. Import data is considered more reliable since governments have higher incentives to track imports for tax purposes (Francois \& Manchin, 2013). Table 2.3 shows a list of the top coconut producing countries in 2016, expressed in metric tons, and their trade value in 1000 US Dollars.

Table 2.3: Main coconut producing countries in 2016 with production quantity in tons and trade value in 1000 US dollars

\begin{tabular}{lrr}
\hline Country & Production (MT) & $\begin{array}{r}\text { Export } \\
\text { (in 1000\$) }\end{array}$ \\
\hline Indonesia & $17,722,429$ & $1,287,991.00$ \\
Philippines & $13,825,080$ & $1,861,631.00$ \\
India & $11,127,898$ & $281,608.20$ \\
Brazil & $2,649,246$ & $72,579.08$ \\
Sri Lanka & $2,520,095$ & $353,524.00$ \\
Vietnam & $1,469,960$ & $318,745.30$ \\
Papua New Guinea & $1,191,438$ & $88,386.06$ \\
Mexico & $1,157,481$ & $191,344.50$ \\
Thailand & 815,406 & $1,069,091.00$ \\
Tanzania & 555,836 & $2,359.12$ \\
Myanmar & 531,730 & $27,855.91$ \\
Malaysia & 504,773 & $473,522.60$ \\
Kiribati & 437,000 & $2,106.76$ \\
Ghana & 380,380 & $8,751.75$ \\
Dominican Republic & 374,474 & $19,920.63$ \\
Solomon Islands & 341,876 & $16,908.75$ \\
Vanuatu & 336,988 & $15,183.71$ \\
China & 316,579 & $732,289.60$ \\
Nigeria & 283,744 & $2,068.85$ \\
Jamaica & 255,411 & $8,454.77$
\end{tabular}




\begin{tabular}{lrr} 
Mozambique & 248,394 & $6,816.43$ \\
Fiji & 206,393 & $5,584.58$ \\
Samoa & 179,602 & 555.34 \\
Venezuela & 157,391 & $1,172.44$ \\
Cote d'Ivoire & 142,923 & $27,886.03$ \\
Marshall Islands & 253,06 & $1,719.99$ \\
\hline
\end{tabular}

Source: FAOSTAT

We consider three categories of coconut products as shown in table 2.4. The first category includes high-value coconut products, which we assume are required to meet higher quality expectations of importing countries. These products are likely to be edible items that must fulfill exacting quality and traceability standards. The "low-value" products in the second category do not need to meet such exacting criteria. Finally, coconut oil is in its own category due to its dominance in coconut exports. In the year 2017/2018, the global export volume was around 1.7 million metric tons (USDA, 2018).

Table 2.4: Coconut product categories ${ }^{6}$

\begin{tabular}{ll}
\hline Categories & Products included \\
\hline High-value products & $\begin{array}{l}\text { Fresh and/or dried coconuts, coconut milk, activated carbon and } \\
\text { coconut water }\end{array}$ \\
Low-value products & Copra, coir, and oilcake \\
Coconut Oil & All types of oil \\
\hline
\end{tabular}

Traded items are only published on the UN Comtrade database up to six-digit Harmonized System (HS) codes. Coconut milk, coconut water, and activated carbon from coconuts are all traded in eight-digit HS codes which are not documented in the database. For this reason, we take up six-digit codes reported by UN Comtrade.

As outlined above, we use the World Bank's world governance indicators from the years 1996 to 2016 to measure institutional quality. The World Bank published the indicators bi-yearly from 1996 to 2002, and annually since then. For the years 1997, 1999, and 2001, we use the values from the previous year. The World Bank's world governance index is one of the most recognized and referenced indicators in research. It is based on hundreds of variables created by 33 international organizations (Kaufmann et al., 2009). The six indicators are scaled from 2.5 to 2.5. Higher values correspond to better governance, and zero is the median score. We then select one indicator from each of the three dimensions mentioned in our conceptual framework: voice and accountability, government effectiveness, and control of corruption and measured its effects separately in both exporting and importing countries according to their

\footnotetext{
${ }^{6}$ See table A2.4 for detailed product HS codes and their average unit values
} 
institutional setting. Table 2.5 shows exporters and importers with either positive or negative average indicator scores.

Since the indicators are themselves correlated, each indicator could affect trade directly or indirectly by its influence on the other indicators (Lio \& Liu, 2008). For this reason, we choose one from each dimension to avoid the possible correlation between the two indicators. Despite their great advantage of comparability at the global scale, these indicators do have certain weaknesses. Thomas (2010) asserts that the concepts of each indicator are not clearly defined. Furthermore, the definitions are not based on any theory, nor are they consistent with the existing literature (Thomas, 2010). Langbein and Knack (2010) contend that it is difficult to distinguish one indicator from another since each is represented by different concepts. Nevertheless, the index includes a wide sample of countries including almost all countries of interest in this study.

Table 2.5: Exporters and importers by positive and negative average indicator categories

\begin{tabular}{|c|c|c|}
\hline Country Groups & $\begin{array}{l}\text { Positive } \\
\text { indicators }\end{array}$ & Negative average indicators \\
\hline Exporters & $\begin{array}{l}\text { Brazil, Kiribati, Jamaica, } \\
\text { Kiribati, Malaysia, Vanuatu }\end{array}$ & $\begin{array}{l}\text { China, Côte d'Ivoire, Dominican } \\
\text { Republic, Fiji, Ghana, India, Indonesia, } \\
\text { Marshall Islands, Mexico, Mozambique, } \\
\text { Myanmar, Nigeria, Papua New Guinea, } \\
\text { the Philippines, Samoa, Solomon Islands, } \\
\text { Sri Lanka, Tanzania, Thailand, } \\
\text { Venezuela, Vietnam }\end{array}$ \\
\hline Importers & $\begin{array}{l}\text { Australia, Canada, Hong } \\
\text { Kong, Japan, Korea, } \\
\text { Malaysia, Singapore, } \\
\text { United States, EU } 27\end{array}$ & $\begin{array}{l}\text { China, Indonesia, Laos, the Philippines, } \\
\text { Russia, Thailand }\end{array}$ \\
\hline
\end{tabular}

Despite their shortcomings, these indicators are considered to be one of the best existing measurements to assess institutional quality (Kurtz \& Schrank, 2007). Table 2.6 gives an overview of the three indicators in percentile rank for some selected coconut exporting and importing regions in our study in 1996, 2016, and their overall average scores over 20 years. We can observe that some exporting countries, such as China, rank high on good government effectiveness and low on voice and accountability. By contrast, Brazil has improved its ranking in voice and accountability but fallen in government effectiveness and control of corruption. There are different methods to represent these six indicators. Certain bodies of literature on bilateral trade have used the six variables as separate measures (Álvarez et al., 2018; Lio \& Hu, 
2009; Martínez-Zarzoso \& Márquez-Ramos, 2018; Méon \& Weill, 2005). Other studies have constructed dummy variables based on whether the institutional measure is positive or negative (i.e. above or below the median for all countries), or by summing or averaging the scores of all six indicators into one overall measure (de Groot et al., 2005; Linders et al., 2005; de Groot et al., 2004). In order to analyze the effects of each indicator, we treat each indicator as a separate variable. For instance, if we take further scrutiny into China's scores on each of the three indicators as shown in table 6 , we can see that its percentile rank in voice and accountability rating is ranked seventh in the year 2016, where government effectiveness ranked 68.

Table 2.6: Percentile Rank of Voice and Accountability, Government Effectiveness, and Control of Corruption for selected exporting countries

\begin{tabular}{lcccc}
\hline Country & VA & GE & CC & Year \\
\hline \multicolumn{1}{c}{ Brazil } & \multicolumn{1}{c}{ Percentile Rank (1-100) } & & \\
& 58 & 51 & 57 & 1996 \\
China & 62 & 48 & 38 & 2016 \\
& 12 & 43 & 48 & 1996 \\
Indonesia & 7 & 68 & 49 & 2016 \\
& 21 & 23 & 22 & 1996 \\
Jamaica & 50 & 53 & 43 & 2016 \\
& 66 & 60 & 62 & 1996 \\
Mozambique & 70 & 69 & 52 & 2016 \\
& 41 & 50 & 41 & 1996 \\
Sri Lanka & 34 & 19 & 18 & 2016 \\
& 41 & 49 & 54 & 1996 \\
Solomon Isl. & 43 & 45 & 48 & 2016 \\
& 72 & N/A & 65 & 1996 \\
& 63 & 15 & 44 & 2016 \\
\hline
\end{tabular}

Note: Countries are listed in alphabetic order

Source: World Bank (2017)

To better interpret the results of our main variables of interest, we have rescaled the three indicators of the exporting countries to 1-100. To put things into perspective, for example, if Indonesia were to improve their score of government effectiveness from 65 points in 2016 by ten points, this increase would take them to the same level of effectiveness as China in 2016. We constructed our institutional similarities variables by using the absolute values of the difference of each indicator as follows: $\left|W G I_{i}-W G I_{j}\right|$ (Bojnec \& Ferto, 2015), where WGI refers to each of the three institutional variables, $i$ is the exporting country, and $j$ is the importing country. We obtain coconut production data from FAOSTAT. The remaining gravity model variables, which include the distance between the importing and exporting countries, gross domestic products (GDPs), indicators for common language, common religion, contiguity, and regional agreement come from the Centre d'Etudes Prospectives et d'Informations Internationales (CEPII). The EU is treated as one importing entity in this study since a large 
portion of coconuts and coconut products are exported to the Netherlands, and then re-exported to other countries within the EU 27. Hence, the Netherlands is considered the destination for measuring bilateral distances. An exporting country is said to share a common official language with the EU 27 if it shares one of its official languages with at least one country in the EU 27. Table 2.7 shows the summary statistics of our main variables of interest.

Table 2.7: Summary Statistics

\begin{tabular}{lllll}
\hline & Mean & S.d. & Min. & Max. \\
\hline Trade (1000\$) & 734.49 & 8901.70 & 0 & $611,810.6$ \\
Distance (km) & $8,641.16$ & $4,762.39$ & 505.54 & $19,146.71$ \\
GDP (US\$ millions) & $1,900,000$ & $3,600,000$ & 1,290 & $18,624,475$ \\
Production (MT) & $2,112,673$ & $4,352,028$ & 4,080 & 196,000 \\
Contiguity & .04 & .21 & 0 & 1 \\
Common off. lang. & .27 & .44 & 0 & 1 \\
Common religion & .08 & .13 & 0 & .81 \\
RTA & .14 & .35 & 0 & 1 \\
Voice \& accountability $\boldsymbol{i}$ & -.13 & .76 & -2.23 & 1.26 \\
Government Effectiveness $\boldsymbol{i}$ & -.36 & .56 & -2.27 & 1.27 \\
Control of Corruption $\boldsymbol{i}$ & -.43 & .46 & -1.67 & .66 \\
Voice \& accountability $\boldsymbol{j}$ & .19 & .98 & -1.78 & 1.67 \\
Government Effectiveness $\boldsymbol{j}$ & .81 & .93 & -1.21 & 2.44 \\
Control of Corruption $\boldsymbol{j}$ & .57 & 1.14 & -1.31 & 2.33 \\
Voice \& accountability $\boldsymbol{i} \boldsymbol{j}$ & 1.06 & 0.74 & .0000562 & 3.79 \\
Government Effectiveness $\boldsymbol{i} \boldsymbol{j}$ & 1.34 & 0.87 & .0002905 & 4.26 \\
Control of Corruption $\boldsymbol{i} \boldsymbol{j}$ & 1.30 & 0.92 & .0007986 & 3.97 \\
\hline Observations & 88935 & & & \\
\hline
\end{tabular}

\section{Empirical specification}

We use extended versions of the gravity model (Tinbergen, 1962) for our estimations. The gravity model has been used extensively in the literature to examine the different factors that influence bilateral trade. It has become increasingly popular throughout the last decade for research on trade due to its intuition, theoretical foundations, realistic equilibrium environment, flexible structure, and strong predictions (Yotov et al., 2016). Many recent studies that analyze trade and institutional quality, trade facilitation, and trade costs have utilized variations and extensions of the gravity model.

The model in its basic form takes into consideration the geographical distance between the exporting and importing countries, and the GDPs of both countries to represent the trade costs between the two (Shepherd, 2013). The intuition behind the theory is that countries with larger GDPs or countries that are closer to each other have a bigger gravity force that pulls them together (Feenstra \& Taylor, 2014), leading to larger volumes of trade. Our approach takes after Álvarez et al. (2018) with the foundations on the new trade theory, characterized by the 
Dixit-Stiglitz-Krugman assumptions by taking into account the "love for variety" preferences, increasing returns to scale technologies, and iceberg transportation costs.

In a survey of gravity models, Kabir et al. (2017) discussed the importance of modeling differentiated products. We address this by estimating the gravity model in its structural form at different levels of product aggregation: the trade effect of institutions is estimated (1) at the product-level, (2) at the aggregate coconut sector-level, and (3) at the aggregate agriculturalsector level. We compare the coconut product level with the aggregate coconut level is to see whether institutional quality affects aggregate trade in coconut products differently than it affects individual sub-categories of coconut products with different levels of value addition. Given that institutional quality indicators are not specifically designed for the coconut industry, other agricultural sectors might even benefit more than the coconut industry if institutions improve. This may even induce a shift away from coconut production and trade due to relative price changes in favor of other sectors. To consider these relative advantages in our analysis, we estimate the effect of the three institutional quality indicators on the remaining agricultural sector (defined as total agricultural exports minus exports of coconut products).

Before we derive the concrete equations for each aggregation level, we explain some gravityspecific estimation issues that need to be accounted for in order to obtain valid results. We use panel data for the estimates of our gravity model to capture the institutional changes that occur in coconut producing countries from 1996 to 2016. The data generating process of the gravity equation has a micro-theoretical foundation. Thus, we take into account multilateral trade resistance (MTR), which refers to the fact that bilateral trade flows do not only depend on trade barriers between the respective exporting and importing country but also on barriers that the exporting and importing country encounters with all of their trading partners (Adam \& Cobham, 2007).

In our structural gravity models, we address MTR with the Bonus-Vetus method, proposed by Baier and Bergstrand (2009). This approach addresses MTR by applying a first-order log-linear Taylor series approximation to the non-linear MTR terms to account for exogenous variables that influence trade costs (Shepherd, 2013).

Each trade cost variable is transformed as follows, which we illustrate for the example of the variable 'distance':

$$
\operatorname{lnDist}_{M T R i j}=\operatorname{lnDist}_{i j}-\frac{1}{N} \sum_{j=1}^{N} \ln \operatorname{Dist}_{i j}-\frac{1}{2} \frac{1}{N^{2}} \sum_{i=1}^{N_{k}} \sum_{j=1}^{N} \ln \operatorname{Dist}_{i j}
$$

, where $i=$ exporting country, $j=$ importing country, $k=$ coconut-product and $t=$ year. 
This method is preferred for this study since the three main institutional variables of interest are country-time-specific or country-pair specific (in the case of institutional similarities), respectively. Therefore, country-time and country-pair fixed effects are collinear with the institutional variables of interest which would lead to their exclusion from the model (Shepherd, 2013). The alternative approach of using the multiplicative form of exporter-time (-product) and importer-time (-product) fixed effects is also not viable due to the occurrence of many singletons during estimation. Hence, we follow Berger et al., (2013) and include importer and time fixed effects to limit omitted variable biases which might result from import regimes and the increasing role of non-tariff barriers that are specific to the importing country and traded product. Product fixed effects are also applied, but only in the aggregate coconut and agricultural sector estimations.

Since many coconut producing countries are small economies and have limited trading partners, zero trade values are frequent in our datasets, especially for the rarer coconut products. Traditional gravity estimations convert the dependent variables as logarithms, which omits zero trade data to include only positive trade flows (Martin \& Pham, 2015). In our sample, we have a total of seven coconut traded products, resulting in large portions of zeroes. This poses a problem when measuring bilateral trade as it could lead to selection bias. Different methods have been proposed to deal with zero trade. We adopt the Poisson pseudo-maximum likelihood (PPML) estimation method proposed by Santos Silva and Tenreyro (2006). It includes zero trade flows without any data transformation and provides unbiased estimates in the presence of heteroscedasticity.

We take our transformed right-hand-side variables from equation (1) and estimate their trade effects with the PPML method, first, with aggregated indicator scores. This gives us the following gravity equation per coconut product category:

$$
\begin{aligned}
X_{i, j, t}^{k}=\exp [ & \beta_{0} \\
& +\beta_{1} \text { lnDIST }_{i j}+\beta_{2} \text { lnProduction }_{i t}+\beta_{3} \text { lnGDP }_{j t}+\beta_{4} \text { LANG }_{i j}+\beta_{5} R T A_{i j t} \\
& +\beta_{6} \text { Religion }_{i j}+\beta_{7} \text { Contig }_{i j}+\beta_{8} \text { INST }_{i t}+\beta_{9} V A_{i j t}+\beta_{10} G E_{i j t}+\beta_{11} C C_{i j t} \\
& \left.+\mu_{j}+\delta_{t}\right] \in_{i j t}
\end{aligned}
$$

, where $k=$ product which means that we estimate each trade effect separately for each of the mentioned coconut products.

We then estimated the three indicators based on whether the exporting and importing countries score positive or negative on average: 


$$
\begin{aligned}
X_{i, j, t}^{k}=\exp [ & \beta_{0}+\beta_{1} \text { lnDIST }_{i j}+\beta_{2} \text { lnProduction }_{i t}+\beta_{3} \operatorname{lnGDP}_{j t}+\beta_{4} L A N G_{i j}+\beta_{5} R T A_{i j t} \\
& +\beta_{6} \text { Religion }_{i j}+\beta_{7} \text { Contig }_{i j}+\beta_{8} V A_{i t}+\beta_{9} G E_{i t}+\beta_{10} C_{i t}+\beta_{17} V A_{i j t} \\
& \left.+\beta_{18} G_{i j t}+\beta_{19} C C_{i j t}+\mu_{j}+\delta_{t}\right] \in_{i j t}
\end{aligned}
$$

For the aggregate coconut sector, we estimate the following gravity equation:

$$
\begin{aligned}
X_{i, j, k, t}=\exp [ & \beta_{0}+\beta_{1} \text { lnDIST }_{i j}+\beta_{2} \text { lnProduction }_{i t}+\beta_{3} \text { lnGDP }_{j t}+\beta_{4} \text { LANG }_{i j}+\beta_{5} R T A_{i j t} \\
& +\beta_{6} \text { Religion }_{i j}+\beta_{7} \text { Contig }_{i j}+\beta_{8} V A_{i t}+\beta_{9} G E_{i t}+\beta_{10} C C_{i t}+\beta_{17} V A_{i j t} \\
& \left.+\beta_{18} G_{i j t}+\beta_{19} C C_{i j t}+\mu_{j}+v_{k}+\delta_{t}\right] \in_{i j t}
\end{aligned}
$$

, where $\mathrm{k}=$ coconut product, but all products are estimated within one equation, thus we only obtain one coefficient estimate for the entire industry and control for product fixed effects.

For the remaining agricultural sector, we estimate the following gravity equation:

\begin{tabular}{|c|c|}
\hline Variables & Definitions \\
\hline$X_{i, j, t}^{k}$ & Bilateral trade of product $k$ between countries $i$ and $j$ \\
\hline $\boldsymbol{\beta}_{0}$ & Unknown intercept \\
\hline $\operatorname{lnDIST_{ij}}$ & Log of distance between the capital city of countries $i$ and $j$ \\
\hline lnProduction $_{i t}$ & Log of coconut production in metric tons of country $i$ \\
\hline $\ln G D P_{j t}$ & Log of GDP of country $j$ \\
\hline$L A N G_{i j}$ & $\begin{array}{l}\text { Dummy variable to indicate whether countries } i \text { and } j \text { share a common } \\
\text { official language }\end{array}$ \\
\hline$R T A_{i j t}$ & $\begin{array}{l}\text { Dummy variable to indicate whether countries } i \text { and } j \text { is part of a regional } \\
\text { trade agreement }\end{array}$ \\
\hline Religion $_{i j}$ & Dummy variable to indicate whether country $i$ and $j$ share a common religion \\
\hline Contig $_{i j}$ & Whether countries $i$ and $j$ share a border \\
\hline INST $_{i}$ & Average of the WB's six world governance indicators \\
\hline$V A_{i}$ & Voice and accountability indicator in country $i$ \\
\hline$G E_{i}$ & Government effectiveness indicator in country $i$ \\
\hline$C C_{i}$ & Control of corruption indicator in country $i$ \\
\hline$V A_{i j}$ & Voice and accountability similarity between countries $i$ and $j$ \\
\hline$G E_{i j}$ & Government effectiveness similarity between countries $i$ and $j$ \\
\hline$C C_{i j}$ & Control of corruption similarity between countries $i$ and $j$ \\
\hline
\end{tabular}

$$
\begin{aligned}
X_{i, j, t}=\exp [ & \beta_{0}+\beta_{1} \text { lnDIST }_{i j}+\beta_{2} \text { lnProduction }_{i t}+\beta_{3} \text { lnGDP }_{j t}+\beta_{4} L A N G_{i j}+\beta_{5} \text { RTA }_{i j t} \\
& +\beta_{6} \text { Religion }_{i j}+\beta_{7} \text { Contig }_{i j}+\beta_{8} V A_{i t}+\beta_{9} G E_{i t}+\beta_{10} C C_{i t}+\beta_{17} V A_{i j t} \\
& \left.+\beta_{18} G_{i j t}+\beta_{19} C C_{i j t}+\mu_{j}+\delta_{t}\right]
\end{aligned}
$$

Here, no product dimensions are included.

Table 2.8 describes each of the variables and their definition as specified in our models.

Table2. 8: List of variables in the gravity model and their definitions 


\begin{tabular}{cl}
\hline $\boldsymbol{\mu}_{\boldsymbol{j}}$ & Importer fixed effects \\
$\boldsymbol{v}_{\boldsymbol{k}}$ & Product fixed effects \\
$\boldsymbol{\delta}_{\boldsymbol{t}}$ & Time fixed effects \\
$\epsilon_{\boldsymbol{i j t}}$ & Error term, unobserved factors that change over time \\
\hline
\end{tabular}

\subsection{Results}

Table 2.9 presents the results of our PPML Bonus-Vetus estimations with aggregate indicators. Columns (1) - (7) specify the results of each of the coconut product categories. These are then compared to results to all the aggregate coconut products in column (8). Column (9) shows results from all other agricultural products (excluding coconut products) in the same 26 coconut exporting countries. Figures in brackets below the coefficients represent standard errors.

When considering aggregate measures of the six indicators, bilateral trade increases only for oilcake, where a one-point increase in the average institutional indicators leads to an $8.7 \%$ but decreases in fresh or dried coconuts by nearly seven percent. Trade in all other agricultural sectors rises by almost five percent. Similarities in voice and accountability increase trade of copra, but decreases exports of milk/water, activated carbon, and in the remaining agricultural sector. The opposite result hold for similarities in government effectiveness as trade increases in all three categories of high-value-added products and the rest of agricultural products. The result is less clear cut when two countries share similar levels of control of corruption. It appears to increase trade of coir but decreases trade of oilcake and the rest of the agricultural sector.

Table 2.10 shows results with the three separate indicators from exporters with positive average indicators. These results are compared to table 2.11 with exporters with average institutional scores that are less than zero to disentangle the effects of each indicator in different institutional settings. From here on, the two categories are referred to as positive exporters and negative exporters. The indicator, voice and accountability, shows similar trade effects across almost all categories of coconut products in both positive and negative exporters but differs in effect sizes. In positive exporting countries, a one-point increase in voice and accountability decrease trade in all products except for copra and activated carbon with the largest effect size in oilcake at $43.5 \%$ and $14.5 \%$ in coconut oil. In negative exporting countries, the results show no effect on coconut oil and copra but decrease all other coconut categories from five to around ten percent. We observe a difference between the effect of government effectiveness on low-value and highvalue products in both categories of exporters. Trade is decreased in copra and oilcake but increases in all categories that we consider as high-value plus coconut oil. Yet, in negative exporting countries, the effect on coconut oil is neutral along with copra and coir while trade 
Table 2.9: Institutional quality and exports with average institutional indicator scores

\begin{tabular}{|c|c|c|c|c|c|c|c|c|c|}
\hline Dependent Variables & Copra & Coir & $\begin{array}{l}\text { Coconut } \\
\text { Oil }\end{array}$ & Oilcake & Milk/Water & $\begin{array}{l}\text { Activated } \\
\text { Carbon }\end{array}$ & Fresh or Dried & Aggregate & $\begin{array}{l}\text { (9) } \\
\text { Remaining agricultural } \\
\text { sector } \\
\text { (excl. coconuts) }\end{array}$ \\
\hline InDistance & $\begin{array}{l}-0.426 \\
(0.704)\end{array}$ & $\begin{array}{l}0.663 \\
(0.425)\end{array}$ & $\begin{array}{l}1.090 * * * \\
(0.365)\end{array}$ & $\begin{array}{l}-2.266^{* * *} \\
(0.619)\end{array}$ & $\begin{array}{l}-0.738^{* *} \\
(0.289)\end{array}$ & $\begin{array}{l}-1.057 * * * \\
(0.255)\end{array}$ & $\begin{array}{l}0.071 \\
(0.376)\end{array}$ & $\begin{array}{l}-0.170 \\
(0.363)\end{array}$ & $\begin{array}{l}-0.599 * * * \\
(0.140)\end{array}$ \\
\hline $\operatorname{lnGDP}$ & $\begin{array}{l}6.330 * * * \\
(1.110)\end{array}$ & $\begin{array}{l}2.095 * * * \\
(0.622)\end{array}$ & $\begin{array}{l}0.230 \\
(0.159)\end{array}$ & $\begin{array}{l}1.268 * * * \\
(0.408)\end{array}$ & $\begin{array}{l}1.358 * * * \\
(0.319)\end{array}$ & $\begin{array}{l}0.395^{*} \\
(0.211)\end{array}$ & $\begin{array}{l}1.374 * * * \\
(0.271)\end{array}$ & $\begin{array}{l}0.569 * * * \\
(0.176)\end{array}$ & $\begin{array}{l}0.784 * * * \\
(0.104)\end{array}$ \\
\hline lnProduction & $\begin{array}{l}0.573 * * * \\
(0.120)\end{array}$ & $\begin{array}{l}0.626 * * * \\
(0.114)\end{array}$ & $\begin{array}{l}1.270 * * * \\
(0.127)\end{array}$ & $\begin{array}{l}2.270 * * * \\
(0.367)\end{array}$ & $\begin{array}{l}0.339 * * * \\
(0.099)\end{array}$ & $\begin{array}{l}0.740 * * * \\
(0.123)\end{array}$ & $\begin{array}{l}0.802 * * * \\
(0.111)\end{array}$ & $\begin{array}{l}0.785^{* * * *} \\
(0.082)\end{array}$ & $\begin{array}{l}0.627 * * * \\
(0.042)\end{array}$ \\
\hline Contiguity & $\begin{array}{l}1.398 \\
(1.013)\end{array}$ & $\begin{array}{l}2.084^{*} \\
(1.169)\end{array}$ & $\begin{array}{l}0.560 \\
(0.770)\end{array}$ & $\begin{array}{l}-1.307 \\
(1.091)\end{array}$ & $\begin{array}{l}1.707 * * * \\
(0.529)\end{array}$ & $\begin{array}{l}-1.309 \\
(0.993)\end{array}$ & $\begin{array}{l}0.820 \\
(0.765)\end{array}$ & $\begin{array}{l}1.067 \\
(0.755)\end{array}$ & $\begin{array}{l}0.498 \\
(0.339)\end{array}$ \\
\hline Language & $\begin{array}{l}0.624 \\
(0.697)\end{array}$ & $\begin{array}{l}-0.570 \\
(1.027)\end{array}$ & $\begin{array}{l}-0.083 \\
(0.642)\end{array}$ & $\begin{array}{l}-1.003 \\
(0.905)\end{array}$ & $\begin{array}{l}0.739 * * \\
(0.350)\end{array}$ & $\begin{array}{l}-0.274 \\
(0.664)\end{array}$ & $\begin{array}{l}-0.530 \\
(0.731)\end{array}$ & $\begin{array}{l}0.425 \\
(0.406)\end{array}$ & $\begin{array}{l}0.515^{* * *} \\
(0.234)\end{array}$ \\
\hline RTA & $\begin{array}{l}0.394 \\
(0.985)\end{array}$ & $\begin{array}{l}2.307 * * \\
(1.057)\end{array}$ & $\begin{array}{l}0.280 \\
(0.319)\end{array}$ & $\begin{array}{l}0.630 \\
(0.522)\end{array}$ & $\begin{array}{l}-0.647 \\
(0.394)\end{array}$ & $\begin{array}{l}-0.587 \\
(0.371)\end{array}$ & $\begin{array}{l}0.156 \\
(0.438)\end{array}$ & $\begin{array}{l}-0.320 \\
(0.494)\end{array}$ & $\begin{array}{l}0.334 \\
(0.221)\end{array}$ \\
\hline Religion & $\begin{array}{l}0.371 \\
(1.287)\end{array}$ & $\begin{array}{l}-9.023 * * * \\
(3.088)\end{array}$ & $\begin{array}{l}5.511 * * * \\
(2.129)\end{array}$ & $\begin{array}{l}4.207 \\
(3.562)\end{array}$ & $\begin{array}{l}-0.470 \\
(1.640)\end{array}$ & $\begin{array}{l}0.873 \\
(2.321)\end{array}$ & $\begin{array}{l}4.219 * * \\
(1.870)\end{array}$ & $\begin{array}{l}3.450 * * * \\
(1.181)\end{array}$ & $\begin{array}{l}-0.781 \\
(1.203)\end{array}$ \\
\hline Average indicator $i$ & $\begin{array}{l}-0.038 \\
(0.030)\end{array}$ & $\begin{array}{l}-0.033 \\
(0.046)\end{array}$ & $\begin{array}{l}0.033 \\
(0.026)\end{array}$ & $\begin{array}{l}0.087^{*} \\
(0.046)\end{array}$ & $\begin{array}{l}0.004 \\
(0.021)\end{array}$ & $\begin{array}{l}-0.021 \\
(0.020)\end{array}$ & $\begin{array}{l}-0.069 * * * \\
(0.024)\end{array}$ & $\begin{array}{l}-0.009 \\
(0.018)\end{array}$ & $\begin{array}{l}0.049 * * * \\
(0.008)\end{array}$ \\
\hline Voice $\&$ accountability $i j$ & $\begin{array}{l}-2.180 * * * \\
(0.608)\end{array}$ & $\begin{array}{l}-0.365 \\
(0.468)\end{array}$ & $\begin{array}{l}0.219 \\
(0.239)\end{array}$ & $\begin{array}{l}1.101 \\
(0.674)\end{array}$ & $\begin{array}{l}1.620 * * * \\
(0.297)\end{array}$ & $\begin{array}{l}1.874 * * * \\
(0.300)\end{array}$ & $\begin{array}{l}-0.173 \\
(0.445)\end{array}$ & $\begin{array}{l}1.122 * * * \\
(0.303)\end{array}$ & $\begin{array}{l}0.462 * * * \\
(0.120)\end{array}$ \\
\hline Government effectiveness $i j$ & $\begin{array}{l}1.400 * * \\
(0.613)\end{array}$ & $\begin{array}{l}0.932 \\
(0.578)\end{array}$ & $\begin{array}{l}-0.319 \\
(0.638)\end{array}$ & $\begin{array}{l}1.383 \\
(0.954)\end{array}$ & $\begin{array}{l}-1.708^{* * * *} \\
(0.471)\end{array}$ & $\begin{array}{l}-1.729 * * * \\
(0.417)\end{array}$ & $\begin{array}{l}-1.443 * * * \\
(0.405)\end{array}$ & $\begin{array}{l}-1.465^{* * * *} \\
(0.329)\end{array}$ & $\begin{array}{l}-0.447^{*} \\
(0.238)\end{array}$ \\
\hline Control of corruption $i j$ & $\begin{array}{l}0.751 \\
(0.821) \\
\end{array}$ & $\begin{array}{l}-2.999 * * * \\
(1.149)\end{array}$ & $\begin{array}{l}0.784 \\
(0.589) \\
\end{array}$ & $\begin{array}{l}2.003 * * \\
(1.005) \\
\end{array}$ & $\begin{array}{l}0.354 \\
(0.320)\end{array}$ & $\begin{array}{l}-0.475 \\
(0.417)\end{array}$ & $\begin{array}{l}-0.516 \\
(0.686)\end{array}$ & $\begin{array}{l}0.244 \\
(0.330) \\
\end{array}$ & $\begin{array}{l}0.557 * * \\
(0.276) \\
\end{array}$ \\
\hline $\begin{array}{l}\text { Importer FE } \\
\text { Time FE } \\
\text { Product FE }\end{array}$ & $\begin{array}{l}\text { YES } \\
\text { YES } \\
\text { NO }\end{array}$ & $\begin{array}{l}\text { YES } \\
\text { YES } \\
\text { NO }\end{array}$ & $\begin{array}{l}\text { YES } \\
\text { YES } \\
\text { NO }\end{array}$ & $\begin{array}{l}\text { YES } \\
\text { YES } \\
\text { NO }\end{array}$ & $\begin{array}{l}\text { YES } \\
\text { YES } \\
\text { NO }\end{array}$ & $\begin{array}{l}\text { YES } \\
\text { YES } \\
\text { NO }\end{array}$ & $\begin{array}{l}\text { YES } \\
\text { YES } \\
\text { NO }\end{array}$ & $\begin{array}{l}\text { YES } \\
\text { YES } \\
\text { YES }\end{array}$ & $\begin{array}{l}\text { YES } \\
\text { YES } \\
\text { NO }\end{array}$ \\
\hline $\begin{array}{l}\text { Observations } \\
\text { R-squared }\end{array}$ & $\begin{array}{l}8,085 \\
0.275\end{array}$ & $\begin{array}{l}12,206 \\
0.413\end{array}$ & $\begin{array}{l}16,170 \\
0.559\end{array}$ & $\begin{array}{l}8,085 \\
0.798\end{array}$ & $\begin{array}{l}16,170 \\
0.318\end{array}$ & $\begin{array}{l}8,085 \\
0.673\end{array}$ & $\begin{array}{l}16,170 \\
0.347\end{array}$ & $\begin{array}{l}88,935 \\
0.399\end{array}$ & $\begin{array}{l}7,469 \\
0.761\end{array}$ \\
\hline
\end{tabular}


Table 2.10: Institutional quality and exports: exporters with positive aggregate indicators

\begin{tabular}{|c|c|c|c|c|c|c|c|c|c|}
\hline Dependent Variables & $\begin{array}{l}(1) \\
\text { Copra }\end{array}$ & $\begin{array}{l}(2) \\
\text { Coir }\end{array}$ & $\begin{array}{l}\text { (3) } \\
\text { Coconut Oil }\end{array}$ & $\begin{array}{l}\text { (4) } \\
\text { Oilcake }\end{array}$ & $\begin{array}{l}\text { (5) } \\
\text { Milk/Water }\end{array}$ & $\begin{array}{l}\text { (6) } \\
\text { Activated Carbon }\end{array}$ & $\begin{array}{l}(7) \\
\text { Fresh or Dried }\end{array}$ & $\begin{array}{l}(8) \\
\text { Aggregate }\end{array}$ & $\begin{array}{l}\text { (9) } \\
\text { Remaining agricultural sector } \\
\text { (excl. coconuts) }\end{array}$ \\
\hline $\operatorname{lnDIST}$ & $\begin{array}{l}0.962 \\
(0.694)\end{array}$ & $\begin{array}{l}-0.348 \\
(0.351)\end{array}$ & $\begin{array}{l}1.187 * * \\
(0.477)\end{array}$ & $\begin{array}{l}-1.596^{*} \\
(0.817)\end{array}$ & $\begin{array}{l}-1.323 * * * \\
(0.330)\end{array}$ & $\begin{array}{l}-0.047 \\
(0.384)\end{array}$ & $\begin{array}{l}-0.552 * \\
(0.312)\end{array}$ & $\begin{array}{l}0.014 \\
(0.288)\end{array}$ & $\begin{array}{l}-0.592 * * * \\
(0.087)\end{array}$ \\
\hline $\operatorname{lnGDP}$ & $\begin{array}{l}8.708 * * * \\
(2.058)\end{array}$ & $\begin{array}{l}0.942 \\
(0.582)\end{array}$ & $\begin{array}{l}1.105 * * * \\
(0.318)\end{array}$ & $\begin{array}{l}2.646 \\
(1.889)\end{array}$ & $\begin{array}{l}1.415^{* *} \\
(0.577)\end{array}$ & $\begin{array}{l}1.415 * * * \\
(0.296)\end{array}$ & $\begin{array}{l}1.305 * * * \\
(0.444)\end{array}$ & $\begin{array}{l}1.201 * * * \\
(0.244)\end{array}$ & $\begin{array}{l}1.541 * * * \\
(0.118)\end{array}$ \\
\hline lnProduction & $\begin{array}{l}0.291 \\
(0.300)\end{array}$ & $\begin{array}{l}1.424 * * * \\
(0.244)\end{array}$ & $\begin{array}{l}1.239 * * * \\
(0.178)\end{array}$ & $\begin{array}{l}1.419 * * * \\
(0.314)\end{array}$ & $\begin{array}{l}0.674 * * * \\
(0.151)\end{array}$ & $\begin{array}{l}1.507 * * * \\
(0.185)\end{array}$ & $\begin{array}{l}0.677 * * * \\
(0.122)\end{array}$ & $\begin{array}{l}0.863 * * * \\
(0.097)\end{array}$ & $\begin{array}{l}0.743 * * * \\
(0.029)\end{array}$ \\
\hline Contig & $\begin{array}{l}3.661 \\
(2.230)\end{array}$ & $\begin{array}{l}1.824 * * * \\
(0.627)\end{array}$ & $\begin{array}{l}4.066 * * * \\
(1.017)\end{array}$ & $\begin{array}{l}-1.163 \\
(6.174)\end{array}$ & $\begin{array}{l}0.316 \\
(0.441)\end{array}$ & $\begin{array}{l}0.017 \\
(0.791)\end{array}$ & $\begin{array}{l}0.410 \\
(0.417)\end{array}$ & $\begin{array}{l}1.643 \\
(1.065)\end{array}$ & $\begin{array}{l}0.897 * * * \\
(0.145)\end{array}$ \\
\hline LANG & $\begin{array}{l}-0.630 \\
(1.215)\end{array}$ & $\begin{array}{l}-0.104 \\
(0.796)\end{array}$ & $\begin{array}{l}-0.252 \\
(0.837)\end{array}$ & $\begin{array}{l}-2.215 \\
(1.350)\end{array}$ & $\begin{array}{l}1.052 * * * \\
(0.391)\end{array}$ & $\begin{array}{l}0.477 \\
(0.839)\end{array}$ & $\begin{array}{l}0.016 \\
(0.676)\end{array}$ & $\begin{array}{l}0.228 \\
(0.572)\end{array}$ & $\begin{array}{l}0.640 * * * \\
(0.089)\end{array}$ \\
\hline RTA & $\begin{array}{l}2.327 \\
(1.545)\end{array}$ & $\begin{array}{l}1.916^{* *} \\
(0.848)\end{array}$ & $\begin{array}{l}-0.380 \\
(0.714)\end{array}$ & $\begin{array}{l}-4.122 \\
(3.444)\end{array}$ & $\begin{array}{l}-0.684 * \\
(0.349)\end{array}$ & $\begin{array}{l}0.194 \\
(0.311)\end{array}$ & $\begin{array}{l}0.440 \\
(0.456)\end{array}$ & $\begin{array}{l}-0.130 \\
(0.387)\end{array}$ & $\begin{array}{l}-0.446^{* * *} \\
(0.142)\end{array}$ \\
\hline Religion & $\begin{array}{l}-1.430 \\
(3.433)\end{array}$ & $\begin{array}{l}-9.556 * * * \\
(2.650)\end{array}$ & $\begin{array}{l}4.514 * * \\
(2.162)\end{array}$ & $\begin{array}{l}5.235 \\
(5.085)\end{array}$ & $\begin{array}{l}-3.229 \\
(2.304)\end{array}$ & $\begin{array}{l}-0.615 \\
(2.803)\end{array}$ & $\begin{array}{l}2.082 \\
(2.489)\end{array}$ & $\begin{array}{l}2.165 \\
(1.334)\end{array}$ & $\begin{array}{l}-0.688^{*} \\
(0.415)\end{array}$ \\
\hline Voice $\&$ accountability $i$ & $\begin{array}{l}-0.000 \\
(0.032)\end{array}$ & $\begin{array}{l}-0.089 * * * \\
(0.021)\end{array}$ & $\begin{array}{l}-0.145^{* * * *} \\
(0.026)\end{array}$ & $\begin{array}{l}-0.435 * * * \\
(0.148)\end{array}$ & $\begin{array}{l}-0.058 * * * \\
(0.021)\end{array}$ & $\begin{array}{l}-0.015 \\
(0.024)\end{array}$ & $\begin{array}{l}-0.044 * * * \\
(0.007)\end{array}$ & $\begin{array}{l}-0.102 * * * \\
(0.013)\end{array}$ & $\begin{array}{l}0.005 \\
(0.004)\end{array}$ \\
\hline Government effectiveness $i$ & $\begin{array}{l}-0.084 * * * \\
(0.028)\end{array}$ & $\begin{array}{l}-0.036 \\
(0.033)\end{array}$ & $\begin{array}{l}0.029 * \\
(0.017)\end{array}$ & $\begin{array}{l}-0.216^{* * * *} \\
(0.055)\end{array}$ & $\begin{array}{l}0.065 * * * \\
(0.014)\end{array}$ & $\begin{array}{l}0.188 * * * \\
(0.034)\end{array}$ & $\begin{array}{l}0.048 * * \\
(0.021)\end{array}$ & $\begin{array}{l}0.030 \\
(0.019)\end{array}$ & $\begin{array}{l}0.029 * * * \\
(0.005)\end{array}$ \\
\hline Control of corruption $i$ & $\begin{array}{l}0.065 * * * \\
(0.024)\end{array}$ & $\begin{array}{l}0.096 * * * \\
(0.037)\end{array}$ & $\begin{array}{l}-0.032 \\
(0.023)\end{array}$ & $\begin{array}{l}0.081 * * \\
(0.040)\end{array}$ & $\begin{array}{l}0.014 \\
(0.013)\end{array}$ & $\begin{array}{l}-0.017 \\
(0.016)\end{array}$ & $\begin{array}{l}-0.048 * * * \\
(0.014)\end{array}$ & $\begin{array}{l}-0.063 * * * \\
(0.018)\end{array}$ & $\begin{array}{l}0.011 * * \\
(0.006)\end{array}$ \\
\hline Voice \& accountability $i j$ & $\begin{array}{l}0.541 \\
(0.942)\end{array}$ & $\begin{array}{l}-0.684 * * \\
(0.346)\end{array}$ & $\begin{array}{l}-0.302 \\
(0.470)\end{array}$ & $\begin{array}{l}-7.734 * \\
(3.985)\end{array}$ & $\begin{array}{l}0.569 \\
(0.576)\end{array}$ & $\begin{array}{l}0.870 * * \\
(0.357)\end{array}$ & $\begin{array}{l}-0.269 \\
(0.276)\end{array}$ & $\begin{array}{l}-0.117 \\
(0.409)\end{array}$ & $\begin{array}{l}0.185 * * \\
(0.087)\end{array}$ \\
\hline Government effectivenessij & $\begin{array}{l}-0.122 \\
(0.733)\end{array}$ & $\begin{array}{l}1.230 \\
(0.879)\end{array}$ & $\begin{array}{l}0.632 * * \\
(0.319)\end{array}$ & $\begin{array}{l}-2.721 * * \\
(1.281)\end{array}$ & $\begin{array}{l}0.281 \\
(0.287)\end{array}$ & $\begin{array}{l}1.473 * * * \\
(0.283)\end{array}$ & $\begin{array}{l}0.145 \\
(0.437)\end{array}$ & $\begin{array}{l}0.019 \\
(0.287)\end{array}$ & $\begin{array}{l}-0.278^{* * * *} \\
(0.077)\end{array}$ \\
\hline Control of corruption $i j$ & $\begin{array}{l}2.258 * * * \\
(0.752)\end{array}$ & $\begin{array}{l}-1.311 \\
(0.896) \\
\end{array}$ & $\begin{array}{l}-0.333 \\
(0.457) \\
\end{array}$ & $\begin{array}{l}3.451 * * \\
(1.704)\end{array}$ & $\begin{array}{l}0.291 \\
(0.273) \\
\end{array}$ & $\begin{array}{l}0.192 \\
(0.293) \\
\end{array}$ & $\begin{array}{l}-1.967 * * * \\
(0.463)\end{array}$ & $\begin{array}{l}-0.076 \\
(0.365) \\
\end{array}$ & $\begin{array}{l}0.683 * * * \\
(0.166) \\
\end{array}$ \\
\hline Importer FE & YES & YES & YES & YES & YES & YES & YES & YES & YES \\
\hline Time FE & YES & YES & YES & YES & YES & YES & YES & YES & YES \\
\hline Product FE & NO & NO & NO & NO & NO & NO & NO & YES & NO \\
\hline Observations & 1,298 & 7,186 & 3,742 & 1,350 & 10,092 & 1,871 & 10,092 & 22,077 & 2,592 \\
\hline R-squared & 0.352 & 0.630 & 0.577 & 0.894 & 0.532 & 0.877 & 0.355 & 0.360 & 0.931 \\
\hline
\end{tabular}

Clustered standard errors by country pair in parentheses $* * * \mathrm{p}<0.01, * * \mathrm{p}<0.05, * \mathrm{p}<0.1$; Dependent variables are trade values in 1000 USD; Voice \& accountabilityij, government effectivenessij, and

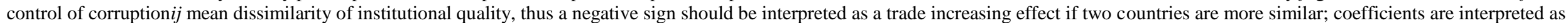
elasticities; production refers to coconut production in the coconut sectors, and total agricultural production (minus coconut production) in the remaining agricultural sector. 
Table 2.11: Institutional quality and exports: exporters with negative aggregate indicators

\begin{tabular}{|c|c|c|c|c|c|c|c|c|c|}
\hline Dependent Variables & $\begin{array}{l}\text { (1) } \\
\text { Copra }\end{array}$ & $\begin{array}{l}(2) \\
\text { Coir }\end{array}$ & $\begin{array}{l}(3) \\
\text { Coconut Oil }\end{array}$ & Oilcake & $\begin{array}{l}\text { (5) } \\
\text { Milk/Water }\end{array}$ & $\begin{array}{l}\text { (6) } \\
\text { Activated Carbon }\end{array}$ & $\begin{array}{l}\text { (7) } \\
\text { Fresh or Dried }\end{array}$ & $\begin{array}{l}\text { (8) } \\
\text { Aggregate }\end{array}$ & $\begin{array}{l}\text { (9) } \\
\text { Remaining agricultural sector } \\
\text { (excl. coconuts) }\end{array}$ \\
\hline $\operatorname{lnDIST}$ & $\begin{array}{l}-0.568 \\
(0.764)\end{array}$ & $\begin{array}{l}-0.074 \\
(0.349)\end{array}$ & $\begin{array}{l}0.650 \\
(0.479)\end{array}$ & $\begin{array}{l}-2.797 * * * \\
(0.631)\end{array}$ & $\begin{array}{l}-0.852 * * * \\
(0.317)\end{array}$ & $\begin{array}{l}-1.144 * * * \\
(0.231)\end{array}$ & $\begin{array}{l}-0.443 \\
(0.307)\end{array}$ & $\begin{array}{l}-0.466 \\
(0.322)\end{array}$ & $\begin{array}{l}-0.630 * * * \\
(0.042)\end{array}$ \\
\hline $\operatorname{lnGDP}$ & $\begin{array}{l}6.257 * * * \\
(1.054)\end{array}$ & $\begin{array}{l}2.107 * * * \\
(0.659)\end{array}$ & $\begin{array}{l}0.303 \\
(0.213)\end{array}$ & $\begin{array}{l}1.740 * * * \\
(0.377)\end{array}$ & $\begin{array}{l}1.792 * * * \\
(0.372)\end{array}$ & $\begin{array}{l}1.206 * * * \\
(0.211)\end{array}$ & $\begin{array}{l}1.143 * * * \\
(0.310)\end{array}$ & $\begin{array}{l}0.669 * * * \\
(0.171)\end{array}$ & $\begin{array}{l}0.711 * * * \\
(0.065)\end{array}$ \\
\hline $\ln$ Production & $\begin{array}{l}0.675^{* * *} \\
(0.150)\end{array}$ & $\begin{array}{l}1.552 * * * \\
(0.221)\end{array}$ & $\begin{array}{l}1.793 * * * \\
(0.248)\end{array}$ & $\begin{array}{l}2.552 * * * \\
(0.405)\end{array}$ & $\begin{array}{l}0.468 * * * \\
(0.144)\end{array}$ & $\begin{array}{l}0.976 * * * \\
(0.104)\end{array}$ & $\begin{array}{l}1.141 * * * \\
(0.145)\end{array}$ & $\begin{array}{l}1.039 * * * \\
(0.117)\end{array}$ & $\begin{array}{l}0.524 * * * \\
(0.027)\end{array}$ \\
\hline Contig & $\begin{array}{l}1.128 \\
(0.940)\end{array}$ & $\begin{array}{l}1.043^{*} \\
(0.630)\end{array}$ & $\begin{array}{l}0.092 \\
(0.634)\end{array}$ & $\begin{array}{l}-0.623 \\
(1.114)\end{array}$ & $\begin{array}{l}1.185^{* *} \\
(0.505)\end{array}$ & $\begin{array}{l}-1.411^{*} \\
(0.834)\end{array}$ & $\begin{array}{l}0.299 \\
(0.463)\end{array}$ & $\begin{array}{l}0.647 \\
(0.645)\end{array}$ & $\begin{array}{l}0.456 * * * \\
(0.104)\end{array}$ \\
\hline LANG & $\begin{array}{l}0.703 \\
(0.767)\end{array}$ & $\begin{array}{l}-0.717 \\
(0.741)\end{array}$ & $\begin{array}{l}0.011 \\
(0.748)\end{array}$ & $\begin{array}{l}-0.636 \\
(0.972)\end{array}$ & $\begin{array}{l}0.711 * * \\
(0.361)\end{array}$ & $\begin{array}{l}-0.160 \\
(0.632)\end{array}$ & $\begin{array}{l}-0.398 \\
(0.769)\end{array}$ & $\begin{array}{l}0.243 \\
(0.458)\end{array}$ & $\begin{array}{l}0.365^{* * * *} \\
(0.096)\end{array}$ \\
\hline RTA & $\begin{array}{l}0.439 \\
(0.828)\end{array}$ & $\begin{array}{l}2.742 * * * \\
(0.796)\end{array}$ & $\begin{array}{l}0.564 * * \\
(0.229)\end{array}$ & $\begin{array}{l}0.650 \\
(0.626)\end{array}$ & $\begin{array}{l}-0.463 \\
(0.371)\end{array}$ & $\begin{array}{c}-0.548^{*} \\
(0.311)\end{array}$ & $\begin{array}{l}0.048 \\
(0.430)\end{array}$ & $\begin{array}{l}-0.285 \\
(0.419)\end{array}$ & $\begin{array}{l}0.324 * * * \\
(0.078)\end{array}$ \\
\hline Religion & $\begin{array}{l}0.574 \\
(1.471)\end{array}$ & $\begin{array}{l}-7.392 * * * \\
(2.349)\end{array}$ & $\begin{array}{l}6.585 * * * \\
(2.095)\end{array}$ & $\begin{array}{l}5.510 \\
(3.446)\end{array}$ & $\begin{array}{l}-1.545 \\
(1.834)\end{array}$ & $\begin{array}{l}-0.206 \\
(2.317)\end{array}$ & $\begin{array}{l}4.775 * * * \\
(1.830)\end{array}$ & $\begin{array}{l}3.960 * * * \\
(1.188)\end{array}$ & $\begin{array}{l}-0.875^{* * *} \\
(0.341)\end{array}$ \\
\hline Voice $\&$ accountability $i$ & $\begin{array}{l}-0.015 \\
(0.033)\end{array}$ & $\begin{array}{l}-0.099 * * * \\
(0.016)\end{array}$ & $\begin{array}{l}-0.018 \\
(0.016)\end{array}$ & $\begin{array}{l}-0.048^{* *} \\
(0.024)\end{array}$ & $\begin{array}{l}-0.062 * * * \\
(0.009)\end{array}$ & $\begin{array}{l}-0.074 * * * \\
(0.009)\end{array}$ & $\begin{array}{l}-0.057 * * * \\
(0.009)\end{array}$ & $\begin{array}{l}-0.052 * * * \\
(0.009)\end{array}$ & $\begin{array}{l}-0.002 \\
(0.003)\end{array}$ \\
\hline Government effectiveness $i$ & $\begin{array}{l}-0.050 \\
(0.036)\end{array}$ & $\begin{array}{l}-0.043 \\
(0.032)\end{array}$ & $\begin{array}{l}-0.005 \\
(0.022)\end{array}$ & $\begin{array}{l}0.091 * * \\
(0.041)\end{array}$ & $\begin{array}{l}0.072 * * * \\
(0.022)\end{array}$ & $\begin{array}{l}0.084 * * * \\
(0.019)\end{array}$ & $\begin{array}{l}0.040 * * \\
(0.019)\end{array}$ & $\begin{array}{l}0.079 * * * \\
(0.012)\end{array}$ & $\begin{array}{l}0.011 \\
(0.008)\end{array}$ \\
\hline Control of corruption $i$ & $\begin{array}{l}-0.056 \\
(0.051)\end{array}$ & $\begin{array}{l}0.139 * * * \\
(0.029)\end{array}$ & $\begin{array}{l}-0.036 * * \\
(0.017)\end{array}$ & $\begin{array}{l}-0.029 \\
(0.024)\end{array}$ & $\begin{array}{l}-0.016 \\
(0.018)\end{array}$ & $\begin{array}{l}0.053 * * * \\
(0.013)\end{array}$ & $\begin{array}{l}-0.011 \\
(0.017)\end{array}$ & $\begin{array}{l}-0.017 \\
(0.012)\end{array}$ & $\begin{array}{l}0.034 * * * \\
(0.007)\end{array}$ \\
\hline Voice $\&$ accountability $i j$ & $\begin{array}{l}-2.771 * * * \\
(1.008)\end{array}$ & $\begin{array}{l}-0.890 * * * \\
(0.288)\end{array}$ & $\begin{array}{l}0.083 \\
(0.235)\end{array}$ & $\begin{array}{l}-0.471 \\
(0.300)\end{array}$ & $\begin{array}{l}0.080 \\
(0.208)\end{array}$ & $\begin{array}{l}0.225 \\
(0.266)\end{array}$ & $\begin{array}{l}-0.437 * \\
(0.257)\end{array}$ & $\begin{array}{l}0.270 \\
(0.254)\end{array}$ & $\begin{array}{l}0.247 * * * \\
(0.079)\end{array}$ \\
\hline Government effectiveness $i j$ & $\begin{array}{l}0.279 \\
(0.769)\end{array}$ & $\begin{array}{l}1.031 \\
(0.748)\end{array}$ & $\begin{array}{l}0.353 \\
(0.408)\end{array}$ & $\begin{array}{l}3.592 * * * \\
(1.321)\end{array}$ & $\begin{array}{l}-0.155 \\
(0.502)\end{array}$ & $\begin{array}{l}-0.047 \\
(0.430)\end{array}$ & $\begin{array}{l}0.227 \\
(0.359)\end{array}$ & $\begin{array}{l}0.391 \\
(0.338)\end{array}$ & $\begin{array}{l}-0.658 * * * \\
(0.140)\end{array}$ \\
\hline Control of corruption $i j$ & $\begin{array}{l}0.061 \\
(1.965)\end{array}$ & $\begin{array}{l}-0.536 \\
(0.634)\end{array}$ & $\begin{array}{l}-1.172 * * * \\
(0.413)\end{array}$ & $\begin{array}{l}-0.227 \\
(1.180)\end{array}$ & $\begin{array}{l}-0.313 \\
(0.373)\end{array}$ & $\begin{array}{l}0.356 \\
(0.336) \\
\end{array}$ & $\begin{array}{l}-0.781 * * \\
(0.395)\end{array}$ & $\begin{array}{l}-0.829 * * * \\
(0.314)\end{array}$ & $\begin{array}{l}0.923 * * * \\
(0.218)\end{array}$ \\
\hline Importer FE & YES & YES & YES & YES & YES & YES & YES & YES & YES \\
\hline Time FE & YES & YES & YES & YES & YES & YES & YES & YES & YES \\
\hline Product FE & $\mathrm{NO}$ & NO & NO & $\mathrm{NO}$ & NO & $\mathrm{NO}$ & NO & YES & NO \\
\hline Observations & 6,078 & 10,681 & 12,156 & 6,078 & 14,163 & 6,078 & 14,163 & 66,858 & 4,875 \\
\hline R-squared & 0.439 & 0.600 & 0.582 & 0.832 & 0.308 & 0.712 & 0.376 & 0.427 & 0.726 \\
\hline
\end{tabular}


increases in the high-value categories and on an aggregate level. An increase in control of corruption shows contrasting results by product and exporter category. Trade of lower-value coconut products is increased whereas trade of fresh or dried coconuts and on an aggregate level is decreased in positive exporting countries. In negative exporting countries, results don't vary by product categories. Export of coir and activated carbon is increased, while that of coconut oil is decreased. Trade is increased in the remaining agricultural sector in both exporter categories.

For positive exporters, similarities in voice and accountability increase exports of coir and oilcake while decreasing trade flows of activated carbon. In negative exporting countries, trade is increased in copra, coir, and fresh or dried. Two countries that are more similar in government effectiveness trade more only in oilcake and export less of coconut oil and activated carbon in positive exporting countries. Exports in all other agricultural products are increased in both exporter categories. Lastly, similarities in the control of corruption reduce trade in the low-value products of copra and oilcake and increase exports of fresh or dried coconuts in positive exporting countries. It also increases bilateral trade in the remaining agricultural products. Two countries similar in levels of control of corruption in negative exporting countries increase trade of coconut oil and fresh or dried categories, but trade decreases in the remaining agricultural sector.

Tables 2.12 and 2.13 show results from importers with positive aggregate indicators and those with negative indicators, respectively. We refer to them as positive and negative importers hereafter. The results closely resemble each other in the voice and accountability indicator. Exports decrease by around five percent across coconut products while no effect is observed in the remaining agricultural products in positive importing countries. For negative importers, trade is decreased with more variations in effect size in all coconut products except for copra and oilcake. Government effectiveness increases trade for positive importers in all categories of coconut products where a one-point increase leads to a seven to eight percent increase in exports. In contrast, the same indicator for negative importers, trade is either decreased or has no effect on low-value products and increases exports in high-value products. No effect is observed in the trade of remaining agricultural products. Control of corruption appears to have no influence on the export of coconut products in positive importing countries. A one-point increase in this indicator increases trade by $4.4 \%$ in all other agricultural products. Results are more varied with negative importers, where exports of coir and oilcake are increased while fresh or dried coconuts are reduced. 
Results differ more between the two categories of importers when assessing institutional similarities. They do not appear to matter much with positive importers. There is no effect in any of the product categories when two countries are more similar in voice and accountability. Trade is decreased when two countries share similarities in government effectiveness in the products of oil, oilcake, milk/water, plus on an aggregate coconut product level, however with a p-value of 0.1. Similarities in control of corruption increase trade in coconut oil and in all remaining agricultural sector.

In the negative importer category, similarities in voice and accountability stimulate trade of copra, coir, and oilcake, but exports of activated carbon decrease. Two countries more alike in government effectiveness reduce bilateral trade for coconut oil, milk/water, and on an aggregate level. Exports are increased for activated carbon and in the remaining agricultural sector. The effect size is also larger in the negative importer's category. Similarities in control of corruption have a positive effect on the trade of coconut oil and in the rest of the agricultural sector in positive importing countries. In negative importing countries, trade of copra and oilcake is decreased and export of milk/water and fresh or dried coconuts are increased. 
Table 2.12: Institutional quality and coconut exports: importers with positive aggregate indicators

\begin{tabular}{|c|c|c|c|c|c|c|c|c|c|}
\hline Dependent variables & $\begin{array}{l}(1) \\
\text { Copra }\end{array}$ & $\begin{array}{l}(2) \\
\text { Coir }\end{array}$ & $\begin{array}{l}\text { (3) } \\
\text { Coconut Oil }\end{array}$ & $\begin{array}{l}(4) \\
\text { Oilcake }\end{array}$ & $\begin{array}{l}\text { (5) } \\
\text { Milk/Water }\end{array}$ & $\begin{array}{l}\text { (6) } \\
\text { Activated Carbon }\end{array}$ & $\begin{array}{l}\text { (7) } \\
\text { Fresh or Dried }\end{array}$ & $\begin{array}{l}(8) \\
\text { Aggregate }\end{array}$ & $\begin{array}{l}\text { (9) } \\
\text { Remaining agricultural sector } \\
\text { (excl. coconuts) }\end{array}$ \\
\hline $\operatorname{lnDIST}$ & $\begin{array}{l}-0.247 \\
(0.354)\end{array}$ & $\begin{array}{l}-0.219 \\
(0.345)\end{array}$ & $\begin{array}{l}-0.380 \\
(0.324)\end{array}$ & $\begin{array}{l}-0.231 \\
(0.346)\end{array}$ & $\begin{array}{l}-0.283 \\
(0.338)\end{array}$ & $\begin{array}{l}-0.240 \\
(0.343)\end{array}$ & $\begin{array}{l}-0.267 \\
(0.343)\end{array}$ & $\begin{array}{l}-0.216 \\
(0.347)\end{array}$ & $\begin{array}{l}-0.699 * * \\
(0.350)\end{array}$ \\
\hline $\operatorname{lnGDP}$ & $\begin{array}{l}0.958 * * * \\
(0.246)\end{array}$ & $\begin{array}{l}0.809 * * * \\
(0.256)\end{array}$ & $\begin{array}{l}0.479 * * \\
(0.195)\end{array}$ & $\begin{array}{l}0.889 * * * \\
(0.244)\end{array}$ & $\begin{array}{l}1.061 * * * \\
(0.266)\end{array}$ & $\begin{array}{l}0.925 * * * \\
(0.229)\end{array}$ & $\begin{array}{l}0.940 * * * \\
(0.218)\end{array}$ & $\begin{array}{l}0.913 * * * \\
(0.254)\end{array}$ & $\begin{array}{l}0.820 * * * \\
(0.107)\end{array}$ \\
\hline lnProduction & $\begin{array}{l}0.928 * * * \\
(0.091)\end{array}$ & $\begin{array}{l}0.928 * * * \\
(0.095)\end{array}$ & $\begin{array}{l}1.033 * * * \\
(0.108)\end{array}$ & $\begin{array}{l}0.935 * * * \\
(0.096)\end{array}$ & $\begin{array}{l}0.947 * * * \\
(0.091)\end{array}$ & $\begin{array}{l}0.938 * * * \\
(0.095)\end{array}$ & $\begin{array}{l}0.962 * * * \\
(0.096)\end{array}$ & $\begin{array}{l}0.927 * * * \\
(0.096)\end{array}$ & $\begin{array}{l}0.870 * * * \\
(0.099)\end{array}$ \\
\hline Contig & $\begin{array}{l}2.031 * * * \\
(0.668)\end{array}$ & $\begin{array}{l}1.984 * * * \\
(0.662)\end{array}$ & $\begin{array}{l}0.988 \\
(0.649)\end{array}$ & $\begin{array}{l}1.932 * * * \\
(0.662)\end{array}$ & $\begin{array}{l}1.671 * * * \\
(0.631)\end{array}$ & $\begin{array}{l}1.861 * * * \\
(0.636)\end{array}$ & $\begin{array}{l}1.664 * * * \\
(0.605)\end{array}$ & $\begin{array}{l}2.012 * * * \\
(0.670)\end{array}$ & $\begin{array}{l}-0.419 \\
(0.355)\end{array}$ \\
\hline LANG & $\begin{array}{l}0.116 \\
(0.370)\end{array}$ & $\begin{array}{l}-0.027 \\
(0.381)\end{array}$ & $\begin{array}{l}0.171 \\
(0.389)\end{array}$ & $\begin{array}{l}-0.015 \\
(0.382)\end{array}$ & $\begin{array}{l}0.151 \\
(0.373)\end{array}$ & $\begin{array}{l}-0.003 \\
(0.381)\end{array}$ & $\begin{array}{l}0.027 \\
(0.380)\end{array}$ & $\begin{array}{l}-0.030 \\
(0.383)\end{array}$ & $\begin{array}{l}1.300 * * * \\
(0.417)\end{array}$ \\
\hline RTA & $\begin{array}{l}-0.910 * * \\
(0.394)\end{array}$ & $\begin{array}{l}-0.881 * * \\
(0.390)\end{array}$ & $\begin{array}{l}-0.393 \\
(0.448)\end{array}$ & $\begin{array}{l}-0.853 * * \\
(0.390)\end{array}$ & $\begin{array}{l}-0.736^{*} \\
(0.384)\end{array}$ & $\begin{array}{l}-0.814 * * \\
(0.390)\end{array}$ & $\begin{array}{l}-0.695 * \\
(0.400)\end{array}$ & $\begin{array}{l}-0.892 * * \\
(0.392)\end{array}$ & $\begin{array}{l}0.902 * * * \\
(0.320)\end{array}$ \\
\hline Religion & $\begin{array}{l}3.774 * * * \\
(1.106)\end{array}$ & $\begin{array}{l}4.403 * * * \\
(1.292)\end{array}$ & $\begin{array}{l}4.378^{* * * *} \\
(1.325)\end{array}$ & $\begin{array}{l}4.368 * * * \\
(1.287)\end{array}$ & $\begin{array}{l}3.938 * * * \\
(1.191)\end{array}$ & $\begin{array}{l}4.377 * * * \\
(1.285)\end{array}$ & $\begin{array}{l}4.396 * * * \\
(1.305)\end{array}$ & $\begin{array}{l}4.394 * * * \\
(1.291)\end{array}$ & $\begin{array}{l}-3.028 * \\
(1.699)\end{array}$ \\
\hline Voice $\&$ accountability $i$ & $\begin{array}{l}-0.052 * * * \\
(0.009)\end{array}$ & $\begin{array}{l}-0.053 * * * \\
(0.009)\end{array}$ & $\begin{array}{l}-0.045^{* * * *} \\
(0.010)\end{array}$ & $\begin{array}{l}-0.050 * * * \\
(0.009)\end{array}$ & $\begin{array}{l}-0.055^{* * * *} \\
(0.008)\end{array}$ & $\begin{array}{l}-0.050 * * * \\
(0.008)\end{array}$ & $\begin{array}{l}-0.055^{* * * *} \\
(0.009)\end{array}$ & $\begin{array}{l}-0.052 * * * \\
(0.010)\end{array}$ & $\begin{array}{l}-0.001 \\
(0.004)\end{array}$ \\
\hline Government effectiveness $i$ & $\begin{array}{l}0.069 * * * \\
(0.014)\end{array}$ & $\begin{array}{l}0.075 * * * \\
(0.016)\end{array}$ & $\begin{array}{l}0.082 * * * \\
(0.014)\end{array}$ & $\begin{array}{l}0.076 * * * \\
(0.016)\end{array}$ & $\begin{array}{l}0.079 * * * \\
(0.013)\end{array}$ & $\begin{array}{l}0.070 * * * \\
(0.014)\end{array}$ & $\begin{array}{l}0.071 * * * \\
(0.013)\end{array}$ & $\begin{array}{l}0.076 * * * \\
(0.016)\end{array}$ & $\begin{array}{l}-0.015 \\
(0.010)\end{array}$ \\
\hline Control of corruption $i$ & $\begin{array}{l}-0.007 \\
(0.014)\end{array}$ & $\begin{array}{l}-0.007 \\
(0.014)\end{array}$ & $\begin{array}{l}-0.017 \\
(0.012)\end{array}$ & $\begin{array}{l}-0.008 \\
(0.014)\end{array}$ & $\begin{array}{l}-0.012 \\
(0.012)\end{array}$ & $\begin{array}{l}-0.007 \\
(0.013)\end{array}$ & $\begin{array}{l}-0.011 \\
(0.014)\end{array}$ & $\begin{array}{l}-0.007 \\
(0.014)\end{array}$ & $\begin{array}{l}0.044 * * * \\
(0.012)\end{array}$ \\
\hline Voice \& accountability $i j$ & $\begin{array}{l}0.075 \\
(0.317)\end{array}$ & $\begin{array}{l}0.051 \\
(0.293)\end{array}$ & $\begin{array}{l}0.446 \\
(0.285)\end{array}$ & $\begin{array}{l}0.141 \\
(0.288)\end{array}$ & $\begin{array}{l}0.043 \\
(0.260)\end{array}$ & $\begin{array}{l}0.147 \\
(0.266)\end{array}$ & $\begin{array}{l}0.037 \\
(0.246)\end{array}$ & $\begin{array}{l}0.077 \\
(0.328)\end{array}$ & $\begin{array}{l}-0.039 \\
(0.185)\end{array}$ \\
\hline Government effectiveness $i j$ & $\begin{array}{l}0.510 \\
(0.374)\end{array}$ & $\begin{array}{l}0.637 \\
(0.390)\end{array}$ & $\begin{array}{l}0.605^{*} \\
(0.365)\end{array}$ & $\begin{array}{l}0.639 * \\
(0.387)\end{array}$ & $\begin{array}{l}0.628 * \\
(0.327)\end{array}$ & $\begin{array}{l}0.470 \\
(0.347)\end{array}$ & $\begin{array}{l}0.460 \\
(0.332)\end{array}$ & $\begin{array}{l}0.677 * \\
(0.396)\end{array}$ & $\begin{array}{l}0.229 \\
(0.339)\end{array}$ \\
\hline Control of corruption $i j$ & $\begin{array}{l}-0.315 \\
(0.395)\end{array}$ & $\begin{array}{l}-0.311 \\
(0.389)\end{array}$ & $\begin{array}{l}-0.694 * * \\
(0.346)\end{array}$ & $\begin{array}{l}-0.351 \\
(0.383) \\
\end{array}$ & $\begin{array}{l}-0.432 \\
(0.339)\end{array}$ & $\begin{array}{l}-0.295 \\
(0.365) \\
\end{array}$ & $\begin{array}{l}-0.487 \\
(0.380) \\
\end{array}$ & $\begin{array}{l}-0.321 \\
(0.386) \\
\end{array}$ & $\begin{array}{l}-0.900^{*} \\
(0.472) \\
\end{array}$ \\
\hline Importer FE & YES & YES & YES & YES & YES & YES & YES & YES & YES \\
\hline Time FE & YES & YES & YES & YES & YES & YES & YES & YES & YES \\
\hline Product FE & NO & NO & NO & NO & NO & NO & NO & YES & NO \\
\hline Observations & 9,722 & 10,186 & 5,093 & 13,228 & 5,093 & 13,228 & 56,023 & 9,722 & 2,502 \\
\hline R-squared & 0.681 & 0.573 & 0.863 & 0.352 & 0.664 & 0.394 & 0.442 & 0.681 & 0.832 \\
\hline
\end{tabular}


Table 2.13: Institutional quality and coconut exports: importers with negative aggregate indicators

\begin{tabular}{|c|c|c|c|c|c|c|c|c|c|}
\hline Dependent variables & $\begin{array}{l}\text { (1) } \\
\text { Copra }\end{array}$ & $\begin{array}{l}\text { (2) } \\
\text { Coir }\end{array}$ & $\begin{array}{l}(3) \\
\text { Coconut } \\
\text { Oil } \\
\end{array}$ & $\begin{array}{l}(4) \\
\text { Oilcake }\end{array}$ & $\begin{array}{l}\text { (5) } \\
\text { Milk/Water }\end{array}$ & $\begin{array}{l}\text { (6) } \\
\text { Activated Carbon }\end{array}$ & $\begin{array}{l}\text { (7) } \\
\text { Fresh or Dried }\end{array}$ & $\begin{array}{l}\text { (8) } \\
\text { Aggregate }\end{array}$ & $\begin{array}{l}\text { (9) } \\
\text { Remaining agricultural sector }\end{array}$ \\
\hline $\operatorname{lnDIST}$ & $\begin{array}{l}-9.110 * * * \\
(1.943)\end{array}$ & $\begin{array}{l}-0.354 \\
(0.332)\end{array}$ & $\begin{array}{l}1.167 \\
(0.875)\end{array}$ & $\begin{array}{l}-16.582 * * \\
(8.272)\end{array}$ & $\begin{array}{l}-1.267 * * * \\
(0.328)\end{array}$ & $\begin{array}{l}-0.550 \\
(0.561)\end{array}$ & $\begin{array}{l}-0.730 * * \\
(0.330)\end{array}$ & $\begin{array}{l}-1.131 \\
(0.702)\end{array}$ & $\begin{array}{l}-0.448 * * * \\
(0.150)\end{array}$ \\
\hline $\operatorname{lnGDP}$ & $\begin{array}{l}-9.640 * * * \\
(2.335)\end{array}$ & $\begin{array}{l}1.911 * * * \\
(0.683)\end{array}$ & $\begin{array}{l}0.182 \\
(0.202)\end{array}$ & $\begin{array}{l}-1.564 \\
(2.325)\end{array}$ & $\begin{array}{l}1.702 * * \\
(0.681)\end{array}$ & $\begin{array}{l}1.323 * * * \\
(0.251)\end{array}$ & $\begin{array}{l}1.231 * * * \\
(0.426)\end{array}$ & $\begin{array}{l}0.638 \\
(0.458)\end{array}$ & $\begin{array}{l}1.086 * * * \\
(0.113)\end{array}$ \\
\hline lnProduction & $\begin{array}{l}0.808 * * \\
(0.350)\end{array}$ & $\begin{array}{l}1.345^{* * *} \\
(0.248)\end{array}$ & $\begin{array}{l}2.178 * * * \\
(0.373)\end{array}$ & $\begin{array}{l}4.913 * * * \\
(1.173)\end{array}$ & $\begin{array}{l}0.634 * * * \\
(0.148)\end{array}$ & $\begin{array}{l}0.836 * * * \\
(0.105)\end{array}$ & $\begin{array}{l}0.710 * * * \\
(0.137)\end{array}$ & $\begin{array}{l}1.113 * * * \\
(0.150)\end{array}$ & $\begin{array}{l}0.584 * * * \\
(0.047)\end{array}$ \\
\hline Contig & $\begin{array}{l}-0.538 \\
(4.053)\end{array}$ & $\begin{array}{l}0.718 \\
(0.642)\end{array}$ & $\begin{array}{l}-2.209 \\
(1.488)\end{array}$ & $\begin{array}{l}-12.631^{*} \\
(7.439)\end{array}$ & $\begin{array}{l}-0.124 \\
(0.452)\end{array}$ & $\begin{array}{l}-0.156 \\
(0.492)\end{array}$ & $\begin{array}{l}0.300 \\
(0.440)\end{array}$ & $\begin{array}{l}-0.205 \\
(0.474)\end{array}$ & $\begin{array}{l}1.346^{* * * *} \\
(0.322)\end{array}$ \\
\hline LANG & $\begin{array}{l}3.009 * \\
(1.557)\end{array}$ & $\begin{array}{l}-0.344 \\
(0.776)\end{array}$ & $\begin{array}{l}-0.826 \\
(0.695)\end{array}$ & $\begin{array}{l}6.012 \\
(3.952)\end{array}$ & $\begin{array}{l}1.091 * * * \\
(0.411)\end{array}$ & $\begin{array}{l}-1.647 * * * \\
(0.557)\end{array}$ & $\begin{array}{l}0.032 \\
(0.678)\end{array}$ & $\begin{array}{l}1.471 * \\
(0.846)\end{array}$ & $\begin{array}{l}0.147 \\
(0.287)\end{array}$ \\
\hline RTA & $\begin{array}{l}1.312 \\
(1.417)\end{array}$ & $\begin{array}{l}1.790 * * \\
(0.775)\end{array}$ & $\begin{array}{l}0.333 \\
(0.787)\end{array}$ & $\begin{array}{l}2.770 * * \\
(1.394)\end{array}$ & $\begin{array}{l}-0.576^{*} \\
(0.335)\end{array}$ & $\begin{array}{l}0.939 \\
(0.782)\end{array}$ & $\begin{array}{l}0.448 \\
(0.450)\end{array}$ & $\begin{array}{l}0.521 \\
(0.638)\end{array}$ & $\begin{array}{l}-0.124 \\
(0.238)\end{array}$ \\
\hline Religion & $\begin{array}{l}-4.385^{*} \\
(2.463)\end{array}$ & $\begin{array}{l}-5.840 * * \\
(2.712)\end{array}$ & $\begin{array}{l}14.103 \text { *** } \\
(5.102)\end{array}$ & $\begin{array}{l}22.137 \\
(14.359)\end{array}$ & $\begin{array}{l}-2.965 \\
(2.258)\end{array}$ & $\begin{array}{l}5.619 * * * \\
(2.087)\end{array}$ & $\begin{array}{l}1.329 \\
(2.527)\end{array}$ & $\begin{array}{l}4.366 * * * \\
(1.336)\end{array}$ & $\begin{array}{l}1.193 \\
(1.462)\end{array}$ \\
\hline Voice $\&$ accountability $i$ & $\begin{array}{l}0.032 \\
(0.020)\end{array}$ & $\begin{array}{l}-0.086^{* * * *} \\
(0.020)\end{array}$ & $\begin{array}{l}-0.054 * * * \\
(0.020)\end{array}$ & $\begin{array}{l}-0.053 \\
(0.072)\end{array}$ & $\begin{array}{l}-0.068 * * * \\
(0.012)\end{array}$ & $\begin{array}{l}-0.078 * * * \\
(0.009)\end{array}$ & $\begin{array}{l}-0.042 * * * \\
(0.008)\end{array}$ & $\begin{array}{l}-0.040^{* * * *} \\
(0.013)\end{array}$ & $\begin{array}{l}-0.000 \\
(0.005)\end{array}$ \\
\hline Government effectiveness $i$ & $\begin{array}{l}-0.099 * * * \\
(0.030)\end{array}$ & $\begin{array}{l}-0.031 \\
(0.034)\end{array}$ & $\begin{array}{l}0.096 * * * \\
(0.030)\end{array}$ & $\begin{array}{l}-0.103 * \\
(0.053)\end{array}$ & $\begin{array}{l}0.088 * * * \\
(0.014)\end{array}$ & $\begin{array}{l}0.075 * * * \\
(0.025)\end{array}$ & $\begin{array}{l}0.039 * * \\
(0.018)\end{array}$ & $\begin{array}{l}0.060 * * * \\
(0.018)\end{array}$ & $\begin{array}{l}-0.016 \\
(0.013)\end{array}$ \\
\hline Control of corruption $i$ & $\begin{array}{l}0.002 \\
(0.018)\end{array}$ & $\begin{array}{l}0.104 * * * \\
(0.036)\end{array}$ & $\begin{array}{l}0.013 \\
(0.032)\end{array}$ & $\begin{array}{l}0.195 * * * \\
(0.057)\end{array}$ & $\begin{array}{l}-0.010 \\
(0.013)\end{array}$ & $\begin{array}{l}0.036 \\
(0.029)\end{array}$ & $\begin{array}{l}-0.031 * * \\
(0.013)\end{array}$ & $\begin{array}{l}-0.024 \\
(0.017)\end{array}$ & $\begin{array}{l}0.010 \\
(0.013)\end{array}$ \\
\hline Voice \& accountability $i j$ & $\begin{array}{l}-2.342 * * * \\
(0.751)\end{array}$ & $\begin{array}{l}-0.723 * * * \\
(0.280)\end{array}$ & $\begin{array}{l}0.170 \\
(0.558)\end{array}$ & $\begin{array}{l}-2.259^{*} \\
(1.333)\end{array}$ & $\begin{array}{l}0.201 \\
(0.279)\end{array}$ & $\begin{array}{l}0.985 * * * \\
(0.299)\end{array}$ & $\begin{array}{l}-0.173 \\
(0.268)\end{array}$ & $\begin{array}{l}0.067 \\
(0.284)\end{array}$ & $\begin{array}{l}0.220 \\
(0.198)\end{array}$ \\
\hline Government effectiveness $i j$ & $\begin{array}{l}-0.267 \\
(1.074)\end{array}$ & $\begin{array}{l}0.885 \\
(0.833)\end{array}$ & $\begin{array}{l}1.232 * \\
(0.689)\end{array}$ & $\begin{array}{l}-1.108 \\
(0.760)\end{array}$ & $\begin{array}{l}0.750 * * \\
(0.345)\end{array}$ & $\begin{array}{l}-1.007 * \\
(0.579)\end{array}$ & $\begin{array}{l}-0.127 \\
(0.440)\end{array}$ & $\begin{array}{l}0.945^{*} \\
(0.490)\end{array}$ & $\begin{array}{l}-1.172 * * \\
(0.476)\end{array}$ \\
\hline Control of corruption $i j$ & $\begin{array}{l}4.149 * * * \\
(0.760)\end{array}$ & $\begin{array}{l}-0.840 \\
(0.798)\end{array}$ & $\begin{array}{l}0.132 \\
(0.511)\end{array}$ & $\begin{array}{l}3.675 * * * \\
(1.261)\end{array}$ & $\begin{array}{l}-0.446^{*} \\
(0.258)\end{array}$ & $\begin{array}{l}-0.798 \\
(0.877) \\
\end{array}$ & $\begin{array}{l}-1.438 * * * \\
(0.370)\end{array}$ & $\begin{array}{l}-0.627 * \\
(0.368) \\
\end{array}$ & $\begin{array}{l}0.029 \\
(0.608) \\
\end{array}$ \\
\hline Importer FE & YES & YES & YES & YES & YES & YES & YES & YES & YES \\
\hline Time FE & YES & YES & YES & YES & YES & YES & YES & YES & YES \\
\hline Product FE & NO & NO & NO & NO & NO & NO & NO & YES & NO \\
\hline Observations & 2,942 & 7,995 & 5,884 & 2,942 & 11,027 & 2,942 & 11,027 & 32,362 & 4,967 \\
\hline R-squared & 0.862 & 0.513 & 0.660 & 0.965 & 0.455 & 0.592 & 0.244 & 0.248 & 0.833 \\
\hline
\end{tabular}

Clustered standard errors by country pair in parentheses $* * * \mathrm{p}<0.01, * * \mathrm{p}<0.05, * \mathrm{p}<0.1$; Dependent variables are trade values in 1000 USD; Voice \& accountability $i j$, government effectivenessij, and

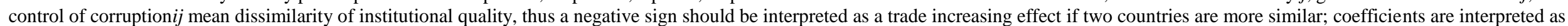
elasticities; production refers to coconut production in the coconut sectors, and total agricultural production (minus coconut production) in the remaining agricultural sector 


\subsection{Discussion}

Our first baseline results show that the overall institutional environment, as measured by an averaging the six governance indicators, does not have a concrete influence on the trade of coconut products. This finding fails to confirm H1. It, however, does better facilitate trade in all other agricultural products. By averaging the six indicators, we assume that each indicator has the same weights. Hence, each indicator in $\mathrm{H} 2, \mathrm{H} 3$, and $\mathrm{H} 4$ are tested under a given setting of whether countries have aggregate positive or negative average scores.

Our results reveal some patterns. Voice and accountability have mostly a diminishing effect on trade flows and government effectiveness increases trade aside from low-value-added products. The results for control of corruption are less clear-cut. Consistent with our hypothesis, not every indicator has the same effect on each of the product categories. The findings are also similar to those of Meon and Sekkat (2008), who suggest that the different features of institutions yield dissimilar influences on trade.

$\mathrm{H} 2$ of this study states that voice and accountability decrease the trade of coconut products. Our results confirm this hypothesis for almost all of the products assessed in both categories of exporters and importers. This is consistent with the findings of Berden et al., (2014) who find that higher levels of voice and accountability negatively affect trade flows and levels of foreign direct investment (FDI) and Martinez-Zarzoso and Ramos (2018), whose findings show lower levels of exports in the Middle East and North African countries. In positive exporters, the effect size is quite noteworthy for coconut oil at $14.5 \%$ as coconut oil is the most traded coconut product globally. Yet, in negative exporting countries, there is no effect. We conclude that more voice and rights to laborers and farmers disrupt the processing and export of coconut products in producing countries that have a better overall institutional setting. Low-value-added products are just as affected perhaps due to the labor-intensive procedures involved, for example, the drying of copra and the weaving of coir products. We observe that this indicator has no effect on the trade of all other agricultural products across the board. H3 asserts that government effectiveness increases bilateral trade of, especially high-value products. This is confirmed by our results across all high-value product categories. We infer from this result that further processing of coconuts is facilitated by the provision of complementary services and contract enforcement. However, while we expected that government effectiveness would also increase trade in low-value products, albeit to a lesser extent than for high-value products, our results show that this is not the case. Trade of some low-value-added products is decreased in the positive exporter and negative importer 
category. It's possible that countries have better average scores export more high-value products at the expense of those with lesser value. More than half of the negative importing countries are also coconut exporters. It's probable that countries like the Philippines and Indonesia need their copra to extract oil and have no need to export them to countries in this category.

H4 states that better control of corruption increases trade of all coconut categories. Here, the results are less obvious. Notably, in importing countries with positive scores, it has no effect on any of the product categories, yet, trade of the remaining agricultural sector benefits. The literature is also mixed in this regard. While some of the estimated coefficients are statistically significant, there is no clear pattern in its effects according to product categories among the exporter categories. Our results confirm that the effects of corruption in coconut trade are complex and we cannot conclude whether it fits the "grease the wheel" or "sand the wheel" argument discussed by Ben Ali and Mdhillat (2015).

H5 states that institutional similarities would increase trade flows. This is not supported by our results. First, similarities in government effectiveness show mostly decreasing effects for coconut products, yet, it increases the trade of all other agricultural products in the same countries, except in positive importing countries. This suggests that similarities in this indicator, in fact, redirect trade away from coconut products towards all other categories of agricultural commodities. A second reason could be that most of the coconut producing countries score generally lower in government effectiveness than the most important importing countries. This, together with the producing countries' natural endowments of coconut trees may serve as an explanation of the negative trade effect of similarities. With this argument, we shadow Meon and Sekkat (2008) who suggest that when nations have natural endowments of a commodity that determine their comparative advantage, in this case, coconuts, then the influence of institutions might be of subordinate importance, or in our case even negative due to limited alternatives. Another possibility could be that government effectiveness in most importing countries has improved from 1996 to 2016, whereas for some exporting countries, scores have decreased, increasing the distance of similarities in this indicator. One further explanation could be the role of informal institutions. Many of coconut producing countries are emerging markets whose exchange relationships could often rely on informal and network-based norms (Yang et al., 2018). Furthermore, social networks could weaken the effect of formal institution's legal enforceability (Yang et al., 2018).

Similarities in voice and accountability and control of corruption show mixed trade effects across different categories of exporters and importers. It differs considerably depending on the 
exporter/importer categories. Even though control of corruption does not make a pronounced effect on coconut trade itself, we do see that similarities in this indicator with negative exporter and importer categories lead to an increase in aggregate coconut products. Since this result holds for countries with negative aggregate scores, this could suggest that two countries with equally bad levels of corruption trade more with each other. As Ben Ali and Mdhillat (2015) and Horsewood and Voicu (2012) suggest, if two states think that bribery in business transactions is tolerated, then this could increase their trade transactions with each other. Our results are mostly consistent with the literature on the effect of traditional gravity variables.

\subsection{Conclusions}

Studies to date suggest that institutional quality is a determinant of bilateral trade. This is due to effects such as a reduction in transaction costs and better contract enforcement. We add to the literature by studying the effect and influence of institutions on the international trade performance of coconuts by using an extended structural gravity model. We first assess how the overall institutional environment, as measured by an average of the six World Bank's world governance indicators, influence the export performance of coconut products. Our results do not show that the overall institutional environment leads to an increase in the export of coconut products. We then measure the effects of three indicators according to categories of positive and negative exporting and importing countries

We hypothesize that an increase in government effectiveness and control of corruption indicators to increase bilateral trade flows of coconut products. At the same time, we expect better performance in voice and accountability would have negative trade effects. Lastly, we argue that trade would increase between the two countries when they share similarities in the three respective indicators. Our results support some, but not all of these hypotheses. We confirm that institutional quality matters for the trade of coconut products with variations in different institutional environments. Government effectiveness plays a bigger role in enhancing trade of high-value products, while voice and accountability decrease trade of both high-value and low-value-added coconut products. The effect size of these findings is comparable in importing countries with negative aggregate indicator scores. Contrary to the findings of Bojnec and Ferto (2009), we fail to confirm the hypothesis that two countries similar in institutions lead to an increase in bilateral trade. We should note that while some indicators show negative effects in certain categories of coconut products, the effects on the export performance in the remaining agricultural sectors are either positive or statistically insignificant. 
Existing literature on institutional quality on export performance only assessed trade in general, or in certain aggregate sectors. Product and institutional indicator-specific studies are lacking. Our study is a first attempt to close this literature gap by considering institutional and product heterogeneities. Although our results provide evidence that government effectiveness is more important than voice and accountability and control of corruption in fostering trade of highvalue coconut products, country-specific case studies for different coconut producing regions are needed that may complement our findings.

One limitation of our study is that the institutional indicators do not allow us to assess specifically to individual product categories. We have in part addressed this by showing the trade effect for the entire agricultural sector. However, in a macro-level study, we are unable to identify winners and losers individually with institutional indicators that assess the entire economy. Our study focuses exclusively on coconut exports, therefore, our findings should not be seen as transferrable to other crops and commodities. Further research is needed in other agricultural products with various levels of value addition to study the influence of institutions and governance on international market integration. This would allow for more general conclusions, while our results are sector-specific.

Our results produce a number of policy implications. Many countries in our study vary in their individual indicators. While aggregating the scores gives an impression of the institutional environment of the country, it's still difficult to assess whether a country scoring high on government effectiveness and low on control of corruption says about their overall institutional setting. We address this in our study by looking at indicators individually.

Improving government effectiveness is crucial for strengthening exports in coconuts, which is a sector of major economic relevance in many of our exporting nations. Despite findings that show a decrease in coconut trade when there is an increase in voice and accountability it also has a neutral effect on the entire agricultural sector, hinting that countries with higher levels of voice and accountability do not necessarily suffer on an aggregate level, only the coconut sector. Furthermore, it would not be unreasonable to predict that voice and accountability could have an effect similar to the Kuznet's (1955) curve. As this indicator first increases, it disrupts the coconut processing stage. However, once it reaches a certain turning point, the effect it has on coconut exports will become positive. 


\section{Appendix}

Table A2.1: Exporting and importing economies

\begin{tabular}{|c|c|}
\hline Country Groups & Members \\
\hline Exporters & $\begin{array}{l}\text { Brazil, China, Cote d'Ivoire, Dominican Republic, Fiji, Ghana, India, } \\
\text { Indonesia, Jamaica, Kiribati, Malaysia, Marshall Islands, Mexico, } \\
\text { Mozambique, Myanmar, Nigeria, Papua New Guinea, Philippines, Samo, } \\
\text { Solomon Islands, Sri Lanka, Tanzania, Thailand, Vanuatu, Venezuela, } \\
\text { Vietnam }\end{array}$ \\
\hline Importers & $\begin{array}{l}\text { Australia, Canada, China, EU27, Hong Kong, Indonesia, Japan, Korea, } \\
\text { Laos, Malaysia, Philippines, Russia, Singapore, Thailand, USA }\end{array}$ \\
\hline
\end{tabular}

Table A2.2: Correlation table of the three governance indicators in exporting countries

\begin{tabular}{llll}
\hline & VA & GE & CC \\
\hline VA & 1.0000 & & \\
GE & 0.1859 & 1.0000 & \\
CC & 0.5493 & 0.5824 & 1.0000 \\
\hline
\end{tabular}

Table A2.3: Correlation table of institutional similarities between exporting and importing regions

\begin{tabular}{llll}
\hline & VAij & GEij & CCij \\
\hline VAij & 1.0000 & & \\
GEij & 0.1723 & 1.0000 & \\
CCij & 0.2772 & 0.8243 & 1.0000 \\
\hline
\end{tabular}

Table A2.4: Harmonized System (HS) codes and Average Unit Values

\begin{tabular}{lll}
\hline HS Code & Product & Avg. Unit Value \\
\hline 1203 & Copra & .403 \\
080111 & Fresh or dried, desiccated & 1.416 \\
080119 & Fresh or dried, other than desiccated & .409 \\
151311 & Coconut oil and its fractions, crude & .833 \\
151319 & Coconut oil and its fractions, other than crude & 1.097 \\
200819 & Nut milk, including coconut & 3.062 \\
220290 & Plant-based water, including coconut & .808 \\
230650 & Oil-cake and other residues, from the extraction of copra & .145 \\
380210 & Activated carbon & 1.34 \\
530511 & Coconut coir, raw & .261 \\
530519 & Coconut coir, other & .263 \\
\hline
\end{tabular}

Source: UN Comtrade 


\section{Nut Production:}

With the exception of Cote d'Ivoire, Mozambique, Nigeria, Tanzania, and Vietnam, all other coconut producing countries listed in this study almost exclusively only produce coconuts according to nuts that are used to produce HS Code 200819.

Table A2.5: Share of coconut to total nut production in five countries

\begin{tabular}{ll}
\hline Country & Share of Coconut to Total Nut Production \\
\hline Cote d'Ivoire & $49.42 \%$ \\
Mozambique & $81.54 \%$ \\
Nigeria & $28.9 \%$ \\
Tanzania & $81.17 \%$ \\
Vietnam & $60.33 \%$ \\
\hline
\end{tabular}

Table A2.6: World governance indicator scores in exporting countries in 1996 and 2016

\begin{tabular}{|c|c|c|c|c|c|c|c|}
\hline Exporter & VA 1996 & VA 2016 & GE1996 & $\begin{array}{l}\text { GE } \\
2016\end{array}$ & $\begin{array}{l}\mathrm{CC} \\
1996\end{array}$ & $\begin{array}{l}\text { CC } \\
2016\end{array}$ & Average \\
\hline Brazil & 0.24 & 0.47 & -0.14 & -0.18 & -0.02 & -0.44 & 0.01 \\
\hline China & -1.36 & -1.62 & -0.35 & 0.36 & -0.27 & -0.25 & -0.53 \\
\hline Côte d'Ivoire & -0.58 & -0.28 & -0.26 & -0.67 & -0.26 & -0.54 & -0.98 \\
\hline Dominican Republic & 0.06 & 0.19 & -0.22 & -0.25 & -0.42 & -0.78 & -0.32 \\
\hline Fiji & 0.15 & -0.03 & -0.12 & -0.26 & 0.66 & 0.13 & -0.21 \\
\hline Ghana & -0.21 & 0.64 & -0.12 & -0.20 & -0.34 & -0.17 & -0.01 \\
\hline India & 0.48 & 0.41 & -0.11 & 0.10 & -0.38 & -0.30 & -0.25 \\
\hline Indonesia & -0.92 & 0.14 & -0.71 & 0.01 & -0.86 & -0.39 & -0.56 \\
\hline Jamaica & 0.59 & 0.69 & 0.14 & 0.41 & 0.19 & -0.16 & 0.05 \\
\hline Kiribati & 1.15 & 1.03 & & -0.45 & & 0.25 & 0.10 \\
\hline Malaysia & -0.18 & -0.47 & 0.54 & 0.88 & 0.38 & 0.11 & 0.35 \\
\hline Marshall Islands & 1.23 & 1.20 & & -1.56 & & -0.06 & -0.07 \\
\hline Mexico & -0.04 & -0.09 & 0.23 & 0.14 & -0.51 & -0.77 & -0.13 \\
\hline Mozambique & -0.28 & -0.39 & -0.14 & -0.85 & -0.42 & -0.87 & -0.39 \\
\hline Myanmar & -1.89 & -0.85 & -1.21 & -0.98 & -1.50 & -0.65 & -1.52 \\
\hline Nigeria & -1.55 & -0.30 & -0.92 & -1.09 & -1.19 & -1.04 & -1.13 \\
\hline Papua New Guinea & 0.08 & 0.19 & -0.34 & -0.73 & -0.43 & -0.92 & -0.61 \\
\hline Philippines & 0.26 & 0.14 & -0.31 & -0.01 & -0.36 & -0.53 & -0.37 \\
\hline Samoa & 0.74 & 0.76 & 0.39 & 0.54 & -0.03 & 0.28 & -0.51 \\
\hline Solomon Islands & 0.81 & 0.49 & & -0.99 & 0.34 & -0.34 & -0.48 \\
\hline Sri Lanka & -0.27 & -0.11 & -0.18 & -0.21 & -0.06 & -0.28 & -0.31 \\
\hline Tanzania & -0.64 & -0.18 & -0.69 & -0.55 & -0.70 & -0.51 & -0.43 \\
\hline Thailand & 0.31 & -1.10 & 0.18 & 0.34 & -0.36 & -0.40 & -0.12 \\
\hline Vanuatu & 0.63 & 0.69 & & -0.88 & 0.22 & -0.10 & 0.16 \\
\hline Vietnam & -1.09 & -1.41 & -0.58 & 0.01 & -0.49 & -0.40 & -1.11 \\
\hline
\end{tabular}


Table A2.7: World governance indicator scores in importing countries in 1996 and 2016

\begin{tabular}{llllllll}
\hline Importer & VA 1996 & VA 2016 & $\begin{array}{l}\text { GE } \\
\text { 1996 }\end{array}$ & GE2016 & CC 1996 & CC2016 & Average \\
\hline Australia & 1.44 & 1.30 & 1.80 & 1.58 & 1.88 & 1.77 & 1.59 \\
Canada & 1.57 & 1.38 & 1.74 & 1.80 & 2.03 & 1.98 & 1.63 \\
China & -1.36 & -1.62 & -0.35 & 0.36 & -0.27 & -0.25 & -0.52 \\
Hong Kong & 0.33 & 0.27 & 1.04 & 1.86 & 1.44 & 1.58 & 1.31 \\
Indonesia & -0.92 & 0.14 & -0.71 & 0.01 & -0.86 & -0.39 & -0.60 \\
Japan & 1.07 & 1.00 & 0.91 & 1.83 & 1.19 & 1.51 & 1.19 \\
Korea & 0.67 & 0.63 & 0.47 & 1.07 & 0.38 & 0.37 & 0.69 \\
Lao PDR & -1.13 & -1.73 & -0.64 & -0.39 & -0.72 & -0.93 & -0.92 \\
Malaysia & -0.18 & -0.47 & 0.54 & 0.88 & 0.38 & 0.11 & 0.35 \\
Philippines & 0.26 & 0.14 & -0.31 & -0.01 & -0.36 & -0.53 & -0.34 \\
Russian Federation & -0.22 & -1.21 & -0.45 & -0.22 & -1.05 & -0.86 & -0.73 \\
Singapore & 0.14 & -0.28 & 1.99 & 2.21 & 2.11 & 2.07 & 1.50 \\
Thailand & 0.31 & -1.10 & 0.18 & 0.34 & -0.36 & -0.40 & -0.07 \\
United States & 1.35 & 1.10 & 1.52 & 1.48 & 1.57 & 1.33 & 1.33 \\
EU27 & 1.13 & 1.07 & 1.13 & 1.12 & 1.04 & 1.04 & 1.08 \\
\hline
\end{tabular}




\title{
3 Fiji's participation in the global coconut value chain: Opportunities and challenges
}

\begin{abstract}
This paper explores the institutional challenges and opportunities in Fiji's integration into the global value chain. Fiji is naturally endowed with coconut palms across its many islands. However, the coconut sector remains rudimentary with little value-addition. Coconut products of high-value are now being produced and exported throughout the world. While many coconut producing countries have benefitted from this coconut demand surge, Fiji has been unable to benefit from the international market. This study utilizes a mixed-methods approach to analyze the challenges and opportunities. First, we looked on a macro-level at the link between institutional quality and Fiji's export of coconut products. Then, we look in-depth by conducting semi-structured interviews with stakeholder groups in Fiji to gain an understanding of the perceived challenges and opportunities. Our empirical results show that increased scores in the government effectiveness and voice and accountability indicators enhance coconut exports from Fiji, suggesting that domestic institutions play an important role. Interviews with key actors reveal that communications among each stakeholder group are fragmented. The main institutional actors and the producers have different perceptions of the industry's challenges, thus resulting in different ideas on how to address the issues. There is potential for Fiji to benefit from the current coconut boom. Institutional actors and producers need to gain an understanding of each other's perceptions and make an effort to work together toward a common goal.
\end{abstract}

Keywords: Coconuts, Fiji, Global Value Chains, Institutions, Qualitative Analysis

JEL codes: Q02 Q13 P48

This paper is published in the Journal of Agribusiness in Developing and Emerging Economies. This is a single-authored paper by Jessie Lin. However, it could not have been possible without the insightful feedback from various colleagues.

Acknowledgments: Thanks to Dr. Lisa Jaeckering for assisting in identifying the research questions and providing constructive feedback in the analysis of the study. I would also like to acknowledge Prof. Stephan von Cramon-Taubadel for insightful remarks on previous versions of this paper. Thanks also to Anette Ruml for her helpful comments. 


\subsection{Introduction}

In the last few decades, there have been significant changes in the agricultural and food industry in developing countries. This, together with increasing demands for exotic commodities, such as coconuts, has provided opportunities for many of these countries to participate in global agrifood chains (Trienekens and Willems 2007). Studies to date suggest that small and remote countries have much to gain by global integration, such as increases in specialization, economies of scale, and income (Breisinger et al. 2019; Kowalski et al. 2015; Streeten 1993). In addition, international trade can reap more benefits to small economies than larger ones due to economies of scale, increasing returns, and capital accumulation for its economic development (Streeten, 1993).

There has been an increase in international demand for coconut products in recent years. Coconuts are now increasingly being transformed into high-value and niche products that require more complex processing and innovations throughout the global value chain. This current trend is largely driven by non-traditional products, such as coconut milk and coconut water (Abdulsamad, 2016). Historically, the production and trade of coconuts centered on coconut oil. Today, more than 40 coconut products are being produced and traded worldwide (FAO 2013) and the number is increasing.

Fiji is naturally endowed with coconut palms. Coconuts, in the form of copra (dried coconut flesh from which oil is extracted), is one of the main agricultural products while crude coconut oil is one of the main export commodities (CIA 2019). The Fijian agricultural sector plays a large role in the country's economy as it contributes to $13.5 \%$ of the country's economy and makes up $44 \%$ of the labor force (CIA 2019). Today, coconuts are considered mostly as raw materials as there are minimal value-adding activities in Fiji. Because of this, farmers in Fiji are dependent on and vulnerable to world market prices, thus, increasing the uncertainty of their livelihood options (FAO 2013). Yet, with this current coconut product diversification boom, there is potential to generate incentives for value-adding activities (FAO 2013). The returns for farmers and firms are higher if they have market opportunities for them to shift production away from processing copra. Doing so can lead to higher profits for farmers. It is estimated in the international market that the average price paid for one coconut is around 11 US cents if sold as crude coconut oil, 33 cents as desiccated coconuts, and 55 cents as either coconut milk or coconut water (FAO 2013).

While many coconut producing countries, such as the Philippines and Sri Lanka, are benefitting from this surge in global coconut demand, other countries such as Fiji have yet to be integrated into the international market. Copra was once one of the major export commodities of Fiji, 
however, the industry has since been deteriorating due to sharp declining international price trends and damages caused by natural disasters. The lack of knowledge, assets, technologies, and market access has further hindered Fiji to participate in this current global coconut demand. Furthermore, Fiji's geographical location is prone to frequent cyclones and floods. These factors further increase farmers' risk and the need for institutional efforts to manage and facilitate the value-addition process. The Fijian government has implemented programs and policies throughout the years aimed to tackle these problems. Despite the efforts, many schemes have yet to be successful. These recurring failed efforts prove to be inefficient and crowd out spending that could be used for other agricultural activities (ADB 2013).

Institutional arrangements have the ability to better facilitate cooperation among different actors that can ease market fluctuations and reduce transaction costs (Arias et al. 2013). Institutional quality can influence whether countries only export low-value products, or whether they can integrate into more complex value chains (Dollar \& Kidder, 2017). Dollar et al. (2016) find that different measures of domestic institutional quality influence a country's participation in global value chains. Within the coconut trade, Lin et al. (2020) find that higher scores in government effectiveness lead to an increase in trade of high-value coconut products.

At the same time, past research has not looked into specific case studies to understand why or how countries integrate into the global coconut value chain.

The objective of this study is to explore the potential for Fiji to integrate into the global coconut value chain. More specifically, we look at the role of formal institutions in facilitating this process. We add to the literature by utilizing a mixed-methods approach to address our objectives. We first look at macro-level trade effects by using three indicators from the World Bank's World Governance Indicator's (WGI) index and assess their influence on Fiji's coconut exports to the top 15 coconut importing countries in the world. To further support our quantitative analysis, we then look qualitatively into a case study. We conducted semistructured interviews with actors from several stakeholder groups in Fiji to gain a better understanding of the complex issues. The goal is to understand the perceptions of key stakeholder groups in the sector. We aim to answer the following research questions:

R1. What is the role of formal institutions in facilitating Fiji's global integration?

R2: What are the challenges and opportunities perceived by each actor?

The organization of this paper is as follows. Section 2 provides an overview of the Fijian coconut industry and some of the country's existing conditions. We then review the literature 
on institutions and global value chains in section 3. Section 4 introduces our methodology and research area. We present our results in section 5 followed by a discussion. Finally, section 6 concludes.

\subsection{Background}

Coconut palms have often been referred to as the "tree of life." Not only are they a raw material source, but they also play an integral role in the traditional lifestyles in Pacific Island countries (Green 1991). For smallholders in the Pacific Island countries, coconut palms are key to income generation, nutritional consumption, and materials for construction, weaving, and vessels (Warner 2007).

Coconut production is a year-round activity. Around $90 \%$ of coconuts are cultivated on small farms, ranging between 0.5 to four hectares (Prades et al. 2016). Coconut palms start to flower between four to ten years after planting and can live to 100 years (Foale, 2003). Harvest of nuts is usually done one year after flowering (Batugal, et al., 2005). Coconuts have the potential to generate high economic returns if utilized appropriately since all parts of the coconut tree and fruit can be processed into both edible and inedible products (Balawan 2010).

The coconut industry in Fiji began in 1873 when the islands were ceded to Queen Victoria of England and became a colony under the monarchy. The following year, coconut plantations began to flourish. By 1877, copra became Fiji's major export (Silsoe 1963). During the Second World War, Australian trading companies began milling copra into oil within the country. Due to the instability of coconut oil prices, the Fijian government introduced the Copra Stabilization Scheme in 1975 to ease the global price fluctuations. The now state-owned Copra Millers was built in 1983 in an effort to support smallholder farmers to gain a stable source of income. In the mid to late 1980s, world oil prices collapsed. This so-called oil glut was caused by an oversupply of crude oil after the energy crisis that occurred in the late seventies. Since then, copra and coconut oil prices have been fluctuating, as shown in figure 3.1. In 1998, the Coconut Industry Development Authority Act was established with the intention to resuscitate the coconut sector with research and extension services (Bula n.d.). The Food and Agricultural Organization (FAO) commissioned an appraisal of the coconut industry report in Fiji in 2008, yet, little has changed since the dissemination of the report. In February of 2016, Hurricane Winston, a category five cyclone, struck Fiji, devastating much of the country's agricultural land and infrastructure. The estimated damage to the crop and livestock sector is estimated at 104 million US Dollars (Wall 2016). Many coconut plantations were severely damaged, with many still yet to fully recover after two years. 


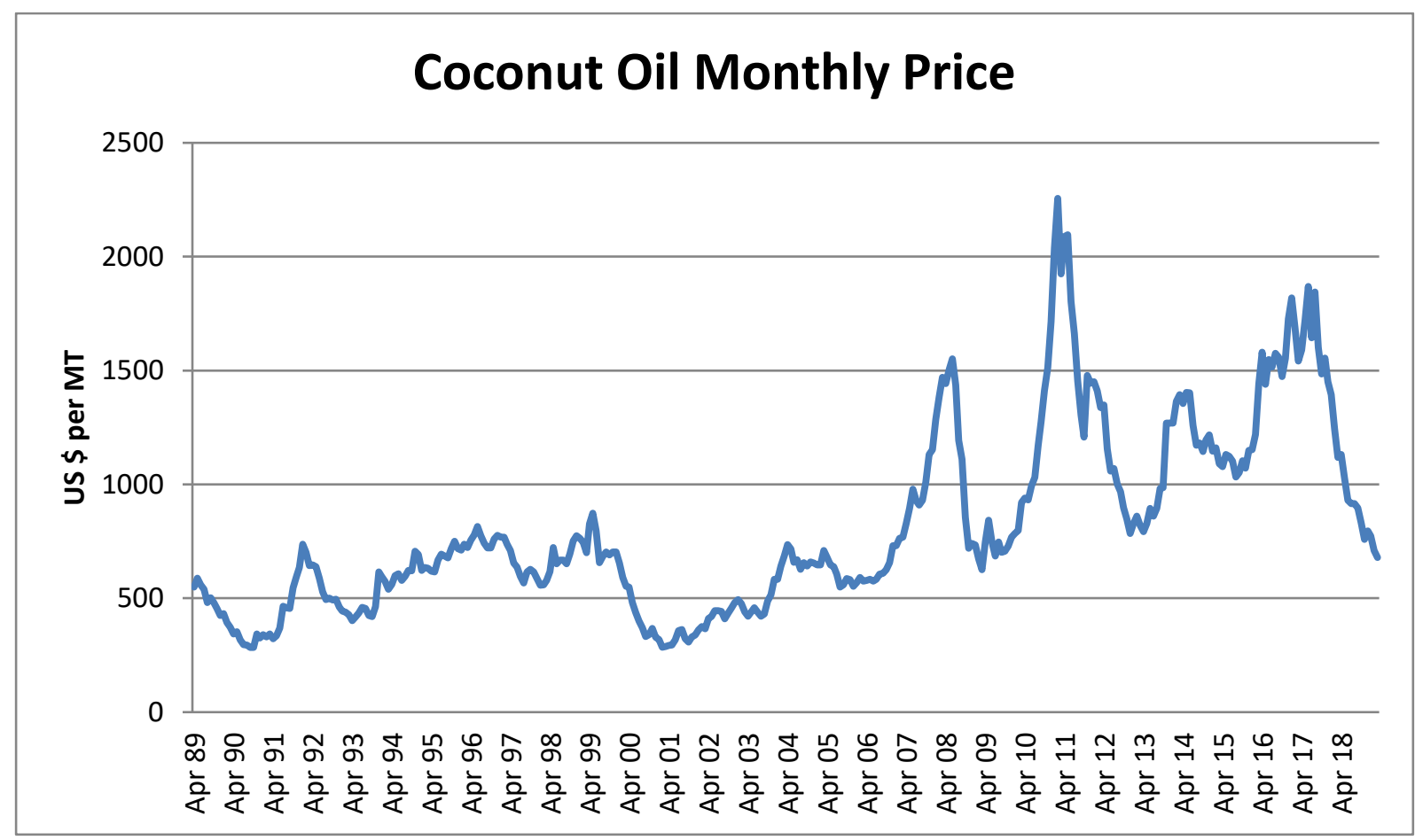

Figure 3.1: Monthly price of coconut oil since 1989; source (Indexmundi)

Coconut palms take up around $23 \%$ of arable land in Fiji (FAO, 2008). Copra production drastically decreased in the past decades from an estimated 41,000 tons in the 1950s to less than 7,000 tons in 2012 as shown in figure 3.2 (FAO 2013). Reasons for decreased production include labor scarcity and low returns from copra, natural disasters, expiring land leases, and other competing shorter-term crops such as kava and taro (FAO 2013).

Around $70 \%$ of coconut palms are estimated to be senile in Fiji (FAO 2013), meaning that they are past the years of increasing productivity level. The declining productivity of palms has proved to be a significant challenge for the country's coconut sector. The government of Fiji has implemented replanting programs in the past and present. It has set the priority for coconut production to reach the level to that of 1977 as part of the country's 2020 agriculture sector policy agenda. Yet, despite the efforts, replanting schemes have so far not been successful.

Some constraints are specific to Fiji. A report by the FAO in 2013 identified the main challenges to the Fijian coconut sector as the following: high transportation costs, labor scarcity, low returns, senile palms, higher returns from crops such as kava and taro, and natural disasters, such as cyclones. Additionally, other external factors, such as the aggressive promotion of palm oil in countries such as Indonesia have largely affected the price and competitiveness of coconut oil worldwide (Gaskell, 2015). 


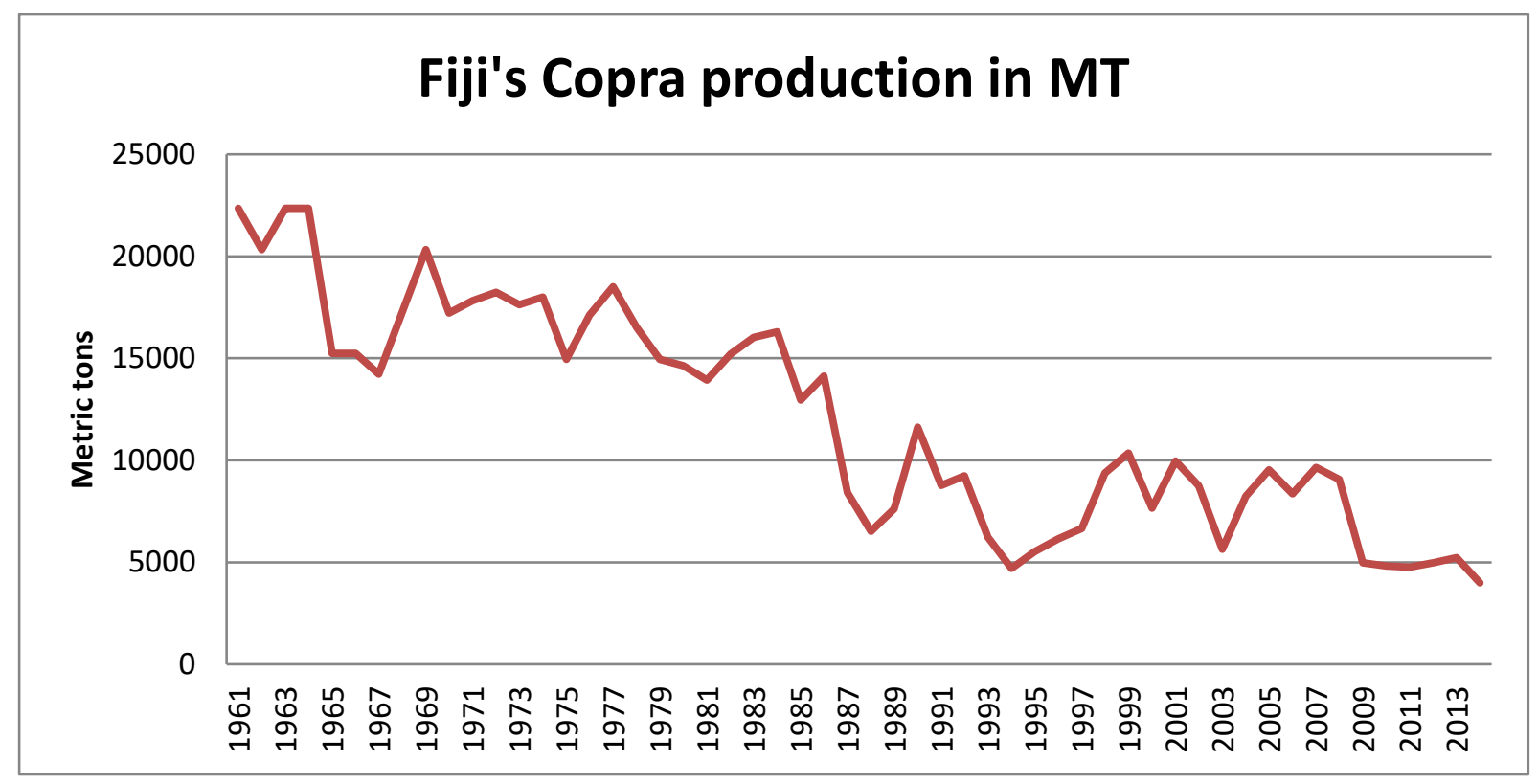

Figure 3.2: Fiji's copra production in metric tons; source: FAOSTAT

The coconut harvest method in Fiji consists of collecting nuts that have fallen to the ground. This method differs from other harvesting techniques that consist of picking nuts from the palm by climbing (Green 1991). This harvesting technique poses several disadvantages. First, the nuts can be lost, particularly in overgrowing groves that are unmanaged. Second, the delay of time in nut collection can lead to germination, reducing both the quantity and the quality of the coconuts. Lastly, inadequate storage time and copra drying methods result in inconsistent and inferior quality of copra that is prone to aflatoxin contaminations (Balawan 2010). The methods of harvesting and copra processing have been passed down for generations. Unless there are opportunities for higher earnings, there is little incentive to alter the current production techniques nor will farmers replant (Balawan 2010).

Many farmers and small producers lack the knowledge and ability to diversify their production (Selwyn, 2008). There is no current edible oil market on a commercial scale. Without the technological knowledge and machines needed for the production of higher value-added products, small countries in the Pacific can only rely on the export of crude oil to other coconut producing countries, such as the Philippines, who have machinery in place for further value addition (Young and Pelomo, 2014).

The land ownership system of the country is limiting economic development (Prasad \& Tisdell, 1996). Most coconut producing land belongs to the category of "native land", which accounts for almost $90 \%$ of land in Fiji and belongs to the native communities. The land is governed by the iTaukei Land Trust Board (TLTB). In effect, this kind of land is owned by village chiefs in communities that hold power distribution rights (Bawalan 2010). In some villages, the role of 
collecting coconuts and processing copra is decided within the clans of the communities (Bawalan 2010). Though lands can be leased through customary land rights holders to investors, it nonetheless creates the "common goods" problem. Farmers have little incentive to properly manage and clean coconut groves because they do not have ownership of the land. The lack of land ownership means farmers do not have secure collateral to access credit and loans (Duncan \& Sing, 2009). Additionally, this type of tenure system is at odds with the commercial interests of private industries, thus limiting business investments (Boydell, 2010).

While these circumstances may put Fiji at a disadvantage to integrate globally, they do not completely hinder Fiji's capacity to integrate into global value chains. According to an assessment by McGregor (2007) of capabilities to export high-value agricultural products, Fiji scores higher than other countries in the Pacific Islands in terms of market access opportunities. One reason is that Fiji already has an established and consistent freight shipments to markets in Australia, New Zealand, Japan, and the United States (McGregor, 2007). In 2016, Fiji exported almost US\$ 90 million worth of agricultural commodities and products, with taro, cassava, green ginger, eggplant, and kava as the top export commodities (Fiji Department of Agriculture). Much trade takes place through regional and multilateral agreements with Australia, New Zealand, and the European Union (Juswanto \& Ali, 2014). The South Pacific Regional Trade and Economic Co-operation Agreement (SPARTECA) between Pacific Island countries and Australia and New Zealand allow for duty-free access to certain markets. Given that Fiji already has established trade access, its remoteness should not be seen as a major impediment for the coconut sector to integrate on a global level.

\subsection{Theoretical concepts}

This section gives an overview of value chain concepts and institutions. We then link institutions and their role in a country's participation in global value chains.

Value chains are defined as "the full range of activities which are required to bring a product or service from conception, through the different phases of production, delivery to final consumers, and final disposal after use" (Kaplinsky and Morris 2001, p. 4). They are considered as networks that support physical, financial, and informational flows (Angelucci \& Conforti, 2010). These flows are seen as effective ways to support and promote smallholder farmers and their incomes via market integration and value addition (Angelucci \& Conforti, 2010). The value chain idea was conceptualized by Porter (1985) to assess firms' competitive advantage. The concept is then widely discussed to address the process of exchanges of commodities and the coordination of processing along a chain on a global scale (Gereffi 1994; 
Gereffi et al. 2005; Kaplinsky and Morris 2001; Ponte and Gibbon 2005). More recently, there have been discussions on the role of institutions in global value chain participation (Dollar et al. 2016; Dollar and Kidder 2017) and international trade (Álvarez et al. 2018; MartínezZarzoso and Márquez-Ramos 2018; Meon and Sekkat 2008). These studies suggest that better institutions lead to better international integration and increased trade.

We define institutions after North (1991, p. 97) as "the humanly devised constraints that structure political, economic and social interactions." We are interested in what the author calls the "formal rules" of institutions, which are constitutions, laws, and property rights (North 1991). Institutions have the ability to influence and facilitate each step of the value chain. As value chains become more complex and differentiated, the role of legal institutions become more crucial (Dollar \& Kidder, 2017). Countries with better institutions are able to facilitate long-term contracts and agreements at different stages along the value chain, which allows for an increase in exports of products with more complex processing (Martincus \& Gallo, 2009). As agricultural production becomes more mechanized and capital intensive, the focus within value chains has increasingly shifted from primary production to processing and value addition (Diao et al. 2014; El-Enbaby et al. 2016; Breisinger \& Diao, 2008). An upgrade in value chains can have beneficial spill-over effects on other areas of the economy (Breisinger et al. 2019). Furthermore, developing agricultural value chains can be pro-poor in the case of poorer households engaging in the value chain as a primary activity and earning higher farm revenues or the household consuming the final product at lower prices (Breisinger et al., 2019).

Mohan (2016) finds that upgrading value chains can bring profit opportunities for small firms, especially when local institutions contribute to the process. In Kenya, smallholders who participate in avocado export markets are associated with higher levels of income (Amare et al., 2019). Deans et al. (2018) find in their research on cocoa value chains in Ghana that a more integrated approach has a positive effect on the social, human, and natural capital of farmers than conventional value chain collaborations. In the Kenyan flower sector, Zylberberg (2013) illustrates that integration into the world market can reduce price fluctuations and risk for farmers. The coconut sector in Fiji can be likened to that of the cocoa industry in Africa, albeit at a much smaller scale, where the production involves mostly smallholder farmers who are in a vulnerable position in fluctuating market conditions (Barrientos \& Asenso-Okyere, 2009). In order to stay competitive in the fast-changing international market, there is a need for product innovation to create new markets and differentiate itself from traditional markets. Natural disasters, political instability, and market fluctuations further disrupt the value-chain process. As value chains become more complex and the distance between destinations lengthened, the 
vulnerabilities and risks involved increase. To mitigate these potential risks, a value chain network that facilitates information exchange between stakeholders should be created (Christopher \& Peck, 2004).

\subsection{Methodology}

We utilize a mixed-methods approach to answer our four research questions as proposed in section 1. Specifically, we address RQ1 by looking on a macro-level at the role of different domestic institutional indicators on coconut exports. Next, we use qualitative methods to answer RQ2. This is done by conducting semi-structured interviews with key stakeholder groups to grasp the various perceptions of each group.

\section{Trade Effects}

Following Lin et al. (2020), we assess the role of institutions on Fiji's coconut export performance to the top 15 coconut importing countries. To estimate the determinants of bilateral trade flows in coconut products, we gather trade data and proxies for trade costs from various sources for the years 1996-2016. We obtain bilateral coconut trade data from the United Nations Commodity Trade (UNComtrade) database, via the World Integrated Trading System. We use data on import values by the 15 largest importers of coconut products from Fiji measured in US Dollars. Import data is considered to be more dependable since governments have higher incentives to track imports for tax purposes (Francois \& Manchin, 2013).

To measure institutional quality, we utilize the World Bank's WGIs from the years 1996 to 2016. The World Bank published the indicators bi-yearly from 1996 to 2002, and annually since then. For the years 1997, 1999, and 2001, the values from the previous year are used. The WGI is one of the most recognized and referenced indicators in research. It is based on hundreds of variables created by 33 international organizations (Kaufmann et al. 2009). The six indicators are scaled from -2.5 to 2.5. Higher values correspond to better governance, where zero is the median score.

For the purpose of our study, we categorize the six indicators into three dimensions (Lin et al., 2020; Berden et al. 2014; Lio and Hu 2009; Lio and Liu 2008; Méon and Weill 2005). One indicator is selected from each of the three dimensions of indicators: voice and accountability, government effectiveness, and control of corruption. Since the indicators are themselves correlated, each indicator could affect trade directly or indirectly by its influence on the other indicators (Lio and Liu 2008). To better interpret the results of our main variables of interest, we have rescaled the three indicators of the exporting countries to 1-100. Figure 3.3 shows Fiji's institutional indicator scores from 1996 to 2017 . We observe that all three indicator scores 
decreased severely in the late 2000s. This is perhaps due to the political coup that took place in 2006. The scores have since then recovered to levels above 0 .

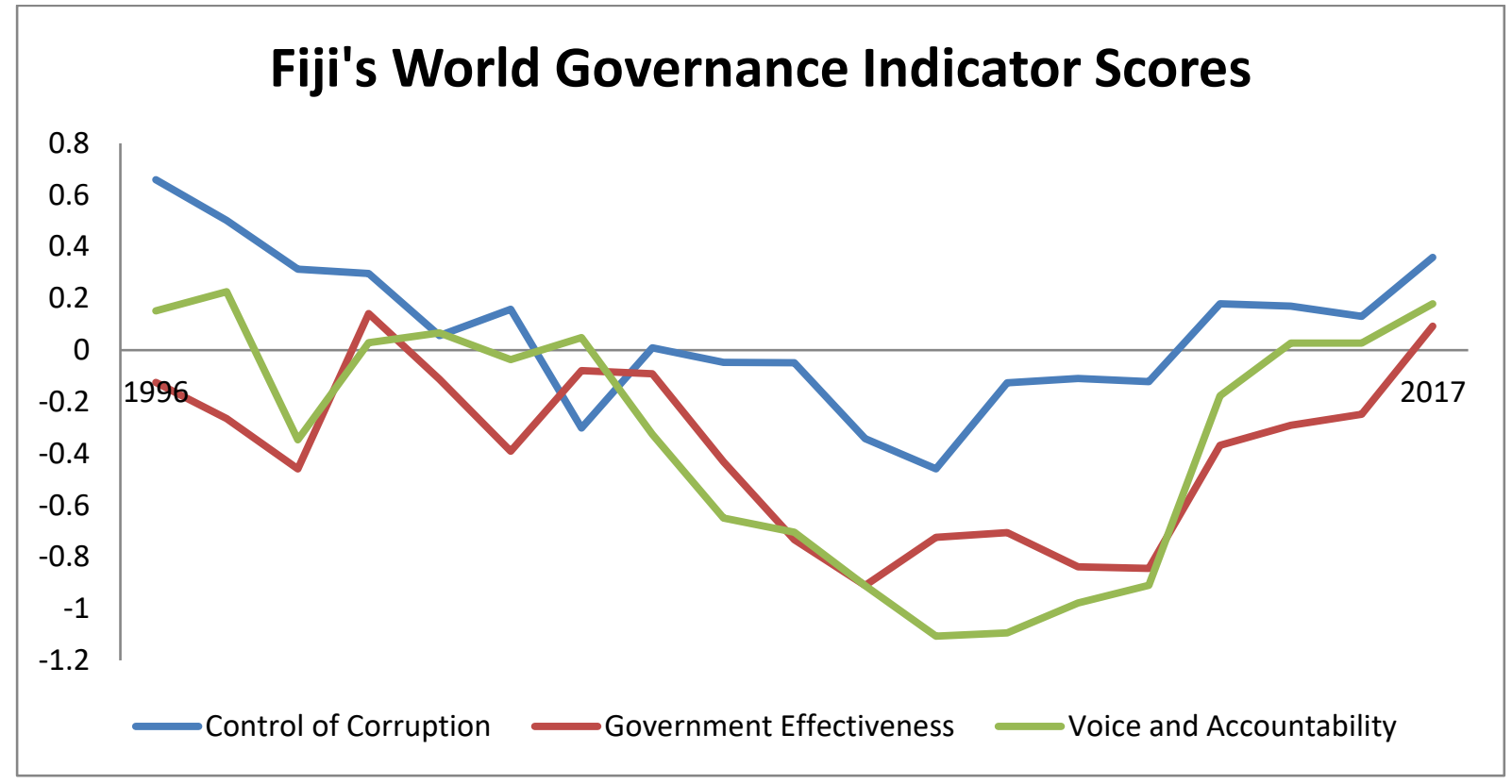

Figure 3.3: Fiji's world governance indicators score 1996-2017

We obtain gravity model variables, which include the distance between the importing and exporting countries, gross domestic products (GDPs), indicators for sharing a common language, common religion, contiguity, and regional agreement come from the Centre d'Etudes Prospectives et d'Informations Internationales. We treat the European Union (EU) as a single importing entity in this study since a significant portion of coconuts and their processed products are exported to the Netherlands, and then re-exported to other countries within the EU 27. Hence, the Netherlands is considered the destination for measuring bilateral distances. A producing country is said to share a common official language with the EU 27 if it shares one of its official languages with at least one country in the EU 27.

To estimate trade effects, we utilize the gravity model (Tinbergen 1962), which has been used extensively in trade literature, for our estimations. The model in its basic form considers the geographical distance between the exporting and importing countries and the GDPs of both countries to represent the trade costs between the two (Shepherd, 2013). The intuition behind the theory is that countries with larger GDPs or countries that are closer to each other have a larger gravity force that pulls them together (Feenstra and Taylor 2014), leading to greater volumes of trade. To address the frequent occurrence of zero trade values, we adopt the Poisson pseudo-maximum likelihood estimation method (Santos Silva \& Tenreyro, 2006).

The gravity equation is denoted as: 


$$
\begin{gathered}
X_{i, j, t}=\exp \left[\beta_{0}+\beta_{1} \operatorname{lnDIST}_{i j}+\beta_{2} \operatorname{lnGDP}_{j t}+\beta_{3} L A N G_{i j}+\beta_{4} \text { RTA }_{i j t}+\beta_{5} \text { Religion }_{i j}\right. \\
\left.+\beta_{6} \text { Contig }_{i j}+\beta_{7} V A_{i t}+\beta_{8} G E_{i t}+\beta_{9} C C_{i t}+\mu_{j}+\delta_{t}\right] \epsilon_{i j t}
\end{gathered}
$$

\section{Data collection}

The qualitative aspect of this study is based on primary data collected over a six-week period from November to December 2018 in three areas within Fiji, shown in figure 3.4. We first visited the capital city of Suva, where the Ministry of Agriculture and international organizations are based. Field visits took place on the island of Taveuni and Vanua Levu where the majority of coconut plantations and smaller coconut groves are located. The city of Savusavu, Vanua Levu is where the government-owned mill, Copra Millers, is located.

Our data collection method involved semi-structured interviews with key actors from multiple stakeholder groups in the coconut sector. To explore the perceptions of our respondents, we developed a list of pre-determined questions that allow for follow-up questions and discussions during the interviews. Respondents were also asked about their forms of communication with other groups of stakeholders in order to identify the bottlenecks within the network of groups. We selected certain stakeholder categories based on purposive sampling. Respondents were chosen based on their experience, involvement, and influence in the Fijian coconut value chain.

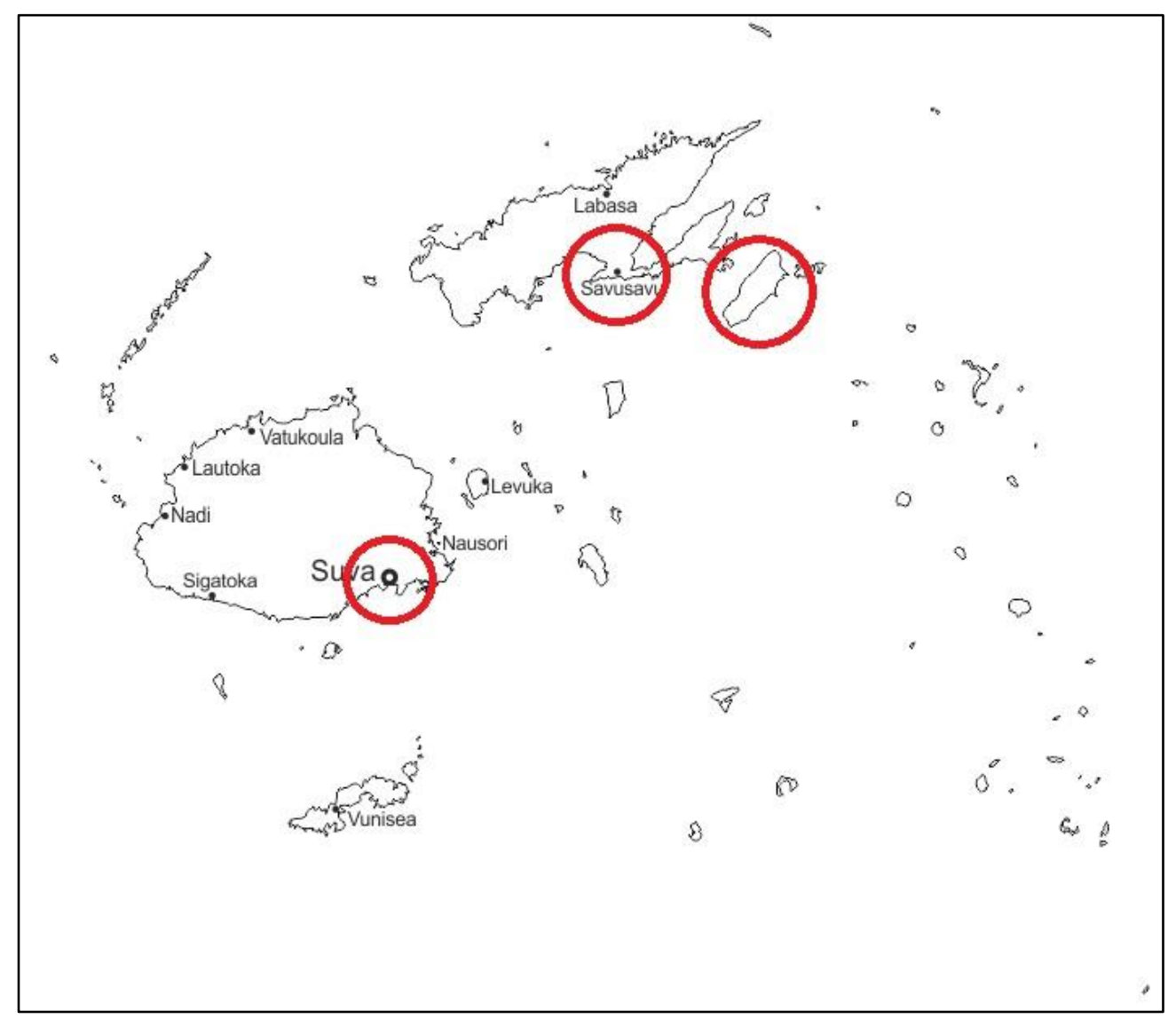

Figure 3.4: Map of research sites in Fiji 
We interviewed a total of 34 respondents from several stakeholder groups including government officials, international researchers, academic researchers, farmers/copra processors, women's group members, and private industries, as shown in Table 3.1. Of the categories, farmers and women's group members were selected using snowball sampling. Participants were referred by informants in the research division of the Ministry of Agriculture. Though the sample size does not equate a statistically designed sample, the aim is to capture multiple perceptions from each of the key stakeholder groups involved.

Each interview was transcribed and analyzed using the NVivo 12 Pro software. We identified issues and recurring themes that were mentioned and discussed by each actor. The common themes were then grouped to identify the different perceptions of the interviewees to assess specific challenges, potentials, and other unforeseen factors.

Table 3.1: Categories and number of stakeholder's interviews

\begin{tabular}{ll}
\hline Type & Number of respondents \\
\hline Government agencies (agriculture extension and & 4 \\
research) & \\
Academic & 2 \\
Private industry (factories and farm estates) & 5 \\
Copra Millers & 2 \\
Farmer/Copra processor & 12 \\
Virgin coconut oil maker (women's group member) & 6 \\
International consultants & 3 \\
\hline Total & 34 \\
\hline
\end{tabular}

With the different groups of stakeholders, a communications network diagram was created according to the interviews to outline the type of relationships that exists among the different interest groups.

\subsection{Results}

Table 3.2 presents the results of our estimations on the effects of institutional quality on Fijian coconut exports. Figures in brackets below the coefficients represent standard errors.

Our results suggest that after accounting for standard gravity model determinants of trade such as distance and GDP, an increase in the voice and accountability and government effectiveness indicators leads to an increase in trade of coconut products from Fiji to the top 15 importing countries. A one-point increase in voice and accountability leads to a $2.7 \%$ increase in trade whereas a one-point increase in government effectiveness increases trade by $9.6 \%$. Conversely, control of corruption has the opposite effect on trade, where a one-point increase leads to an almost nine percent decrease in coconut exports from Fiji. The effect sizes are notable for the indicators of government effectiveness and control of corruption. 
Table 3.2: Institutional quality and coconut exports from Fiji

\begin{tabular}{ll}
\hline Dependent Variables & Coconut Exports \\
\hline lnDist & $-0.133^{*}$ \\
& $(0.078)$ \\
lnGDP $i$ & $0.215^{* * *}$ \\
& $(0.014)$ \\
Common off. language & 0.230 \\
& $(0.157)$ \\
RTA & $-0.486^{* * *}$ \\
& $(0.183)$ \\
Common religion & $1.983^{* * *}$ \\
& $(0.501)$ \\
Voice and accountabilityi & $0.027^{* * *}$ \\
& $(0.003)$ \\
Government effectiveness $i$ & $0.096^{* * *}$ \\
& $(0.007)$ \\
Control of corruption $i$ & $-0.088^{* * *}$ \\
& $(0.006)$ \\
\hline Time FE & YES \\
Importer FE & YES \\
\hline Observations & 32,175 \\
R-squared & 0.091 \\
\hline
\end{tabular}

Standard errors in parentheses, $* * * \mathrm{p}<0.01, * * \mathrm{p}<0.05, * \mathrm{p}<0.1$

\section{Coconut value chain in Fiji}

Our interviews confirm that coconuts are collected by hand on plantations and small farms after they have fallen off the palms. Figure 3.5 shows the levels of value-addition and the actors involved in the activities from harvest to the export of crude coconut oil. The first level of mature coconut processing involves sorting, dehusking, taking out fresh kernels, and drying the kernel into copra. Unlike other major coconut producing countries, this activity is done as an additional on-farm value addition activity by farmers who also collect coconuts on communal lands. Almost every village member engages in the harvest of coconuts. The ones who do not own a copra dryer collect whole nuts and sell to those who own a dryer. By-products that emerge from this level of processing are coconut husks, which can be transformed into coir, and coconut shells, which are often made into activated carbon (charcoal) and handicrafts. These activities are mostly non-commercial.

The next steps comprise of processing copra into crude coconut oil. Farmers transport dehusked coconuts and/or copra to Copra Millers, who is the only buyer. Alternatively, twice a week, Copra Millers sends out a truck to collect both copra and nuts from larger farmers in Vanua Levu. The oil is pressed by the mill on a larger scale. Because each farmer has his own set of hand-made copra dryers and different techniques of making copra, the quality of copra is inconsistent. These copra ends up at Copra Millers for milling, resulting in crude oil, the end 
product, of varying quality. The majority of crude oil is exported to countries such as Malaysia and Singapore for further processing into cosmetics.

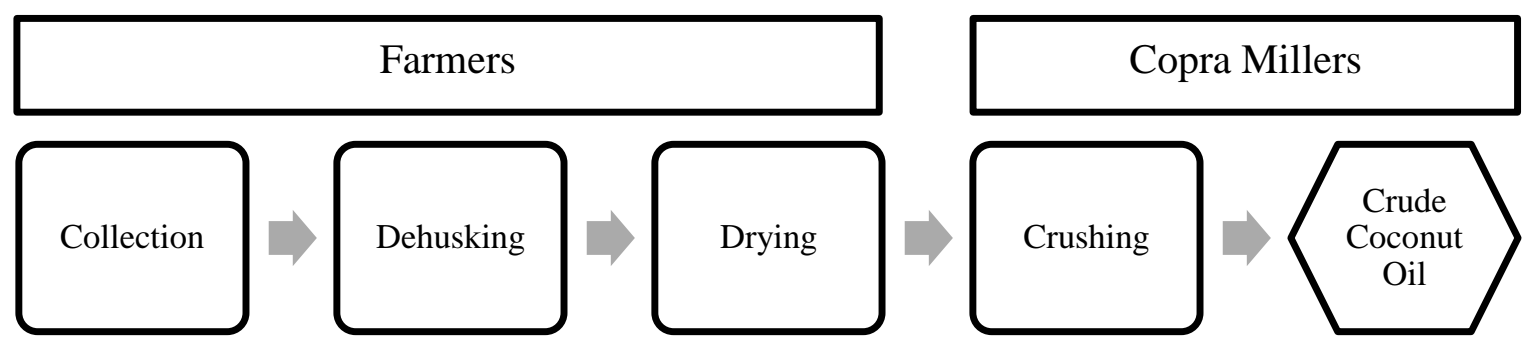

\section{Figure 3.5: Coconut value chain in Fiji}

Virgin coconut oil (VCO) production exists on a small-scale level for domestic sales. The product is mostly produced at the household level by members of local women's groups. The production is either done by hand or by using a machine provided by the government. Many interviewees identify one farm that exports VCO to the United States. However, this particular farmer refused our request for a visit, the production method is unknown.

Table 3.3: Price comparison of different coconut items

\begin{tabular}{lll}
\hline Item & Average Price & No. of coconuts \\
\hline Copra & \$1000 per ton ${ }^{1}$ & $\sim 5000$ \\
Whole coconuts & 25 cents or 40 cents each & 1 \\
Small whole coconut & 10 cents per each & 1 \\
Virgin coconut oil & $\$ 15$ per 0.5 liter & $\sim 5$ \\
\hline
\end{tabular}

1 One metric ton of copra produces around 610 kilograms of oil (World Bank, 1986).

Table 3.3 shows a price comparison of the different value-added coconut items farmers and producers obtain. Copra receives the lowest returns and is also the most labor-intensive. Selling whole coconuts would be more cost-effective for farmers, as there is no further processing involved. The limiting factor is transporting the nuts as they are both heavy and bulky. The trucks sent out by Copra Millers only go to larger plantations, thus, excluding smaller farmers.

\section{Communication network diagram}

We present the communication network diagram that outlines the stakeholder groups involved in the coconut sector and the different types of interactions and communication flows that take place, as adapted after Oancea et al. (2017). This diagram, shown in figure 3.6, is created based on the responses from our interviews. There are three types of communication flows represented: information, human resources, and physical flows. Information flow refers to the sharing of knowledge; human resources means skills and training provisions; and physical flows denote to the materials being exchanged, in our case, the sale of coconuts. Within the 
Ministry of Agriculture, there is an extension division and a research division. The extension division goes to farmers and women's groups to collect information on how much copra and VCO are produced. The relationship is one-sided as farmers comment that extension officers don't provide any information to them. Extension workers mostly collect information from farmers, but rarely offer advice or assistance. "They come and sit for five minutes and tell me stories about what they think, then you don't hear from them for about another six months" (Farmer, Savusavu).

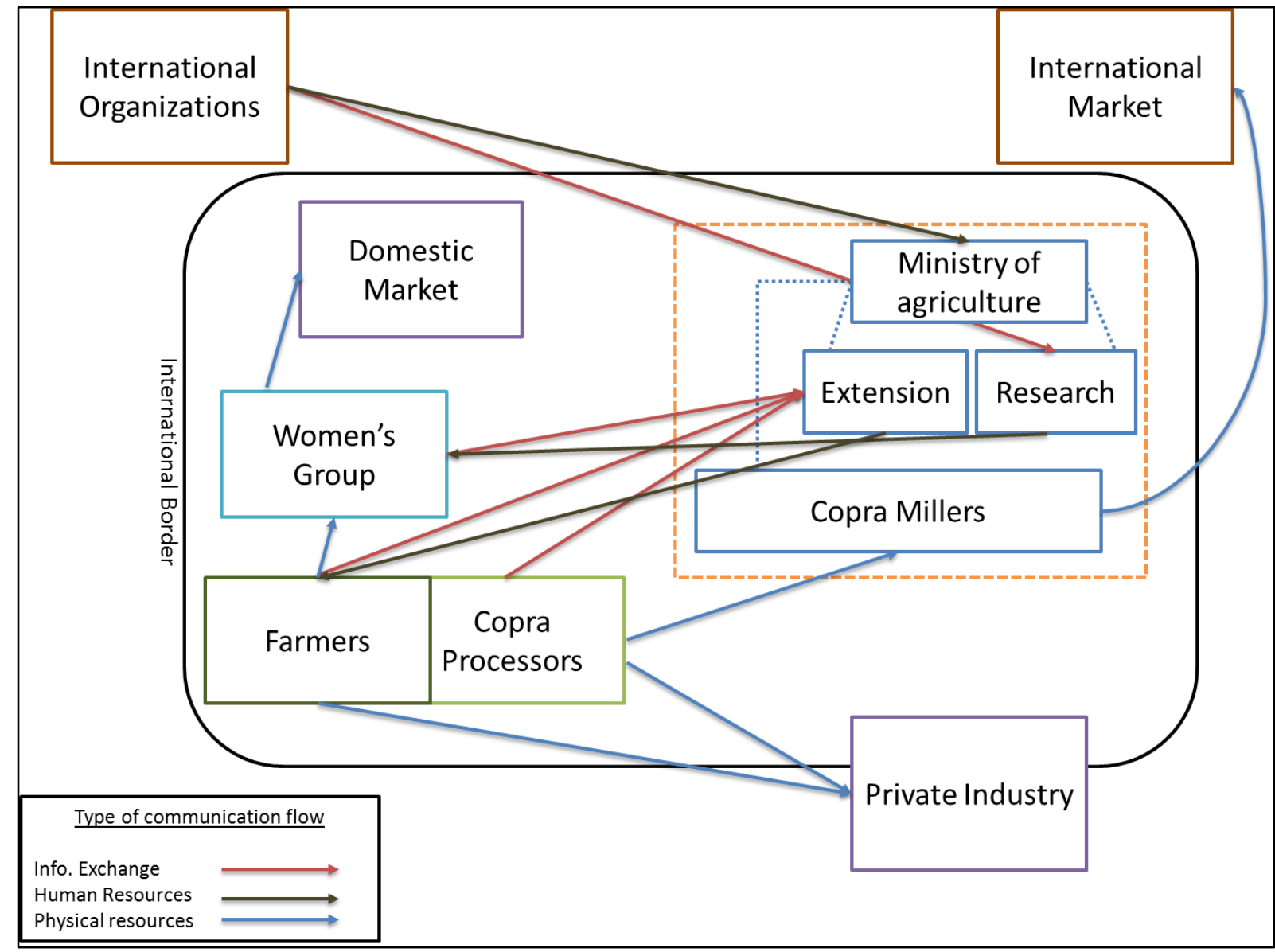

Fig. 3.6: Communication network diagram of key stakeholder groups in Fiji's coconut sector

The extension team also selects the participants for VCO training while the members from the research divisions conduct training with the selected participants. "We don't do the selection. The extension division selects, and we train. Extension officers are the bridge between farmers and the research division, we don't communicate with the farmers" (Researcher, MOA). Furthermore, extension agents claim to have distributed seedlings to farmers for replanting strategies. Yet, most farmers interviewed claimed to not have received any seedlings from them. We can observe that communications with international actors take place with actors in the Ministry in the form of information exchange and human resources. However, the main decision-making bodies do not exchange information with farmers nor women's groups. 
International organizations, namely, the Pacific Community (SPC), an international organization that has a dominant presence in the Pacific Islands, implements and plans projects via the Ministry. However, no communication is observed between them and the farmers.

There appears to be a lack of communication among the different groups of stakeholders according to the interviews. Thus, the challenges facing the industry are perceived differently by each group. The centralized government figures are detached from the farmers and VCO makers. Furthermore, there is a fear to challenge authorities. "Fiji is suffering from personality politics. If you disagree with them, you are regarded as the enemy. Everything becomes personal" (Private consultant, Suva).

The interviews and stakeholder mapping generated a broad range of perspectives on the challenges to Fiji's integration into the international coconut value chain.

\section{Identifying perceived challenges and opportunities}

For all farmers interviewed, coconut production is only one of several income sources. Other farming activities include kava and taro, livestock keeping, and fishing. Due to the high prices of kava and taro, much of the land and labor in Taveuni is now used for these two crops. Compared with coconuts, these crops do not require large areas of land and length of time until harvest, making them more attractive to cultivate. Furthermore, unlike coconuts, there is no additional labor required after harvest to sell kava or taro. "Right now, kava and taro are getting more money than copra, so no one wants to make copra" (Estate manager, Taveuni). According to interviews with farmers and managers, there is currently no copra production in Taveuni after the destruction of Hurricane Winston in 2016. Only one foreign farmer is investing in growing coconuts and investing in the value-added technologies needed for entering the international virgin coconut oil market. His production is in the initial stages, and therefore, the outcome will not be observed for several more years.

Table 3.4 presents an overview of the most often stated perceived challenges by each stakeholder category. The results show that respondents from the Ministry name mostly senile trees as the main challenge. Conversely, farmers and researchers state a lack of diversified markets and low copra prices as their points of concern. Because of diverging perceptions, parties also have different views to address the constraints. Of all the farmers we interviewed, not one has participated in the government scheme of replanting either because they did not know about it or they did not receive any seedlings. We also observed during field visits that piles of coconut seedlings are left on the side of the road, unused and germinated. 
Table 3.4: Perceived challenges by each stakeholder category

\begin{tabular}{lll}
\hline Stakeholder Category & Perceived Challenges & Perceived Opportunities \\
\hline Ministry of Agriculture & Senile trees & Replanting \\
International & Knowledge, supply & Global demand \\
Private & Lack of market & Increasing awareness \\
Farmer/VCO Processor & $\begin{array}{l}\text { Prices, transportation, market, } \\
\text { competing crops }\end{array}$ & markets market; possible \\
\hline
\end{tabular}

There are additional constraints stated by the respondents. The government provides machines to local women's groups in the form of the production of VCO. However, one member of the women's group remarked that their main obstacle is the lack of electricity. She commented that it is difficult to convince other members to cooperate together to make VCO due to the lack of electricity generators in the village (Women's group member, Savusavu). With no access to power, production is restricted. There are no functional farmer organizations that exist to coordinate production on a larger scale. Farmers and women group members work in parallel with each other within the same village. We did not observe any coordinated production among the villages.

A university professor questioned the qualifications of extension officers. "They might be generalists in vegetables, but we need coconut experts. The resources that have been diverted have not transformed into outcomes" (Academic, Suva).

In the land tenure system, there is still a possibility to lease land to private investors. However, much of this land, in particular, the plantations are leased to foreign investors who prioritize immediate profits. After Hurricane Winston struck in 2016, many coconut plantations remain damaged and unrestored. "This place is owned by a Malaysian based in Hong Kong. They don't want to spend money to refurbish these estates. Whatever money we get is only to develop the estates according to what they want to do..." (Estate manager, Taveuni).

Recently, there have been efforts to promote the production of VCO, which is believed to be able to bring in a premium price. However, governmental efforts go little beyond training local women's groups to make VCO and other by-products. There is no follow-up or coordination among the groups who attended the training. VCO generates the highest price, however, the production is done on a very small scale and not widely promoted. VCO producers also comment that they do not have enough supply of coconuts nor labor to have a larger production. One leader of the women's group comments that if they had a larger production, then they could have their VCO tested for quality at the Koronovia research center located in Suva. 
The pricing of coconut oil, together with no knowledge of other value-added products is a major concern. "Farmers don't know the end product of copra, only oil. We don't really know what they do with the copra and who they sell to... Right now, with the price, people are happy, but it would be better if the prices are higher. The process is difficult with cutting and drying. If the prices can go up, then we can't complain much" (Farmer, Savusavu).

When asked about whether there is awareness of products beyond copra and coconut oil, our interviews show that the majority of farmers and local government officials have no knowledge of coconut products other than copra and oil. Some mention coconut water for direct consumption locally, but knowledge of packaged coconut water for export is limited.

Despite the constraints mentioned by the farmers, they all stated to have a positive outlook on the coconut industry. Many farmers comment that coconut palms have been planted by their forefathers and have always been a part of their lives. The domestic market is good if whole nuts, instead of dehusked nuts are sold. Farmers expressed willingness to sell whole nuts if they have access to transportation. As already shown in table 2, selling whole nuts is more profitable than selling copra. Overall, there is a consensus to continue coconut harvest and copra production. "Prices are increasing" (Farmer, Savusavu). This could be a key factor, especially if and when prices of kava and taro start to decrease.

Respondents from the government perceive replanting nuts for the future outlook. If massive replanting efforts are undertaken, then a future supply of nuts would be secured. International researchers observe that the international market is growing, therefore the potential to produce the products is there.

Members of the women's groups do see a good future with producing VCO. "Doing VCO is easier than extracting kernels to make copra. It produces more income than copra. Before, we used to make copra, but now, we are making VCO and soap out of VCO” (Women's group member, Savusavu). The link to tourism is a starting point of having increased production and quality testing. Members of the women's group already sell VCO to high-end resorts and tourists from cruise ships. This is a market that has the potential to be expanded. If there is a demand for exports, Fiji already has direct transportation linkages to major Pacific Rim markets that can be utilized. Many comments that there are opportunities especially if private companies are involved. If larger companies become involved, they could provide the backbone of the industry and also serve as alternatives to Copra Millers.

\subsection{Discussion}

Our empirical analysis shows that voice and accountability and especially government effectiveness increase coconut exports from Fiji where the effective size of the latter is much 
larger. This highlights the government's ability to enforce contracts and the ability to provide complementary services that are needed during international exchanges. The rights and bargaining power of citizens also have a positive effect on coconut exports from Fiji. On the other hand, control of corruption decreases exports. This finding supports the "grease the wheel" reasoning discussed by Ben Ali and Mdhillat (2015) in which more corruption could ease bureaucratic procedures that arise during bilateral exchanges. For example, bureaucrats often bribe officials at customs to avoid complicated bureaucratic procedures (Ben Ali \& Mdhillat, 2015). Dreher and Gassenbner (2013) further contend that the effects of weak policies could be eased by corruption by stimulating economic activities. Our interviews do not reveal the entry points for corruption to take place. Given that there are no formal or bureaucratic procedures until the export of crude coconut oil stage in the supply chain, we speculate that it is in this later segment in the value chain that corruption could ease exporting procedures.

These findings give us a glimpse into the big picture of the role of institutional quality. To further scrutinize and understand the storylines to understand the perceived opportunities and challenges of Fiji's global integration in its relation to the role of institutions, we discuss our results from our qualitative interviews.

The coconut value chain in Fiji is simple and shorter compared to other larger producing countries, given that there are fewer market outlets. This process is labor-intensive. At the same time, the monetary returns have stayed consistently low. These reasons, together with the communal land tenure system, mean that farmers have little incentive to replant and to invest time and care for coconut groves. In contrast to the Philippines, for example, farmers sell whole nuts to either the village agent or town trader. From there the nuts are sold to different retailers and processors of various products (Pabuayon et al., 2009). Different actors are involved at different stages of the value chain, thus, not all farmers need to dehusk and process coconuts into copra themselves. This value chain has less labor involved for the farmers and more buyers and market outlets. Fijian farmers do not necessarily need to take part in the high-value processing in order to benefit. As many farmers remarked, since making copra is highly laborintensive, it is possible that the opportunity to sell whole nuts could incentivize them to replant and manage coconut groves. This would also ensure that copra quality is consistent as there would be fewer copra processors. High-value and niche markets could also create demand for the buying of whole nuts from farmers and villagers. In this case, Fiji could benefit from the involvement of the private sector to link the knowledge and capital that is necessary for the development of niche markets (Juswanto \& Ali, 2014). 
Because each farmer essentially acts alone in the production of copra, it is difficult to achieve economies of scale since production is at an individual level. The linkages to markets could be realized through organizational upgrading, where farmers self-organize at the production level to realize economies of scale (Abdulsamad, 2016).

We observe in the results that the lack of two-way communications among key actors leads to a difference in perceptions of problems encountering Fiji's coconut sector. This result shares findings of social network theories that state similar groups are more likely to share similar views (Prell et al., 2009). At the same time, actors don't necessarily communicate better in terms of complex information and tasks. The decision-makers in the Ministry as well as the international organizations that implement projects are detached from the people who are harvesting and processing coconuts. The strategies from the government have not worked due to a lack of understanding of why farmers do not replant. While many government officials and international researchers perceive senile trees as a major threat, none of the farmers mentioned this factor. Extension officers do not engage in information exchange actively with farmers to comprehend the viewpoint of farmers and women's groups. Our results echo research by Bijman et al. (2012) and Pouton et al. (2010) that integrating smallholders into agricultural value chains requires coordination of the network of actors involved. The role of formal institutions must be realized. International institutions involved with research can extend their communication to farmers and villagers as well as facilitating dialogues between the government and the producers.

Similar to a study by Neilson and Shonk (2014) on coffee production in the Toraja region of Indonesia, Fijian farmers have little incentive to prioritize coconut production since it is only produced for complementary subsistence and efforts into managing coconuts are not obvious paths towards wealth in the future. Returns to planting coconuts are not immediate; palms usually take up to five years before nuts can be harvested. The environment created by the historical developments of Fiji's coconut sector and the country's land ownership system limit both the individual and institutions' incentives to put in further development and innovations. Foreign investors want immediate returns, therefore, they have no interest in developing and managing existing coconut plantations. Instead, their focus is planting kava and taro on these same plantations. It is possible that farmers do not realize that decreasing the productivity of the palms is becoming an issue as some respondents mention that coconut palms have always been there, as a part of their life. The farmers must see the value themselves for replanting.

The interviews reveal that farmers are dependent on the government mill as a market outlet. They also express the need for more market opportunities and higher prices. Similar to the 
findings of Angelucci and Conforti (2010), small farmers from Caribbean and Pacific Island countries state a lack of established institutions to spread information on market opportunities and facilitating access to financial and supply services and inputs. The same authors also find that small farmers in Fiji tend to be more concerned with price volatility. If there exist a stable business climate and consistent price, farmers would be motivated to invest in production and quality standards (Ponte \& Gibbon, 2005).

Our results show that there is a lack of coordination and cooperation in both copra production and VCO production. If farmers can self-organize on the primary production level via farmers groups or cooperatives, then they could consolidate the processing of copra. Villages can work together, instead of in parallel to another. This way, each farmer would not have to bear this burden on himself. With the set-up of small copra processing centers around villages, Copra Millers could send trucks to these centers and transport copra back to the mill, easing the transportation constraint on farmers. Similarly, women's groups can work together in combining their production on a larger scale. This makes it more possible for the groups to have their end-products tested for quality standards at the research station located near the capital city of Suva.

Food safety practices remain a major roadblock for the integration of many coconut products. For Fiji to develop a coconut industry with higher value addition, farmers and processing units need to meet international food safety standards, such as the Codex Alimentarius or the Hazard Analysis and Critical Control Point (HACCP). In addition to food safety, standards, and certifications that address labor and environmental issues are often required for many coconut products, especially those in niche markets. The knowledge must be spread and efforts implemented. Fiji currently does not have any type of standards that guarantee the quality of VCO. Without safety standards and private standards and certifications, it is difficult for Fiji to compete with other bigger producing countries with an already established and more sophisticated industry.

To set up larger-scale processing centers, there must be strategies to ensure that there is a consistent supply of good quality nuts and copra. The Ministry is not wrong when addressing programs of declining production and aging trees. Especially when coconut processing plants are set up, there must be a consistent supply. At the same time, there is hardly any motivation among producers to plant one million trees, as the ministry is targeting, when there is no market to sell those extra nuts. 


\subsection{Conclusion}

Studies to date suggest that small and remote countries have much to gain by integrating into the global value chain, such as increases in specialization, economies of scale, and income (Breisinger et al., 2019; Kowalski et al., 2015; Streeten, 1993). We add to the literature by looking into a specific case study and exploring the opportunities and challenges to the Fijian coconut sector by using a mixed-methods approach. We first assess Fiji's coconut exports based on three of the World Bank's world governance indicators. We conduct field research in three regions of Fiji to interview different stakeholder groups in the coconut sector. The goal is to assess the perceptions of each group. We map out a communications network diagram that shows the relationships and forms of communication that actors in the value chain have with each other. We then identify the perceived challenges and opportunities according to each stakeholder group.

Our findings suggest the challenges that face Fiji's integration into the global market are multifaceted. On a macro-level, giving voice and rights to citizens and increased government effectiveness increase Fiji's export of coconut products.

The existing value chain is rudimentary and limited to low-value products such as copra and crude oil. Though much of the crude oil is exported, it brings very little return to those who are involved in coconut production. The existing land tenure system further disincentives smallholders to invest time and energy in managing coconut groves and replanting. Access to high-end international markets remains restricted due to a lack of diversification and innovation in products. The exchange between major stakeholder groups is fragmented. The main decision-makers and international organizations that fund coconut development projects do not directly communicate with people who are involved with the collection and production of coconuts. Each group perceives that challenges facing the industry very different and this creates different incentives in where each stakeholder is willing to put forth efforts.

The situation in Fiji is not dissimilar than those in neighboring island nations. Fiji is in a more advantageous situation as it already has established markets in developed nations such as Australia and New Zealand. It might seem obvious to assume that one of the main reasons why Fiji, along with other Pacific Island nations, cannot integrate into the global coconut value chain is due to its natural geographic situation. However, one of the most successful non-alcoholic drinks in the world, Fiji Water, was able to break through this barrier to enter the competitive international market. Due to the isolation of Fiji's location and its association with being a tropical paradise, the water brand has defied constraints such as high transportation costs. The rising popularity of Fiji water shows an emerging preference towards distinctive taste and 
quality associated with a geographical region (Connell, 2006). This demonstrates that remoteness and small economies might be constraints, however, with the right innovation and investment climate, there is a possibility for industries to enter the world market. This same idea could be applied to coconut products from Fiji. The small size of Fiji and its isolation to the rest of the world is not enough to justify why the sector has not thrived on a global scale. The findings of this study could be of benefit to many of the Pacific Island countries. Coconut is a crop that needs to go through multiple stages of transformation before it can be utilized or consumed. Items cannot be produced without the know-how and institutional support along the value chain. There need to be mechanisms in place to create a conducive environment to diversify products that can come out of nuts. In order for the coconut industry to benefit from the current coconut market boom, Fiji needs efforts and support from several sectors. The islands are naturally endowed with coconut palms and smallholders have generations' worth of knowledge in cultivation and copra production. At the same time, an understanding of each party in the value chain and an effort to work together is crucial for the industry to enter the global market. The demand for traditional and niche coconut products is well established. By having the appropriate institutional support and facilitation in place, there is potential for farmers and processors in Fiji to reap more benefit from this versatile crop. 


\section{Modern agricultural value chains and food security of urban consumers in developing countries}

The efficiency of these farms versus large commercial farms relative to large commercial farms has been the subject of considerable research. Yet, no study has looked at the links between domestic agricultural commercialization and food security. This research fills the gap in the literature by assessing the effects of a transition of rural smallholder farming to selling or renting landholdings and supplying labor to larger commercial farms on the food security and economic welfare of in-country urban consumers. We model the ability of commercialized domestic agriculture to lower the price of traditional staple crops. We take price elasticities of demand for staple commodities from 15 studies conducted in several low-income countries and embed a demand-side framework into the Ma-Sexton model to study the impacts of land consolidation and the onset of commercial farming systems on the dietary diversity and economic welfare of both smallholder farmers and urban consumers.

Keywords: Staple crops, food demand, urban consumers, land and labor institutions, modern agricultural markets, smallholder farms

JEL Classifications: O13, Q11, Q15, Q18

This paper is a work in progress. This chapter is co-authored with Dr. Melin Ma (MM) and Prof. Richard Sexton (RS). The contributions of each author are as follows: Jessie Lin (JL) and RS conceptualized and designed the research. The literature and data were gathered by JL. The model was conceptualized by MM and RS while the simulation was done by MM. The writing was done by JL and MM with the assistance of RS. 


\subsection{Introduction}

In most developing countries, small-scale family farming systems remain the pillar of the agricultural economy. In the last several decades, the average farm size in most developing countries has decreased (Adamopoulos \& Restuccia, 2014; Hazell et al., 2010; Lowder et al., 2016; Riggs et al., 2016). The efficiency of these farms, mostly under two hectares, relative to large commercial farms, has been the subject of considerable research and debate. Findings by Barrett et al. (2010) show that compared to larger-scale farms, smallholder farmers do achieve the inverse product-size relationship. However, others argue that much of this relationship could be attributed to estimations that differ qualitatively, the erroneous definition of productivity (Sanchez et al., 2019), and biased by limitations due to information asymmetry (Carter \& Zimmerman, 2000; Zimmerman \& Carter, 2003).

Smallholder farming has received much institutional support due to some evidence that highlights the importance of smallholder farms if agriculture is to play a role in development and poverty reduction (Birner \& Resnick, 2010; Diao et al., 2007). Part of India's initiatives to double farmer's income by 2022 (Srikala, 2020) further emphasizes the imperative shared by governments and international organizations. These strategies aim more towards sustaining small farmers rather than enabling them to transition out of farming and into supplying inputs to commercial operations.

The commercialization and consolidation of farms affect smallholders. Recent studies have shown that the food security status of farm households have increased from participation in modern agricultural supply chains (Bellemare \& Novak, 2017; Montalbano et al., 2018). However, much of this current research has focused on high-value export products. The implications of these studies are important, however, there has been little attention paid to their effects via staple food markets for in-country urban consumers. Carbohydrates in the form of cereals and tubers remain the primary staples for many developing countries. Upgrading staple commodity chains could alleviate poverty and food insecurity more than the development of high-value commodity chains (Diao et al., 2012). For example, Maertens and Vande Velde (2017) find that contract farming in the rice sector in Benin leads to an increase in income and higher productivity benefits for farmers. Experimental studies by Demont and Ndour (2015) in African markets show that upgrades in the rice value chain increase the opportunities for rural farmers to connect with urban markets. We contribute to the literature by shifting the focus to the links between agricultural commercialization and the dietary diversity of domestic urban inhabitants. We do so by building on a model developed by Ma and Sexton (forthcoming). 
Their framework modeled a hypothetical setting in which supportive institutions enabled smallholder farmers to terminate farm operations to supply land and labor inputs to larger commercialized farms. The model allowed for the labor efficiency advantage of small farms, but incorporated capital constraints and disadvantages in the output market. Household incomes and total production output were compared to a setting in which farms continued under smallholder production. Their findings show that even accounting for labor efficiency on smallholder farms, supplying inputs and labor to large commercial farms leads to higher incomes and larger production outputs compared with working on own small farms across a wide range of plausible market settings.

This paper addresses the model's unanswered questions of how this productivity effect can influence the welfare of domestic consumers if the increased output is directed towards staple commodities sold in the home country markets in the following dimensions. We model the ability of commercialized domestic agriculture to substantially lower the price of traditional staple commodities. Not only can this increase the consumption of the staple, but it can also generate a substantial income effect given the importance of the staple in poor consumers' budgets.

The organization of this paper is as follows: the next section reviews the literature regarding the relative efficiencies of small-scale and commercial farming in developing countries and the relationship between agricultural production and food security. Section 3 introduces the conceptual model of smallholder transformation and domestic food markets. In section 4, the model is parameterized based on the empirical literature on price elasticities of demand. Section 5 presents the simulation results, and section 6 concludes with a discussion on the policy implications.

\subsection{Background}

\section{Relative efficiencies of small-scale and commercial agriculture in low-income countries}

The inverse relationship between productivity and farm size has been widely studied in developing countries. The literature thus far has conflicting views on this relationship. Explanations that support this hypothesis center around the relative inefficiency of hired labor (Feder, 1985) and imperfect markets (Barrett et al., 2010; Heltberg, 1998). The opposite viewpoints contend that commercial farms receive higher prices than smallholder farms. Reasons could be several: (i) better access to information for commercial farms (Courtois \& Subervie, 2015), (ii) smallholders are more exposed to the buyer market power due to limited 
selling opportunities (Mitra et al., 2018), and (iii) receive discounted prices due to limited sales volumes (Poulton et al., 2010).

Smallholders are also often credit constrained, thus limiting their ability to obtain market inputs (Sial \& Carter, 1996). Guirkinger and Boucher (2008) find that productivity levels of creditconstrained households are related to their land and liquidity endowments. Their study in Northern Peru finds that the value of output per hectare increased by 26 percent when credit constraints were removed in the formal sector (Guirkinger \& Boucher, 2008).

$\mathrm{Ma}$ and Sexton (forthcoming) build a model of a rural economy that attempts to quantify these factors and compare rural household income under smallholder framing with a hypothetical scenario in which farms are able to consolidate and rural households supply land and labor inputs to the commercial farms. The model accounts for the labor-efficiency advantage of smallholder farms to commercial farms, and also smallholders' disadvantages in terms of selling prices and access to market inputs. The less the loss of labor efficiency by large farms and the more constricted the smallholder's credit constraints, the larger is the income advantage from supplying labor and land to commercial farms compared to operating on small farms (Ma \& Sexton, forthcoming).

The Ma-Sexton model is limited in that it assumes output price is not a function of output quantity in the local economy, thereby making their model applicable mainly to export commodities, wherein the local economy represents a "small country" price-taking exporter. Their paper, thus, leaves unaddressed the essential question of how productivity improvements for important non-tradeable staple crops might improve the welfare of not only the rural producing households but also of urban consumers. This paper studies this question. The MaSexton model is extended to incorporate that output price is affected by the domestic supply, i.e., demand for the staple is downward sloping with an elasticity that is parameterized from the empirical literature and that varies across commodities and country settings.

\section{Agricultural production and food security}

Food demand differs according to income levels. Engel's law states a family's budget share of food decreases as its income rises. As household income grows, an increase of a lesser proportion in the household's budget would be allocated to food expenditure. Though higher income is often associated with an increase in consumption of high-value foods, we know very little about the changes in consumption for staple commodities, such as cereals (Mottaleb et al., 2018), especially in urban households. 
Around 97 percent of urban citizens are net food buyers (FAO, 2008), who rely largely on household income for food consumption (Ruel et al., 2010). In low-income countries, around half of available calories come from cereals, meaning that a decrease in cereal prices would have a big effect on people's diet relative to a price decrease in other food groups (Cornelsen et al., 2015). Though some literature suggests that in many developing countries, urban consumers are substituting consumption of staples towards animal proteins, dairy, fruits, and vegetables (Muhammad et al., 2011; Minten et al., 2017), it is difficult to distinguish whether the changing food consumption pattern is due to rising incomes or urbanization.

Poor households tend to prioritize food that is denser in calories over the quality of food (Tefft et al., 2017) thus spending a considerable share of their income on staple foods (Mason et al., 2011). For example, in Zambia, though there is a trend towards changing diets, the share of staple crops remain high for those living in poverty (Mason \& Jayne, 2009). In Niger, the lowest income quintile spends around 60 percent of its food budget on staples, compared to 44 percent for the highest-income quintile (Hollinger and Staatz, 2015). Furthermore, Alem and Soederbom (2018) find that urban Ethiopian households continue to consume teff, a local staple crop, as a main source of carbohydrate in their diet even when the price of teff has increased. In India, price elasticities are lower for richer households compared to poorer households (Kumar et al., 2011). These studies imply that the majority of the urban poor continue to devote a large share of their expenditure to staple food, thus, they become vulnerable when there is an increase in food prices (Ivanic \& Martin, 2008). Additionally, if, as these studies suggest, a price hike in staple food acts as a fall in income for urban inhabitants, then equally, a significant decrease in prices of staple goods would increase the purchasing power for the same group of people.

The consumer's response to price changes in a staple food is based on their relation to the prices of other items he or she purchases, and the consumer's budget or income (Dorward, 2012). A change in the price of food can either drive consumers to substitute within the same food group or to a different category of food (Skoufias et al., 2011).

First, via the income effect, a price decrease serves as an implicit increase in real income, enabling consumers to spend this extra "income" on other foods. For instance, in the Sahelian region of Africa, as net buyers of millet and sorghum, urban households suffer a fall in real income when price increases in these staples (Haggblade et al., 2017). If the staple has a lowincome elasticity compared to other food groups, then the income effect is small for the staple but larger for other food groups, such as fruits, vegetables, and animal proteins, which have greater income elasticities. In Kenya, food security and diet quality are improved through higher 
incomes gained through commercialization (Ogutu et al., 2019). In response to higher prices in starchy staples, consumers in West Africa respond by cutting back on diet quality, reducing consumption of fruits, vegetables, and animal protein (Hollinger and Staatz, 2015). Colen et al. (2018) find large differences in income elasticities among food groups in Africa with higher elasticities for animal protein and dairy compared to other food groups. When food expenditure increases, poorer households substitute their staple intake towards higher-quality foods (Skoufias et al., 2011).

Second, via the substitution effect, buyers will increase their consumption of the staple as its price is now relatively cheaper than other foods. For example, research by Skoufias et al. (2011) in Mexico reveals that given an increase in per capita expenditure, a large share of poor households substitutes within cereal groups. In Malawi, increasing incomes is associated with higher demands for staples (Ecker \& Qaim, 2011). Jensen and Miller (2008) find evidence of Giffen behavior in the Hunan province of China, where an increase in unearned income leads to a decrease in rice consumption. This negative income elasticity for the staple means that all of the income effect created by the price reduction goes to diversifying the diet.

Table 4.1 shows the price elasticities of the staple food group from the literature. Price elasticities of demand from the literature indicate that an increase in price is negatively related to consumption. These numbers suggest that if prices were to decrease for staples, then consumption of the staple item would thus increase.

Table 4.1: Price elasticities of demand for staple crops in selected studies

\begin{tabular}{llll}
\hline Authors & Year & Country & Price elasticities \\
\hline Abdulai \& Aubert & 2004 & Tanzania & -1.03 \\
Ackah \& Appleton & 2007 & Ghana & -1.1 \\
Agbola & 2003 & South Africa & -1.73 \\
Akinleye \& Rahji & 2007 & Nigeria & -0.85 \\
Alfonzo \& Peterson & 2006 & Paraguay & -0.88 \\
Balisacan & 1994 & Philippines & -0.93 \\
Ecker \& Qaim & 2011 & Malawi & -0.80 \\
Jensen \& Manrique & 1998 & Indonesia & -0.62 \\
Kumar et al. & 2011 & India & -0.64 \\
Menezes et al. & 2008 & Brazil & -0.92 \\
Me-Nsope \& Staatz & 2016 & Mali & -1.02 \\
Nirmali \& Edirisinghe & 2015 & Sri Lanka & -0.71 \\
Ulimwengu et al. & 2009 & Ethiopia & -0.84 \\
Ulimwengu \& Ramadan & 2009 & Uganda & -0.41 \\
Ulimwengu et al. & 2012 & Dem. Rep. of Congo & -2.07 \\
\hline
\end{tabular}


In addition, income and expenditure elasticities are lower in these countries relative to other food groups as shown in table 4.2, suggesting that as income increases, consumers spend relatively less on staples and more on animal protein and dairy products (Abdulai et al., 1999). In urban India, cereals and pulses have an expenditure elasticity of 0.48 compared to 1.14 for meat, fish and eggs, and 1.40 for milk products(Abdulai et al., 1999). Similarly, in Tanzania and Malawi, expenditure elasticities of meat, fish, eggs, and dairy products are higher than one whereas cereals and pulses have elasticities of less than one (Abdulai \& Aubert, 2004; Ecker \& Qaim, 2011).

Table 4.2: Budget shares for staples and income/expenditure elasticities of staples vs. animal proteins in urban areas from selected studies

\begin{tabular}{lllllll}
\hline Authors & Year & Country & $\begin{array}{l}\text { Budget } \\
\text { Shares } \\
\text { for } \\
\text { staples }\end{array}$ & $\begin{array}{l}\text { Expenditure } \\
\text { elasticities for } \\
\text { staples }\end{array}$ & $\begin{array}{l}\text { Expenditure } \\
\text { elasticities } \\
\text { Animal } \\
\text { proteins }\end{array}$ & $\begin{array}{l}\text { Fruits and } \\
\text { vegetables }\end{array}$ \\
\hline $\begin{array}{l}\text { Abdulai et } \\
\text { al. }\end{array}$ & 1999 & India & 0.19 & 0.48 & 1.27 & 0.89 \\
$\begin{array}{l}\text { Abdulai \& } \\
\text { Aubert }\end{array}$ & 2004 & Tanzania & 0.40 & 0.74 & 1.23 & 1.04 \\
$\begin{array}{l}\text { Ecker \& } \\
\text { Qaim }\end{array}$ & 2011 & Malawi & 0.37 & 0.8 & 1.27 & 0.31 \\
$\begin{array}{l}\text { Ulimwengu } \\
\text { et al. }\end{array}$ & 2009 & Ethiopia & 0.47 & 0.52 & 0.74 & 0.41 \\
$\begin{array}{l}\text { Ulimwengu } \\
\text { et al. }\end{array}$ & 2012 & $\begin{array}{l}\text { Dem. } \\
\text { Rep. of }\end{array}$ & 0.22 & 0.06 & 1.31 & 0.91 \\
\hline
\end{tabular}

These numbers suggest that traditional carbohydrate staples in these countries have a high budget shares but low-income elasticities to the point that the benefit from the higher real incomes generated by lower staple prices can contribute to expanding the consumption of other foods that could enhance dietary diversity and nutritional health of the poor urban households.

\subsection{Conceptual Model}

We consider a closed developing economy that contains an agricultural sector and a nonfarm sector. In the baseline equilibrium, its agricultural sector relies on a smallholder production system, employing all rural labor, and supplies the staple food for the entire economy. The nonfarm sector produces nonfarm products for all. In an alternative scenario, large-scale

\footnotetext{
${ }^{7}$ Animal protein refers to Meat, fish, eggs, and dairy products
} 
commercial farms emerge and produce staple food using land and labor provided by smallholder households. Our goal is to set up a conceptual model of smallholder and large-scale production with an endogenous price for the staple food and endogenously determined prices for farmland and farm labor.

In the baseline equilibrium, there are $\bar{N}$ households in the economy out of which $N=\bar{N} \phi$ are homogeneous "rural" households and $\bar{N}(1-\phi)$ are homogeneous "urban" households. We assume that rural and urban markets for farm and nonfarm goods are integrated. Specifically, consumer demand for staple food is $p^{r}=D(Q \mid Y)=a Q^{b}$ where $a>0$ and $b<0$. The demand elasticity is a constant of $\frac{1}{b}$. Let the demand for nonfarm good be elastic with a market price normalized to one.

Under smallholder production, the urban and rural prices of the staple food differ by a fixed percentage of marketing margin reflecting intermediaries' costs of processing and transporting the product. Thus, the price faced by smallholders can be expressed as $a \sigma_{S} Q^{b}$ where $\sigma_{S}<1$. Under large-farm production, a different fixed percentage of marketing margin applies. The price paid by rural households is $a \sigma_{L} Q^{b}$ where $\sigma_{S}<\sigma_{L}<1$. For simplicity, normalize $a \sigma_{L}=$ $\bar{a}$, and let $\frac{\sigma_{S}}{\sigma_{L}}$ be $\sigma<1$. The rural price under smallholder production can be expressed as $\sigma \bar{a} Q^{b}$ whereas under large-farm production is expressed as $\bar{a} Q^{b}$.

\section{Smallholder Production}

We consider a typical agricultural household model (Singh et al. 1986), where a rural household maximizes utility from consuming a composite nonfarm good $(x)$, the staple food $(z)$, and leisure ( $l$ ) under an endogenous budget equal to the net sales of farm outputs. The utility function is concave in the three goods and has first derivatives going to infinity if the value of consumption is zero. We treat the composite nonfarm commodity price as a constant and normalized to 1.0. Farm production is increasing in the use of land $(h)$, labor $(t)$, and "capital inputs" $(k)$. Capital inputs may, depending on the farm product, include seeds, fertilizers, herbicides, and equipment, i.e., they are inputs that have to be purchased through the market and prior to the harvest and the realization of farm income. Without loss of generality, we normalize the land and labor endowments of homogenous rural households to 1.0.

In the equilibrium, no land or labor is traded even with perfect factor markets due to the symmetry among rural households. The market price for capital inputs is $v$, and we allow for an imperfect credit market. Each household is hence constrained in using capital inputs by an 
exogenous budget constraint, $B$, which may reflect savings carried forward to the crop year and/or the available credit.

The smallholder problem is specified as follows:

$$
\max _{x, z, l, k} u(x, z, l)
$$

Subject to

$$
\begin{gathered}
x_{S}+p_{S}^{f} z_{S} \leq p_{S}^{f} f\left(h_{S}, t_{S}, k_{S}\right)-v k_{S} \\
v k_{S} \leq B \\
l_{S}+t_{S} \leq 1
\end{gathered}
$$

Choice variables $x, z, l, k$ are all nonnegative. To obtain analytical solutions, we specify the utility function as $u(x, z, l)=x^{1 / 3} z^{1 / 3} l^{1 / 3}$. Utilizing a Cobb-Douglas utility function with equal exponents and budget shares for its arguments greatly simplifies the exposition, but, of course, involves a loss in generality. We later relax this assumption and consider the implications for the analysis of heterogeneous budget shares.

Let the farm production function also be in the Cobb-Douglas form: $q_{s}=f(h, t, k)=h^{\alpha} t^{\beta} k^{\varepsilon}$, where $\alpha, \beta, \varepsilon \in(0,1)$ are the output elasticities for land, labor, and capital inputs, respectively. In addition, we follow the convention (e.g., Feder 1985; Eswaran and Kotwal 1986; Barrett et al. 2010) and assume constant returns to scale (CRS) in farm production, so that $\alpha+\beta+\varepsilon=$ 1.

In the equilibrium, the constraint on labor endowment is binding by the Kuhn-Tucker Theorem, so that $t_{S}^{*}=1-l_{S}^{*}$, where superscript $*$ indicates equilibrium values throughout the article. Given that $\alpha>0$, it will always be optimal for the household to fully utilize its land allocation, so $h_{S}^{*}=1$.

Denote the Lagrangian function as $\mathcal{L}$. The FOC for each choice variable implies that its marginal contribution to utility equals its marginal market value with $u_{i}$ representing the derivative of the utility function with respect to variable $i$ :

$$
\begin{gathered}
\frac{\partial \mathcal{L}}{\partial x_{S}}=u_{x}-\mu=0 \\
\frac{\partial \mathcal{L}}{\partial z_{S}}=u_{z}-\mu p_{S}^{f}=0 \\
\frac{\partial \mathcal{L}}{\partial l_{S}}=u_{l}-\mu\left(p_{S}^{f} \frac{\partial f}{\partial t_{S}}\right)=0 \\
\frac{\partial \mathcal{L}}{\partial k_{S}}=\mu\left(p_{S}^{f} \frac{\partial f}{\partial k_{S}}-v\right)-\Gamma v=0 .
\end{gathered}
$$


From (2) we have $\mu=\frac{u_{z}}{p_{S}^{f}}>0$, implying that the overall budget constraint is also binding. We rewrite (4), the FOC for the employment of capital inputs, as

$$
\begin{aligned}
& \mu\left(p_{S}^{f} \frac{\partial f}{\partial k_{S}}\right)-\mu\left(1+\frac{\Gamma}{\mu}\right) v=0 \\
\rightarrow & \left(p_{S}^{f} \frac{\partial f}{\partial k_{S}}\right)=\left(1+\frac{\Gamma}{\mu}\right) v . \quad\left(4^{\prime}\right)
\end{aligned}
$$

We focus on the case when the credit constraint is binding for smallholders, so $\Gamma>0$. From $\left(4^{\prime}\right)$ the marginal return to capital inputs for the credit-constrained farmer is, thus, larger than the market price, $v$. We define $\gamma=1+\frac{\Gamma}{\mu}>1$, so that the marginal return to capital inputs at the constrained optimum is $\gamma v>v$.

Thus, the parameter $\gamma$ measures the magnitude of the credit constraint facing smallholder farmers, where the larger is $\gamma$, the less efficient is the allocation of capital inputs on smallholder farms. An alternative but conceptually equivalent interpretation emerges for settings where smallholders are unable to access formal lending institutions and instead receive credit at a higher rate from an informal lending sector. Define $v$ as the interest rate offered through the formal sector and $v^{\prime}>v$ as the rate available through the informal sector, then $\gamma=\frac{v^{\prime}}{v}$.

Dividing (2) by (1), we find that $x_{S}=p_{S}^{f} z_{S}$, reflecting the equal-budget-shares property of the utility function. Thus, the binding budget constraint implies that

$$
2 p_{S}^{f} z_{S}=p_{S}^{f}(1-l)^{\beta} k_{S}^{\varepsilon}-v k_{S} .
$$

Dividing (3) by (2), we express consumption of the staple food as a function of leisure:

$$
z_{S}=l_{S} \beta\left(1-l_{S}\right)^{\beta-1} k_{S}^{\varepsilon} \text {. }
$$

Substituting expression (6) into (5), we have

$$
v k_{S}=p_{S}^{f} k_{S}^{\varepsilon}\left(1-\frac{2 \beta l_{S}}{1-l_{S}}\right) .
$$

Rewriting equation $\left(4^{\prime}\right)$ with $\frac{\partial f}{\partial k_{S}}=\varepsilon k_{S}^{\varepsilon-1}\left(1-l_{S}\right)^{\beta}$ gives

$$
v k_{S}=\frac{\varepsilon}{\gamma} p_{S}^{f} k_{S}^{\varepsilon}\left(1-l_{S}\right)^{\beta}
$$

Equating equations (7) and (8), we find that the optimal amount of leisure, $l_{S}^{*}$ depends on parameters $\gamma, \varepsilon$, and $\beta$ and ranges in $\left(\frac{1}{3}, 1\right)$ :

$$
l_{S}^{*}=1-\frac{2 \beta}{1-\varepsilon / \gamma+2 \beta} .
$$

It follows that the optimal amount of labor input into farming is 


$$
t_{S}^{*}=1-l_{S}^{*}=\frac{2 \beta}{1-\varepsilon / \gamma+2 \beta} \in\left(0, \frac{2}{3}\right)
$$

Labor input is increasing in its own output elasticity and decreasing in the inefficiency of credit markets (i.e., higher $\gamma$ ), with that effect scaled by capital's output elasticity, $\varepsilon$.

To determine the optimal use of capital inputs, we first find the equilibrium consumption of staple food by urban households, $Q_{S}^{U *}$.It equals the total staple production, $Q_{S}^{*}=N\left(k_{S}^{*}\right)^{\varepsilon}(1-$ $\left.l_{S}^{*}\right)^{\beta}$, minus the rural consumption, which is found by substituting $l_{S}^{*}$ into (6):

$$
Q_{S}^{U *}=Q_{S}^{*}-N z_{S}^{*}=\frac{1+\varepsilon / \gamma}{2} Q_{S}^{*}
$$

Given the inverse urban demand function, $p_{S}^{f}=\sigma \bar{a}\left(Q_{S}^{U}\right)^{b}$, the farm price of staple food in the smallholder-farm equilibrium is expressed as:

$$
p_{S}^{f *}=\sigma \bar{a}\left(\frac{1+\varepsilon / \gamma}{2} Q_{S}^{*}\right)^{b}
$$

By substituting $l_{S}^{*}$ and $p_{S}^{f *}$ into (8) and replacing $Q_{S}^{*}$ in $p_{S}^{f *}$ with $N\left(k_{S}^{*}\right)^{\varepsilon}\left(1-l_{S}^{*}\right)^{\beta}$, we derive $k_{S}^{*}$. The expression of $k_{S}^{*}$ is markedly simplified by setting $b=-1$ (unit demand elasticity). ${ }^{8}$ Imposing this assumption yields:

$$
k_{S}^{*}=\frac{2 \bar{a} \sigma \varepsilon}{(1+\varepsilon / \gamma) \gamma v N} .
$$

$k_{S}^{*}$ is increasing in capital's output elasticity, urban consumer demand, and the small-farm share of retail value and is decreasing in $\gamma$.

Finally, we substitute equilibrium values for $k_{S}$ and $l_{S}$ into (6) to obtain the equilibrium smallholder consumption of staple food. Equilibrium consumption of the composite commodity follows immediately from the equality of its budget share with the staple food's share:

$$
\begin{gathered}
z_{S}^{*}=\frac{1-\varepsilon / \gamma}{2}\left(\frac{2 \beta}{1-\varepsilon / \gamma+2 \beta}\right)^{\beta}\left(\frac{2 \bar{a} \sigma \varepsilon}{(1+\varepsilon / \gamma) \gamma v N}\right)^{\varepsilon}, \\
x_{S}^{*}=\frac{\bar{a} \sigma(1-\varepsilon / \gamma)}{(1+\varepsilon / \gamma) N} .
\end{gathered}
$$

The farm-gate and retail prices are expressed by the urban consumers' inverse demand function:

$$
p_{S}^{r *}=\frac{\bar{a}}{\sigma_{L}}\left(Q_{S}^{U *}\right)^{-1}
$$

\footnotetext{
${ }^{8}$ This assumption is quite common in modeling (e.g., Costinot et al. 2016) and is a characteristic of log utility models, but of course, involves loss of generality. However, the literature on demands for staple foods in low income countries has an average elasticity from the surveyed papers being $\bar{\epsilon}_{p}=-0.88$. The demand elasticity for the staple for smallholders is also -1.0, given the Cobb-Douglas utility function, creating a symmetry between the urban and rural demands.
} 


$$
\begin{gathered}
=\frac{2 \bar{a}}{\sigma_{L}(1+\varepsilon / \gamma)}\left(\frac{2 \beta}{1-\varepsilon / \gamma+2 \beta}\right)^{-\beta}\left(\frac{2 \bar{a} \sigma \varepsilon}{(1+\varepsilon / \gamma) \gamma v}\right)^{-\varepsilon} N^{-(1-\varepsilon)}, \\
p_{S}^{f *}=\sigma \sigma_{L} p_{S}^{r *} .
\end{gathered}
$$

\section{Large Farm Problem}

We now consider an alternative scenario where smallholder farms are replaced through market processes by $M$ relatively large-scale farms. Assume that the large farms are homogeneous and sufficiently numerous so that they do not exercise buyer power in factor markets or the output market. Restrictions on the size to ensure competitive factor markets could be achieved through government policies. Taking market prices as given, each large farm chooses the optimal amounts of land, labor, and capital inputs to put into production. Land and labor inputs are provided to the large farms by smallholder households, and the competitive prices for these inputs are determined endogenously within the local economy. Rural households no longer selfsupply the staple and purchase it at retail according to the demand derived from their utility maximization problem. The price of capital inputs is $v$ and exogenous to the farms. We assume that one defining characteristic of a large farm is that it has capital reserves or access to formal capital markets and does not face a credit constraint.

We assume that the production function of large farms has the same structure as the smallholder production function. This assumption simplifies modeling, but, more importantly, it enables the model to focus on economic instead of technological differences between smallholder and large farms in terms of (i) staple-food price received, (ii) labor efficiency, and (iii) credit access. ${ }^{9} \mathrm{We}$ later relax this assumption and allow the large-farm technology to be more capital intensive and less labor-intensive and study the impacts of conversion to commercial farms on rural employment under this condition.

The objective function of a large farm is:

$$
\max _{h, t, k} \Pi=p_{L}^{f} f\left(h_{L}, t_{L}, k_{L}\right)-r h_{L}-w t_{L}-v k_{L} .
$$

We allow for a loss in labor efficiency on large farms due to the widely discussed and debated principal-agent problem with hired farm labor in low-income country settings (Feder 1985; Barrett et al. 2010; Sanchez et al. 2019). Specifically, the effective input of labor is $\omega \leq 1$ for each unit of labor hired on a large farm. Thus, $f\left(h_{L}, t_{L}, k_{L}\right)=h_{L}^{\alpha}\left(\omega t_{L}\right)^{\beta} k_{L}^{\varepsilon}$. We define $\Omega=$

\footnotetext{
${ }^{9}$ Another way to capture the differences in technological efficiency is to add multipliers to the production functions, but such differences have the same effect as the differences between $\sigma_{L}$ and $\sigma_{S}$.
} 
$\omega^{\beta}$, where $\omega$ is scaled by the importance of labor as a production input to capture the overall labor efficiency disadvantage of the large farm.

By symmetry of the equilibrium, we know that $h_{L}^{*}=\frac{N}{M}=n, t_{L}^{*}=n\left(1-l_{L}^{*}\right)$ where $l_{L}^{*}$ is the optimal amount of leisure of each smallholder household in the large-farm equilibrium, found by solving its utility-maximization problem, taking the market equilibrium wage rate, market land rental rate, and staple-food output price as given.

The utility-maximization problem of rural households is:

$$
\begin{gathered}
\max _{x, z, l} u(x, z, l) \\
\text { s.t. } x_{L}+p_{L}^{r *} z_{L}+w^{*} l_{L} \leq r^{*}+w^{*}
\end{gathered}
$$

With no missing market from the smallholder's perspective, the model is recursive. To solve this utility-maximizing problem, we first rewrite the budget of a smallholder household as a function of market equilibrium prices for land and labor. With competitive factor markets, these inputs' prices are equal to their marginal value products, $p_{L}^{f} \frac{\partial f}{\partial h_{L}}$ and $p_{L}^{f} \frac{\partial f}{\partial t_{L}}$, at the market equilibrium:

$$
\begin{aligned}
r^{*} & =p_{L}^{f *} \alpha \Omega n^{\alpha-1}\left(t_{L}^{*}\right)^{\beta}\left(k_{L}^{*}\right)^{\varepsilon}, \\
w^{*} & =p_{L}^{f *} \beta \Omega n^{\alpha}\left(t_{L}^{*}\right)^{\beta-1}\left(k_{L}^{*}\right)^{\varepsilon} .
\end{aligned}
$$

Given equal budget shares, optimal consumptions of the three goods are:

$$
\begin{gathered}
x_{L}^{*}=\left(r^{*}+w^{*}\right) \frac{1}{3}, \\
z_{L}^{*}=\frac{r^{*}+w^{*}}{p_{L}^{r *}} \frac{1}{3}, \\
l_{L}^{*}=\frac{r^{*}+w^{*}}{w^{*}} \frac{1}{3} .
\end{gathered}
$$

Substituting (9) and (10) into (12) and solving yields the optimal consumption of leisure:

$$
l_{L}^{*}=1-\frac{2 \beta}{1-\varepsilon+2 \beta} \in\left(\frac{1}{3}, 1\right)
$$

where $l_{L}^{*}<l_{S}^{*}$, meaning that rural households supply more labor in the large-farm equilibrium. The corresponding equilibrium labor input by each large farm is

$$
t_{L}^{*}=\left(\frac{2 \beta}{1-\varepsilon+2 \beta}\right) n
$$

To simplify notation, denote $\lambda=\frac{2 \beta}{1-\varepsilon+2 \beta}$ and $\lambda^{\beta}=\Lambda$. Given these equilibrium values for land and labor inputs, we can rewrite the large-farm objective function in terms of $k_{L}$ :

$$
\max _{k} \Pi=p_{L}^{f}\left(\Lambda \Omega n^{\alpha+\beta} k_{L}^{\varepsilon}\right)-r n-w(\lambda n)-v k_{L}
$$


The FOC of capital inputs implies that

$$
k_{L}^{*}=n\left(\frac{\varepsilon \Lambda \Omega p_{L}^{f}}{v}\right)^{\frac{1}{1-\varepsilon}} .
$$

From equation (11), we find that

$$
z_{L}^{*}=\frac{\sigma_{L}(1-\varepsilon)}{2}\left[\left(\Lambda \Omega n^{\alpha+\beta} k_{L}^{\varepsilon}\right) \frac{N}{n}\right]=\frac{\sigma_{L}(1-\varepsilon)}{2} Q_{L}
$$

Staple food consumed by urban households is the total production less the amount $z_{L}^{*} N$ consumed by rural households: $Q^{U}=\frac{2-\sigma_{L}(1-\varepsilon)}{2} Q_{L}$. Given the demand of urban households and with $b=-1$, the retail price paid by both urban and rural households is $p^{r}=\frac{\bar{a}}{\sigma_{L}}\left(Q^{U}\right)^{-1}$. Following a similar procedure to solving the smallholder problem, it then becomes straightforward to find the optimal amounts of capital inputs and consumption in the large-farm equilibrium:

$$
\begin{gathered}
k_{L}^{*}=\frac{2 \bar{a} \varepsilon n}{\left[2-\sigma_{L}(1-\varepsilon)\right] v N^{\prime}} \\
x_{L}^{*}=\frac{\bar{a}(1-\varepsilon)}{\left[2-\sigma_{L}(1-\varepsilon)\right] N^{\prime}} \\
z_{L}^{*}=\frac{\sigma_{L}(1-\varepsilon)}{2} \Lambda \Omega\left(\frac{2 \bar{a} \varepsilon}{\left[2-\sigma_{L}(1-\varepsilon)\right] v N}\right)^{\varepsilon}, \\
Q_{L}^{U *}=\frac{2-\sigma_{L}(1-\varepsilon)}{2} \Lambda \Omega\left(\frac{2 \bar{a} \varepsilon}{\left[2-\sigma_{L}(1-\varepsilon)\right] v}\right)^{\varepsilon} N^{1-\varepsilon}, \\
p_{L}^{r *}=\frac{2 \bar{a}}{\sigma_{L}\left[2-\sigma_{L}(1-\varepsilon)\right]}(\Lambda \Omega)^{-1}\left(\frac{2 \bar{a} \varepsilon}{\left[2-\sigma_{L}(1-\varepsilon)\right] v}\right)^{-\varepsilon} N^{-(1-\varepsilon)} .
\end{gathered}
$$

\section{Welfare Analysis}

The comparison of goods consumed by rural and urban households in the two equilibria is presented in Appendix A. Our key consideration is the welfare for rural and urban households under the two scenarios. To make the comparison, we need to quantity the welfare changes for urban and rural households. For urban households, we derive the equivalent variation $\left(E V^{U}\right)$ as the monetary value to an urban household of a price change for the staple food due to the change in the structure of the farm economy. Their incomes and prices of other goods stay unchanged. Let $e(p, u)$ be the representative urban consumer's expenditure function, and let superscripts 0 and 1 indicate the small- and large-farm equilibria, respectively. Then

$$
E V^{U}=e\left(p^{0}, u^{1}\right)-e\left(p^{1}, u^{1}\right) .
$$

If $p^{1}<p^{0}$, then $E V^{U}>0$ indicates that the monetary value of the price decrease to an urban household. Denote the price change of the staple as $\Delta p=p^{0}-p^{1}$. Then expanding $e\left(p^{1}, u^{1}\right)$ 
around the initial price and utility combination using a second-order Taylor's series approximation (Mas-Colell et al. 1995), we obtain:

$$
e\left(p^{0}, u^{1}\right)=e\left(p^{1}, u^{1}\right)+\frac{\partial e\left(p^{1}, u^{1}\right)}{\partial p} \Delta p+\frac{1}{2} \frac{\partial^{2} e\left(p^{1}, u^{1}\right)}{\partial p^{2}}(\Delta p)^{2}+\delta,
$$

Dropping the remainder term, $\delta$, in the series, $E V^{U}$ is expressed as

$$
\begin{gathered}
E V^{U}=\frac{\partial e\left(p^{1}, u^{1}\right)}{\partial p} \Delta p+\frac{1}{2} \frac{\partial^{2} e\left(p^{1}, u^{1}\right)}{\partial p^{2}}(\Delta p)^{2} \\
=z^{h}\left(p^{1}, u^{1}\right) \Delta p+\frac{1}{2} \frac{\partial z^{h}\left(p^{1}, u^{1}\right)}{\partial p}(\Delta p)^{2}
\end{gathered}
$$

where, via Shephard's Lemma, $z^{h}(\cdot)$ is the Hicksian demand for the staple food evaluated at the large-farm equilibrium. We can replace the unobserved Hicksian demand, $z^{h}\left(p^{1}, u^{1}\right)$, with the observed Marshallian demand, $z^{m}\left(p^{1}, Y\right)$, where $Y=e\left(p^{1}, u^{1}\right)$ denotes the consumer's money income because the two demand curves intersect at $\left(p^{1}, u^{1}\right)$.

We use the Slutsky equation to replace the unobservable $\frac{\partial z^{h}\left(p^{1}, u^{1}\right)}{\partial p}$ with observables from the Marshallian demand: $\frac{\partial z^{h}(\cdot)}{\partial p}=\frac{\partial z^{m}(\cdot)}{\partial p}+z \frac{\partial z^{m}(\cdot)}{\partial Y}$, and rewrite this expression in its elasticity form to yield:

$$
E V^{U}=z^{m}\left(p^{1}, Y\right) p^{1}\left(\frac{\Delta p}{p^{1}}\right)\left[1+\left(\frac{\epsilon_{p}+\epsilon_{Y} \xi}{2}\right)\left(\frac{\Delta p}{p^{1}}\right)\right],
$$

where $\epsilon_{p}$ and $\epsilon_{Y}$ are, respectively, the price and income elasticities of the Marshallian demand function, and $\xi$ is the expenditure share of the staple food, which is constant in this model. In our model, $\epsilon_{p}=1 / b=-1$. The Marshallian demand for all urban households under the new price is $Z^{m}\left(p^{1}, Y\right)=Q_{L}^{u *}, p^{1}=p_{L}^{r *}$, and $p^{0}=p_{S}^{r *}$. We can substitute these expressions into equation (13) and let $\psi=\left(\frac{1-\varepsilon / \gamma+2 \beta}{1-\varepsilon+2 \beta}\right)^{\beta}\left(\frac{\gamma}{\sigma}\right)^{\varepsilon}\left(\frac{2-\sigma_{L}(1-\varepsilon)}{1+\varepsilon / \gamma}\right)^{1-\varepsilon}$ to yield:

$$
E V^{U}=\frac{\bar{a}}{\sigma_{L}}(\Omega \psi-1)\left[1+\left(\frac{-1+\epsilon_{Y} \xi}{2}\right)(\Omega \psi-1)\right]
$$

as the measure of welfare change to an urban consumer in the large-farm equilibrium relative to the small-farm equilibrium.

Because rural households are both consumers and producers, their welfare change cannot be computed based on the standard EV. Instead, we derive the income transfer $\left(\Delta y^{R}\right)$ that would allow a rural household to achieve the maximized utility under the large-farm equilibrium, $u_{L}^{*}$, given the prices of consumed goods in the smallholder equilibrium.

$\Delta y^{R}$ is conceptually similar to $\mathrm{EV}$, but, unlike $\mathrm{EV}$, we need to fix the consumption of leisure at $l_{S}^{*}$ to keep the staple-food price, $p_{S}^{f *}$, and the shadow wage rate in the smallholder equilibrium 
unchanged, given the income transfer. If $u_{L}^{*}>u_{S}^{*}, \Delta y^{R}>0$, i.e., a positive income transfer is needed, and if $u_{L}^{*}<u_{S}^{*}, \Delta y^{R}<0$.

From FOCs (1) and (2), we know that the total expenditure on staple food and the nonfarm good equalize in equilibrium. Denote the new consumption levels of $x$ and $z$ required to achieve $u_{L}^{*}$ as $x_{S}^{\prime}$ and $z_{S}^{\prime}$ given prices in the smallholder equilibrium. These values are found by solving the following system of equations:

$$
\left\{\begin{array}{c}
\left(x_{S}^{\prime} z_{S}^{\prime} l_{S}^{*}\right)^{\frac{1}{3}}=u_{L}^{*}, \\
x_{S}^{\prime}=z_{S}^{\prime} p_{S}^{f *} .
\end{array}\right.
$$

The new level of staple food consumption is:

$$
z_{S}^{\prime}=\left(\frac{u_{L}^{*}}{l_{S}^{*} p_{S}^{f *}}\right)^{\frac{1}{2}} .
$$

It follows that the total income transfer required for all rural households, $\Delta Y^{R}=N \Delta y^{R}$, is: $\Delta Y^{R}=N\left[x_{S}^{\prime}+z_{S}^{\prime} p_{S}^{f *}-\left(x_{S}^{*}+z_{S}^{*} p_{S}^{f *}\right)\right]=2 N\left(z_{S}^{\prime}-z_{S}^{*}\right) p_{S}^{f *}$, where $x_{S}^{\prime}=z_{S}^{\prime} p_{S}^{f *}$ and $x_{S}^{*}=z_{S}^{*} p_{S}^{f *}$. Although $\Delta Y^{R}$ is cumbersome to express analytically, it can be easily computed numerically. Worth noticing, the number of rural households, $N$, is not in the final expression of $\Delta Y^{R}$.

Finally, we can compute the total welfare change in the economy by attaching equal weights to the welfare of urban and rural households and, thus, summing $E V^{U}$ and $\Delta Y^{R}$. In the following section, we quantify the welfare changes under reasonable values for the model parameters based on the empirical literature.

\subsection{Simulation Results}

We develop plausible ranges for $\sigma, \Omega$, and $\gamma$ values based on a survey of the empirical literature as summarized in Ma and Sexton (forthcoming) where 19 papers studying rice farming in developing countries in Asia and Africa are selected. The ranges of parameters are summarized in table 4.3. The mean output elasticities of labor and capital are 0.24 and 0.19 , respectively. 
Table 4.3 Simulation parameters

\begin{tabular}{cc}
\hline Parameter & Value \\
\hline$\sigma=\sigma_{S} / \sigma_{L}$ & $(0.4,0.6)$ \\
$\sigma_{L}$ & 0.4 \\
$\Omega$ & $(0.8,1)$ \\
$\gamma$ & $(2,5.7)$ \\
$\varepsilon$ & 0.19 \\
$\beta$ & 0.24 \\
$\epsilon_{Y}$ & 0.8 \\
$S_{0}$ & 0.2 \\
\hline
\end{tabular}

\section{Staple Food Production}

First, we compare total production and urban consumption of staple food under the two production modes. Because $\frac{\partial R_{Q}}{\partial \gamma}<0, \frac{\partial R_{Q}}{\partial \Omega}<0, \frac{\partial R_{Q}}{\partial \sigma}>0, \frac{\partial R_{Q} U}{\partial \gamma}<0, \frac{\partial R_{Q} U}{\partial \Omega}<0$, and $\frac{\partial R_{Q^{U}}}{\partial \sigma}>0$, we draw a hyperplane in a space with $\Omega, \sigma$, and $\gamma$ being the three dimensions. Any combination of $(\Omega, \sigma, \gamma)$ above the hyperplane result in $R_{Q}<1$ and $R_{Q^{U}}<1$, meaning that the corresponding quantity is higher under large-farm production.

As shown in the figure, only when $\Omega$ and $\gamma$ are sufficiently small and $\sigma$ sufficiently large, would $R_{Q}>1$ and $R_{Q^{U}}>1$. Given that the literature suggests that $\gamma$ is most likely to be larger than $2, R_{Q}$ is most likely to be smaller than 1 .

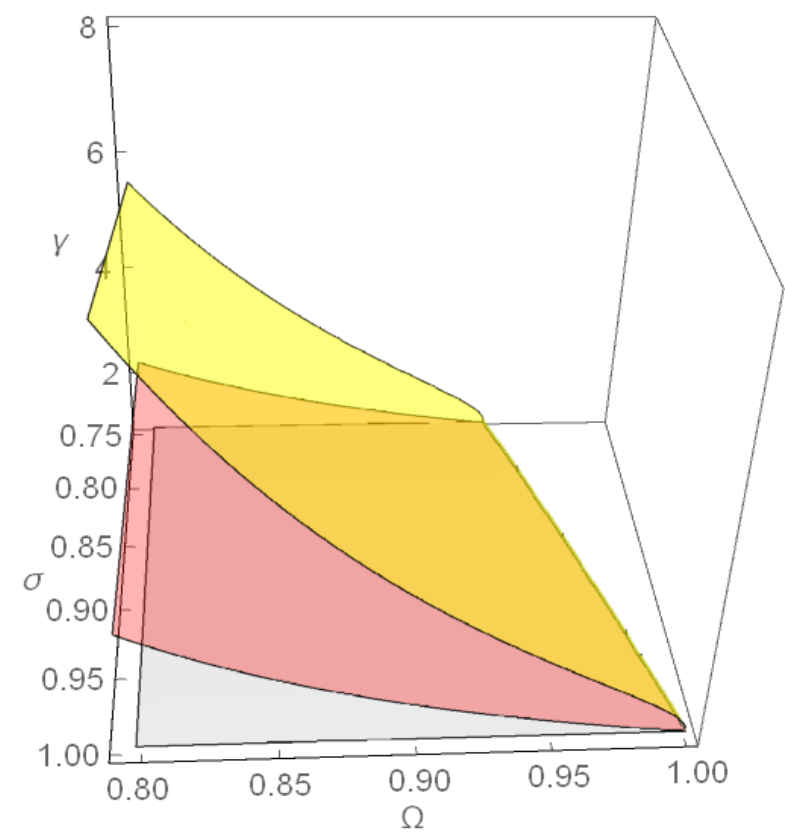

\section{Figure 4.1 Production and Urban Consumption of the Staple Food}

Notes: Authors' calculation. The yellow hyperplane represents $R_{Q}=1$, while the red hyperplane represents $R_{Q^{U}}=$ 1. The gray plane contains all points with $\gamma=1$. 


\section{Staple Food Price}

Comparing the rural and urban prices for staple food under two production modes, all combinations of $(\Omega, \sigma, \gamma)$ beneath the red hyperplane in figure 4.1 imply $R_{p^{f}}<1$, and all $(\Omega, \sigma, \gamma)$ beneath the yellow hyperplane in figure 4.2 imply $R_{p^{r}}<1$.

It turns out that the two ratios tend to have opposite relative magnitudes against 1 . Combinations of $(\Omega, \sigma, \gamma)$ below the red hyperplane and above the yellow hyperplane imply $R_{p^{f}}<1$ and $R_{p^{r}}>1$. Combinations of $(\Omega, \sigma, \gamma)$ above both hyperplanes imply $R_{p^{f}}>1$ and $R_{p^{r}}>1$, meaning that both rural and urban households pay low prices for staple food under large-farm production.

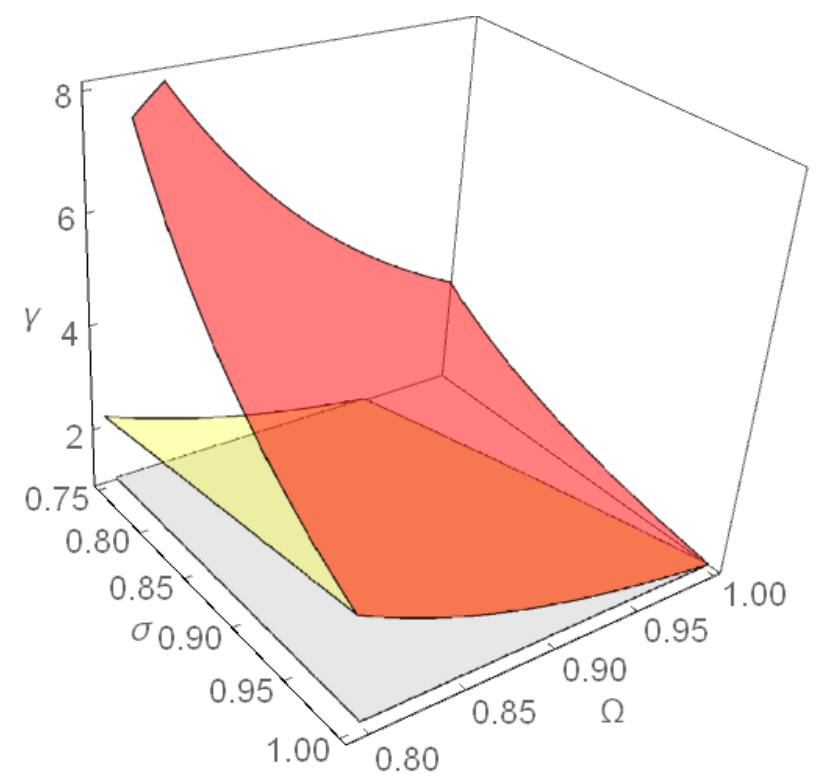

Figure 4.2 Rural and Urban Prices of the Staple Food

Notes: Authors' calculation. The red hyperplane represents $R_{p^{f}}=1$, while the yellow $R_{p^{r}}=1$. The gray plane contains all points with $\gamma=1$.

\section{Equivalent Variation of Urban Households}

Since we only observe the expenditure share under the initial price (i.e., under smallholder production), we can express $S^{1}$ using $S^{0}$. The expression of relative EV becomes

$$
\widetilde{E V}=S_{0}\left(\frac{1+\varepsilon}{1+\varepsilon / \gamma}\right)(\Omega \psi-1)\left[1+\left(-\frac{1}{2}+\frac{\epsilon_{Y}^{1}(1+\varepsilon) S^{0}}{2(1+\varepsilon / \gamma)}\right)(\Omega \psi-1)\right]
$$

Letting $\epsilon_{Y}^{1}=\epsilon_{Y}^{0}=0.8$ and $S^{0}=0.2$, the magnitude of $\widetilde{E V}$ is calculated given value ranges of $\Omega$ and $\sigma$ and a particular $\gamma$. Again, as the literature suggests, the shadow price of credits in imperfect credit markets is at least twice as large as the bank interest rate and can be as high as 
5.7 times as large (Sial \& Carter, 1996). We plot $\widetilde{E V}$ for $\gamma=2,3,4$, and 6 in figure 4.3. For easier interpretation, we measure $\widetilde{E V}$ in percentage form.

The lower the efficiency of credit markets for smallholders, the higher the relative EV for urban households tends to be if transforming to large-farm production. The relative EV also increases in the marketing margin of smallholders and the efficiency of hired labor on large farms. When $\gamma$ ranges from 3 to $6, \widetilde{E V}$ is likely to account for as much as $4-8 \%$ of the total expenditure of urban households.

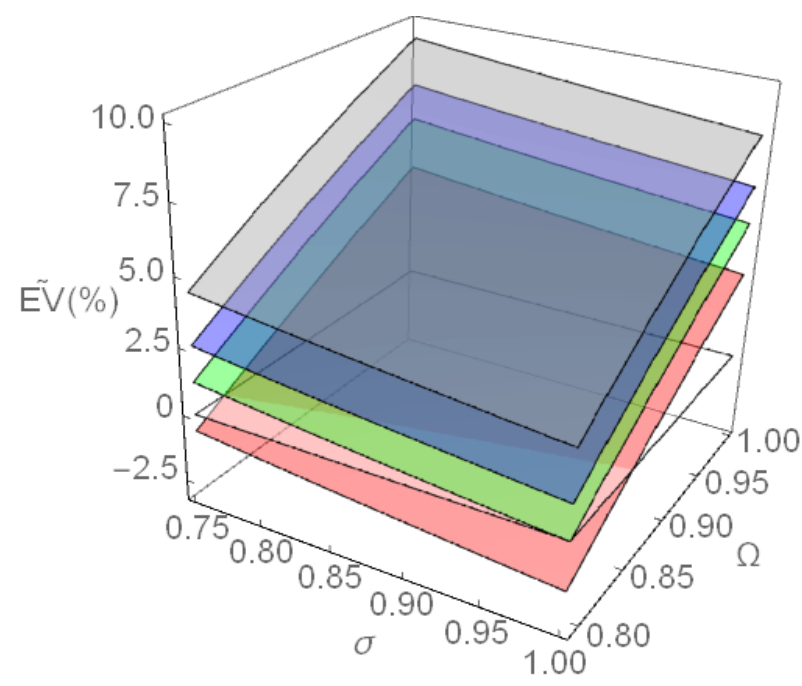

\section{Figure 4.3 Equivalent Variation for Urban Households}

Notes: Authors' calculation. The red hyperplane represents the value of relative EV for a particular $(\Omega, \sigma)$ and $\gamma=$ 2. Similarly, the green hyperplane represents the value of relative $\mathrm{EV}$ for a particular $(\Omega, \sigma)$ and $\gamma=3$, the blue hyperplane corresponds to $\gamma=4$, and the gray hyperplane corresponds to $\gamma=6$. The white hyperplane indicates $\widetilde{E V}=0$. Except for the red hyperplane, all hyperplanes are strictly above the white hyperplane.

\section{Social Welfare Changes}

There are two to consider social welfare change. First, we compare $R_{u}$ and $E V$. When $R_{u}<1$ and $E V>0$, we have a win-win scenario where both urban and rural households gain from the transformation of smallholder farms. If $R_{u}>1$ and $E V<0$, of course, we have a lose-lose scenario and so on. In figure 4.4, we draw a red hyperplane which represents $R_{u}=1$ and a yellow hyperplane which represents $E V=0$. Combinations of $(\Omega, \sigma, \gamma)$ below the red hyperplane and above the yellow hyperplane represents the win-win scenario. 


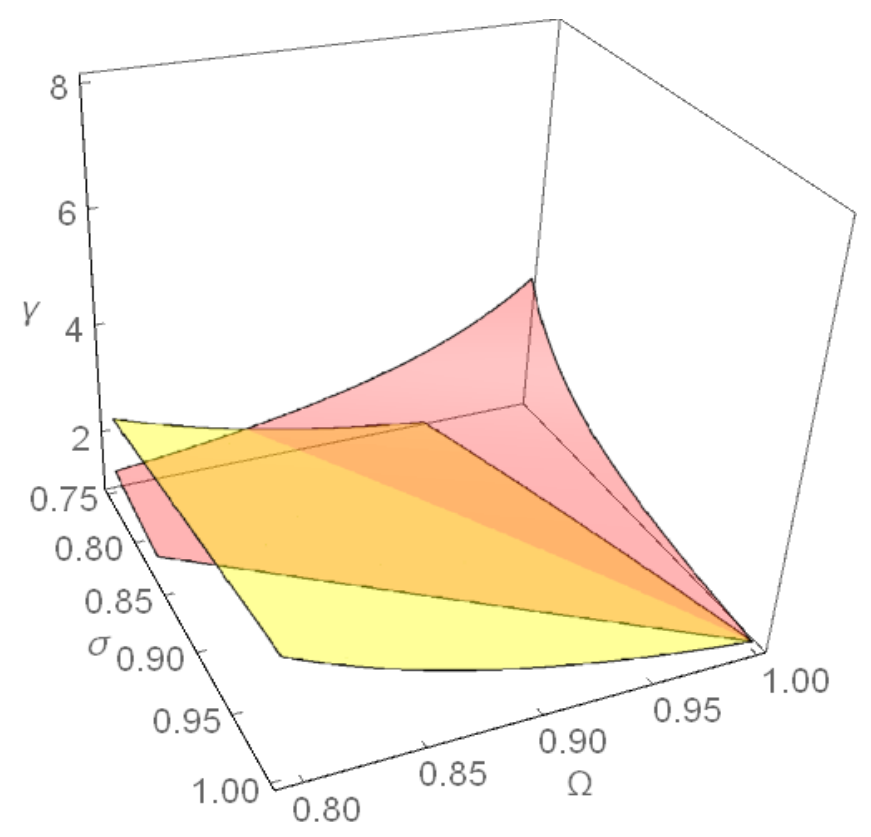

Figure 4.4 Welfare Changes of the Two Types of Households

Notes: Authors' calculation. The red hyperplane represents $R_{u}=1$, while the yellow hyperplane represents $E V=$ 0 . The gray plane contains all points with $\gamma=1$.

We can view this figure better by cutting the space along a particular value of $\sigma$. For example, if we cut through $\sigma=0.75$ and $\sigma=0.65$, we can separate scenarios into four areas in the figure below. In figure 4.5 (a), the green area on the right represents the win-win scenario. The light green area on the top represents a scenario where only urban households gain, while the light green area on the bottom represents a scenario where only rural households gain. The remaining white area refers to the lose-lose scenario which is much smaller relative to the sum of the other three scenarios.

Figure 4.5 (b) shows a similar pattern for a smaller $\sigma$. The area of the win-win scenario enlarges as $\sigma$, the marketing efficiency of smallholders decreases. In fact, when $\sigma=0.65$, there is no lose-lose scenario within ranges of our parameters. This means when the cost of marketing is relatively large for smallholders, the transformation of smallholder farming tends to benefit both rural and urban households. 


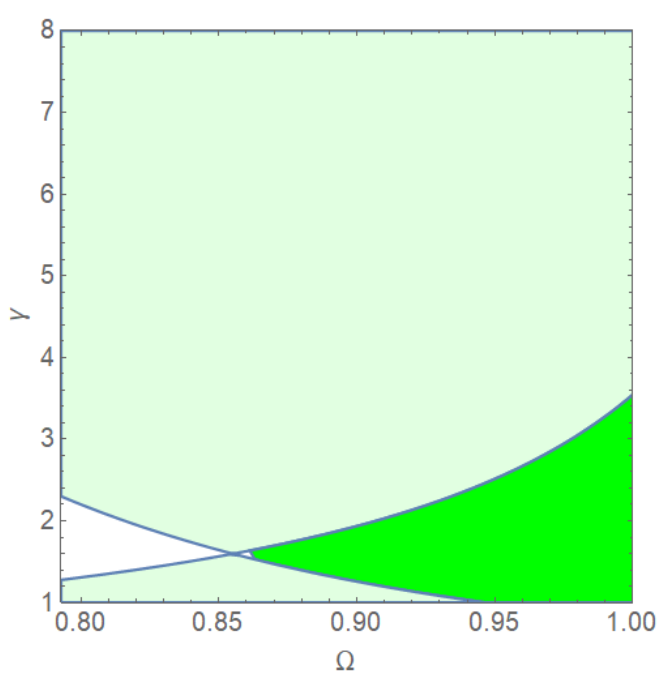

(a)

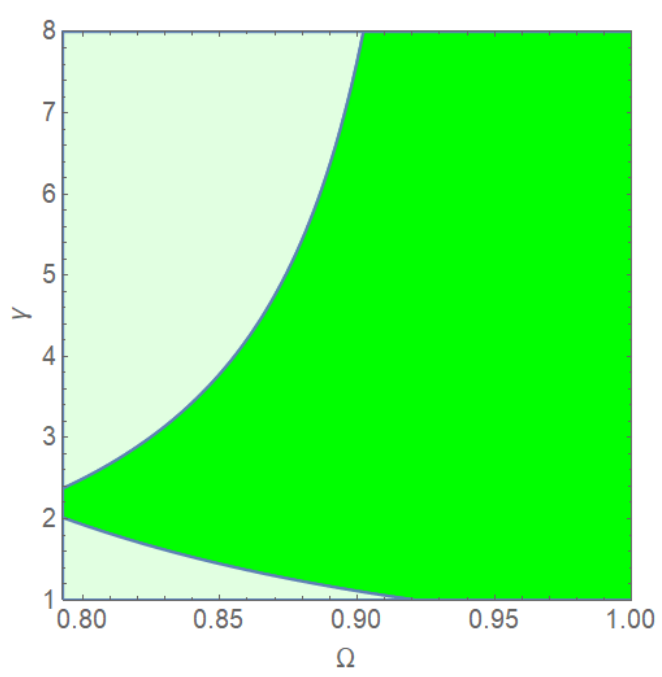

(b)

\section{Figure 4.5 Welfare Changes of the Two Types of Households}

Notes: Authors' calculation. Figure (a) is drawn given $\sigma=0.75$, and Figure (b) is drawn given $\sigma=0.65$. The green area on the right represents the win-win scenario (i.e., $R_{u}<1, E V>0$ ), while the light green area on the top represents a scenario where only urban households gain (i.e., $R_{u}>1, E V>0$ ). The light green area on the bottom represents a scenario where only rural households gain (i.e., $R_{u}<1, E V<0$ ), while the remaining white area refers to the lose-lose scenario (i.e., $R_{u}>1, E V<0$ ).

Alternatively, we compute the total welfare of all households in the economy following equation (5). Expressing $S^{1}$ by a function of the observed $S^{0}$, we rewrite $W^{\text {social }}$ as

$$
\begin{gathered}
2\left[\frac{(1-\varepsilon+2 \beta) \beta}{1-\varepsilon / \gamma+2 \beta}+(1-\varepsilon-\beta)-\sigma+\sigma \varepsilon / \gamma\right] \\
+(1-\varepsilon / \gamma)\left[2 \sigma-\frac{1}{\Omega \psi}-\left(\frac{1-\varepsilon+2 \beta}{1-\varepsilon / \gamma+2 \beta}\right)\right] \\
+\frac{(1+\varepsilon)}{\sigma_{L}}(\Omega \psi-1)\left[1+\left(-\frac{1}{2}+\frac{\epsilon_{Y}^{1}(1+\varepsilon) S^{0}}{2(1+\varepsilon / \gamma)}\right)(\Omega \psi-1)\right]
\end{gathered}
$$

The magnitude of $W^{\text {social }}$ is independent of the proportion of rural households (i.e., $\phi$ ) in the economy. If $W^{\text {social }}>0$. The economy as a whole gains from the transformation of smallholder farmers. Even if only rural or urban households gain under $W^{\text {social }}>0$, the government could make income transfers across households to make Pareto improvement for all.

Again, we compute $W^{\text {social }}$ by varying magnitudes of key parameters. Note $\sigma_{L}$ needs to be specified in this case. We set $\sigma_{L}=0.9$ in the baseline simulation. It turns out that $W^{\text {social }}$ is only marginally affected by the value $\sigma_{L}$. We plot $W^{\text {social }}$ for $\gamma=2,3,4$, and 6 in figure 4.6. The value of $W^{\text {social }}$ increases in $\gamma$. Importantly, $W^{\text {social }}$ is positive as long as $\gamma>3$. Thus, 
the transformation of smallholder farms is likely to bring Pareto improvement to the economy given general economic conditions in smallholder-based agricultural economies.

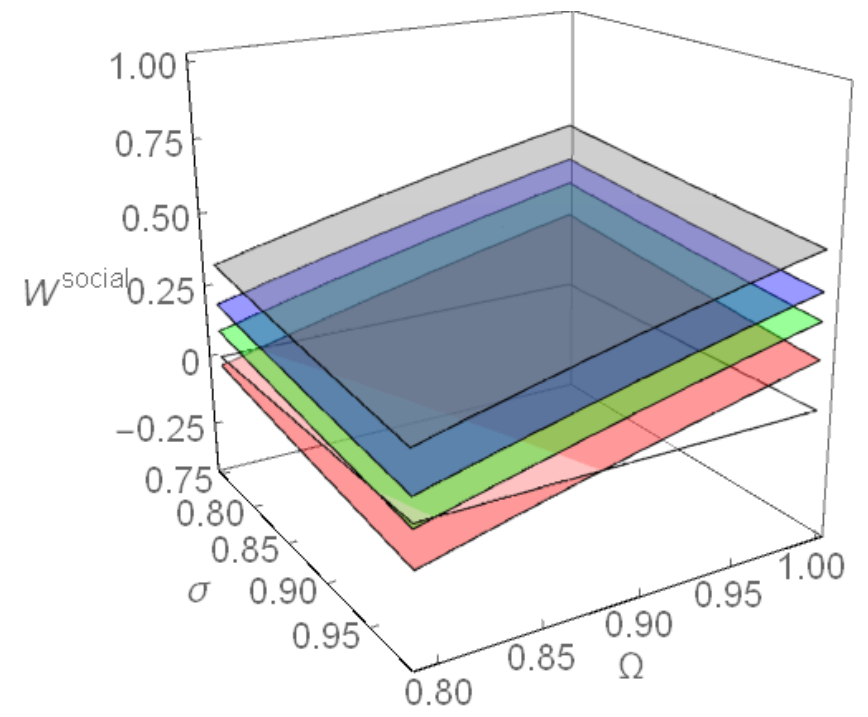

Figure 4.6 Total Welfare Change of the Two Types of Households

Notes: Authors' calculation. The red hyperplane represents the value of $W^{\text {social }}$ for a particular $(\Omega, \sigma)$ and $\gamma=2$. Similarly, the green hyperplane corresponds to $\gamma=3$, the blue hyperplane corresponds to $\gamma=4$, and the gray hyperplane corresponds to $\gamma=6$. The white hyperplane indicates $W^{\text {social }}=0$. 


\subsection{Discussion and Conclusion}

This study extends the Ma-Sexton model and assesses how the welfare of domestic consumers changes when rural smallholder farming transitions to selling or renting landholdings and supplying labor to larger commercial farms. We add to the literature by looking into the effects of when the increased output is directed towards staple commodities sold in the home country market. Through a range of plausible parameters, our simulation results suggest that urban consumers and rural households can benefit through this transformation, in particular lowincome households who tend to spend more income on staple food.

First, we show that the production and consumption of staple food by urban consumers is higher under large farm production. Second, both rural and urban households pay lower prices for staple food under the large farm scenario. The price decrease of staples enables an extra sum of expenditure that is used to purchase food from other food groups that have higher levels of income elasticity. In addition to the increased livelihood options for smallholders, poor urban consumers can intuitively, as a result, buy staple commodities at a lower price, improving their overall diet. Lastly, we show that as intermediary costs $(\sigma)$ decreases, which is often the case under commercial farm operations, the cost of marketing lowers. This leads to an increasing win-win situation for both rural and urban households.

Understanding the relationship between increased farm production due to land consolidation and the effect of urban household's food security has many relevant policy implications. With rapid population and income growth in developing countries, there are concerns as to how to meet the rising demand for food and the food security status of the poor. Though new market opportunities for the farming sectors are arising along with economic development, much of the urban food consumption demands in African countries are becoming dependent on imports (FAO, 2011), thus, increasing their vulnerability to world market shocks.

The transformation to commercial agriculture is possible if supportive institutions are in place, as shown by the rapid transformation that has taken place in high-value export sectors (Ma \& Sexton, forthcoming). Though much of domestic institutions and international donors' policies emphasize the important role of smallholder farming in economic development and poverty reduction, our findings shed light on the effects of the emergence of larger farms. Our results imply that if this transition is enabled, then both small farming households and urban consumers can gain from increased income due to higher levels of farm productivity. The findings of this paper provide the first step to encourage governments in developing countries to not only loosen restrictions on land consolidation but to also implement programs targeted at consolidating farmlands to increase output productivity and to reduce poverty and hunger in the long run. 


\section{Appendix}

\section{Observed Expenditure Share of the Staple Food}

Expenditure share under smallholder production and large-farm production can be expressed below, respectively.

$$
\begin{gathered}
S^{0}=\frac{\frac{(1+\varepsilon / \gamma) \bar{a}}{2}}{Y} \\
S^{1}=\frac{\frac{(1+\varepsilon) \bar{a}}{2}}{Y}
\end{gathered}
$$

Thus, we can express

$$
S^{1}=S_{0} \frac{1+\varepsilon}{1+\varepsilon / \gamma}
$$

The relative $\mathrm{EV}$ is rewritten as

$$
\widetilde{E V}=S_{0}\left(\frac{1+\varepsilon}{1+\varepsilon / \gamma}\right)(\Omega \psi-1)\left[1+\left(-\frac{1}{2}+\frac{\epsilon_{Y}^{1}(1+\varepsilon) S^{0}}{2(1+\varepsilon / \gamma)}\right)(\Omega \psi-1)\right]
$$

\section{Shadow Price of Leisure for Rural Households}

$$
\begin{gathered}
p_{S}^{f *} \frac{\partial f}{\partial t^{*}}=p_{S}^{f *} \beta(1-l)^{\beta-1} k^{\varepsilon} \\
=\frac{\bar{a} \sigma(1-\varepsilon / \gamma+2 \beta)}{2 N}
\end{gathered}
$$

Thus, the EV based on the Slutsky compensated demand is

$$
\begin{gathered}
E V^{S}=e\left(p^{0}, x^{0}\right)-e\left(p^{1}, x^{0}\right)=z_{S}^{*}\left(p_{S}^{f *}-p_{L}^{f *}\right)+l_{S}^{*}\left(w_{S}^{*}-w^{*}\right) \\
=\frac{\bar{a}(1-\varepsilon / \gamma)}{2 N}\left[2 \sigma-\frac{1}{\Omega \psi}-\left(\frac{1-\varepsilon+2 \beta}{1-\frac{\varepsilon}{\gamma}+2 \beta}\right)\right]
\end{gathered}
$$




\section{Conclusion}

In the past decades, there has been a rapid expansion of global value chains across the world. Several factors are driving this development, such as increasing income, urbanization, and improved infrastructure (Reardon et al., 2003). At the same time, food supply chains are upgrading to meet demands with mechanisms to document testing procedures to ensure food safety and improvements of processing facilities and storage systems (Maertens et al., 2012). This has created opportunities for the agrifood sector in developing countries to participate in modern value chains. Yet, in the course of this process, many smallholders who participate in these value chains still face challenges that prevent them from benefitting from these opportunities. Studies have shown that with the presence and support of institutions, there are benefits to countries as a whole and for smallholder households in terms of agricultural productivity (Fulginiti et al., 2004; M. Lio \& Liu, 2008) and participation in global value chains (Dollar et al., 2016). This dissertation addresses this phenomenon by assessing the role of institutions in the integration and development of modern agricultural value chains. Chapters 2 to 4 present the three papers that define the central focus of this dissertation.

Chapter 2 presents the first paper titled "The role of institutional quality on the performance in the export of coconut products" aimed to answer three research questions. First, we are interested in how the overall institutional environment in exporting countries affects the bilateral trade of coconut products. Second, we look into whether improvements in the exporters' individual indicator scores lead to an increase in trade with consideration to the exporters' and importers' overall institutional setting. Lastly, we investigate the effects of institutional similarities for coconut trade and its different compositions of value addition. To address these questions, we utilize structural gravity models to measure how institutional quality affects the export performance of the top 26 coconut producing countries to the top 15 importing economies over the years 1996-2016. Our results suggest that increased government effectiveness enhances trade of high-value products, hinting that further processing of coconut products is enabled by the provision of contract enforcement and complementary services. Conversely, better voice and accountability scores decrease the trade of coconut products in both categories of value addition, implying that more voice and rights to farmers and laborers could complicate the value-adding process and border trading of coconut products.

The third chapter investigates the challenges and opportunities of a small island nation's integration into the global value chain with an emphasis on the role of institutions titled "Fiji's participation in the global coconut value chain: Opportunities and constraints". This chapter 
first follows the previous paper and looks into the effect of institutional indicators on the performance in the export of coconut products from Fiji. The empirical results show that increased scores in the government effectiveness and voice and accountability indicators enhance coconut exports from Fiji, suggesting that institutional quality in the home country plays an important role. Second, I conducted semi-structured interviews with key stakeholders in the Fijian coconut sector. The interviews reveal that communications among each stakeholder group are fragmented. The main institutional actors and the producers have different perceptions of the industry's challenges, thus resulting in different ideas on how to address the issues. Interviews further confirm that the existing value chain is rudimentary and limited to low-value products such as copra and crude oil. The existing land tenure system creates further disincentives for smallholders to invest time and energy in managing coconut groves and replanting.

Chapter 4 of my dissertation takes a theoretical approach to look into modern agricultural systems by analyzing the demand side. It follows the overall storyline of this dissertation by emphasizing the importance of institutions and what could happen if institutions enabled smallholders to end farm operations to supply land and labor inputs to larger commercialized farms. The paper builds on previous research (Ma \& Sexton, forthcoming) that assess the future of smallholder farming systems in modern agricultural value chains. We address the unanswered questions as to how the productivity effect can affect the welfare of domestic consumers if the increased output is directed towards staple crops sold in the home country. Furthermore, we show how lower prices from increased production can improve the dietary diversity of urban consumers. Since poorer urban households are likely to have high budget shares yet low-income elasticities for staple crops, they benefit when the price of staples decreases as a result of commercialization. Consumption of other food groups expands, thus, enhancing dietary diversity and likely the nutritional health of the urban poor.

Some general conclusions and implications can be drawn from the results of these chapters. First, we confirm that institutions matter, but not merely as one entity. Different aspects of institutional quality affect integration differently. When assessing coconut producing countries collectively, the findings of our first paper in Chapter 2 suggest that government effectiveness matters the most when enhancing trade of coconut products of varying degrees of value edition, while the indicator, voice and accountability, had contrasting effects. However, findings from Chapter 3 demonstrates that for Fiji, a small island economy, both government effectiveness and voice and accountability increase Fiji's export of coconut products. This implies that the heterogeneities of each country play a role and must be taken into consideration for future 
research. Results from the third chapter bolster this argument. Each country has its specific institutional set-up and enabling environment, thus, the integration of each will differ albeit to a lesser or greater degree than another.

Results from chapter 4 show that through a range of plausible parameters, urban consumers benefit when the price of staples decreases as a result of farm commercialization. The price decrease of staples enables simplicity extra income for households to spend on foods that have higher levels of income elasticity, such as animal proteins. Our findings support the argument that though government policies and international donors' support for smallholder farms often stem from egalitarian reasons, there are benefits for both smallholders and urban poor consumers if land transfers are allowed from small to commercial farms. This is particularly the case when supplies home countries are becoming increasingly unable to meet rising quantity demands.

\subsection{Limitations and Reflections}

I dove into the dark when I picked coconut as the commodity to study to fit my GlobalFood subproject topic. The coconut sector is largely ignored in the literature and I became convinced that the boom in organic and other certified coconut products in the Western market would prove to be fruitful in research. The research on coconuts provides interesting insights as to how this very specific commodity plays a role in people's livelihoods. Furthermore, it sheds light on how the attitude towards this crop varies largely depending on the opportunity smallholders and processors have in the region. I hope my work will encourage future research work on the economics of the coconut sector. Writing the paper in Chapter 4 is equally ambitious as microeconomic theory and analysis were not my strong points. Yet, I felt like the topic is important and relevant. The learning curve is high and the thought of going into unknown territory sparked the motivation in me. These decisions proved to be worth the risk. Nonetheless, there are some limitations and important lessons learned throughout this process. In the following section, I discuss the lessons I have learned in the journey to writing the three chapters of my dissertation as well as some reflections and thoughts.

\section{Paper I}

One major limitation in the first paper of my dissertation was the unavailability of data. Though coconut products are sold widely in developed countries, trade data remains limited. This proved to be a bottleneck once the ball started rolling on this paper. 
One of the original ideas when I began this Ph.D., is to look at how agricultural policies can affect the integration of coconut markets. It's unfortunate that the database for Distortions to Agricultural Incentives is only compiled up to 2007. If data from later years were also, it would then be possible to assess how institutions and policy together can influence how much coconut (or other commodities) trade there is. The agrifood system has drastically altered in 13 years. Due to the attention and relevance of policy implications of research nowadays, it would be crucial to assess the role of specific policies on value chain integration.

The United Nations Trade Statistics Database (UN Comtrade) has one of the most comprehensive datasets in commodity trade. However, the data is limited to the six digits in the Harmonized System (HS) codes. As a result, products with higher levels of value addition are clustered into broad categories such as "fresh or dried, desiccated". Coconut items such as virgin coconut oil, coconut water, and coconut milk belong in the eight-digit codes. This first chapter tries to deal with this by assuming that the coconut producing countries in the study do not export items such as almond milk and hazelnut milk. We can only speculate if the results would be different had eight-digit codes data been available, perhaps the differences could be in the margins.

This paper is also limited by the inability to address the heterogeneities among and within coconut producing countries. I emphasize the role of transaction costs as channels that influence international exchange. We thus neglect that transaction costs vary not only with institutional quality but also with human capital per worker (Costinot, 2009). A handful of countries dominate coconut production. The nations range from large economies like Brazil to small ones such as Kiribati with smallholders who depend on the cultivation of coconuts for their livelihoods. Our version of the gravity model tries to address some heterogeneities by implementing importer fixed effects. However, issues such as within-country heterogeneities are not captured.

We attempt to measure how institutions affect products with different levels of value addition. However, institutional indicators do not allow for the assessment of product categories individually. We have in part addressed this by showing the trade effect for the entire agricultural sector. Nevertheless, in a macro-level study, we are unable to identify winners and losers individually with institutional indicators that assess the entire economy. Our study focuses exclusively on coconut exports, therefore, our findings should not be seen as transferrable to other crops and commodities. Further research is needed in other agricultural products with various levels of value addition to study the influence of institutions and governance on international market integration. 
Dealing with multilateral resistance in the study's version of the gravity model is a major challenge and a major roadblock in writing the second chapter. In an earlier version of the paper, we implemented importer-time-product fixed effects, exporter-product fixed effects, and time-product fixed effects with the intention of characteristics that are not observed over time per exporter, per importer, and per product in the basic model (Anderson \& Van Wincoop, 2003). Yet, as Fally (2015), points out, in the PPML model, the inclusion of exporter-year fixed effects synonymous with conditioning on the total value of exports in the given year. As a result, only the relative trade costs are identified (Yotov, 2012). Whether institutions increase the overall coconut exports evenly cannot be identified because the institutional variable only varies at the exporter-year level. In the end, the bonus-vetus method (Baier \& Bergstrand, 2009) is to be the best way to address multilateral resistance for the purpose of this paper.

Lastly, there is no question in the importance of studying institutions and the role it has on trade and integration. Nonetheless, it remains difficult to find a database that is able to fully undertake the notion of "institutions".

\section{Paper II}

The second paper of my dissertation stems from my desire to gain a deeper understanding of the challenges that face smallholders who engage in coconut production. The field research involves qualitative methods, which has shown to have several limitations for analysis from an economic standpoint. The aim is to understand their perceptions. However, the lack of quantitative data does pose restraints. First, it is challenging to avoid researcher bias when conducting interviews and data analysis. It is difficult to determine and assess the systematic reasoning for farmer's participation in copra making. All information was obtained according to word of mouth, therefore, it does imply problems regarding the internal validity of the study. However, because there are no clear definitions nor indicators as to what poses constraints to a specific commodity sector, the study had to rely on qualitative interviews with actors in the industry.

My ambition to conduct this qualitative research alone proved to be more difficult than I had anticipated. The decision to go to Fiji stemmed from a collaboration with CIRAD to produce a manual on risk assessment of coconut value chains in the Pacific Islands. Because of this cooperation, the time of travel had to be in sync with the staff member at CIRAD. Though I did receive generous support from the team at the Ministry of Agriculture, I underestimated the difficulty of conducting semi-interviews and discussions alone. Also, since the participants were mainly selected by ministry staff, it perhaps biased some perceptions over others. Local 
staff members in Fiji and the international organization I worked with possess good knowledge of navigating the islands and how to communicate with farmers. Through this, I learned that it is valuable to know the strengths of each organization in the field and utilize them for my purposes.

In this paper, I assume that smallholders can benefit from their participation in global value chains. We were unable to assess how much of an increase in income would be for coconut producers if they could participate in the global market. A future research question could be in what conditions do farmers benefit from integration into global value chains? The idea that farmers would benefit if they were able to produce higher-value products and integrate globally is ambiguous. Whereas Maertens and Swinnen (2009) show that incomes in Senegal increased with increasing production of high-value products for exports, Schipmann and Qaim's (2010) research on sweet peppers in Thailand shows no difference in income when smallholder sell to modern supply chains as opposed to traditional markets.

I encountered difficulties during the analysis and writing phase. I, of course, knew that people who specialize in qualitative research is limited in Goettingen. Thus, I had my struggles and battles that I hadn't foreseen. I finished the paper with a great and relevant story, but I nonetheless encountered difficulties to present it in a scientific manner.

\section{Paper III}

The study considers a partial equilibrium model with no product differentiation. We also assume the price to be exogenous. The limitations, thus, are the lack of consideration for product differentiation, exogenous variables such as climate variations, and assessment of the effect on other markets. As Carletto et al. (2015) point out if there is a household level influence of agriculture and nutrition or in the paper's purpose, food security, "they are most likely the result of one or a combination of these factors-higher agricultural income, market imperfections (resulting in greater consumption of own consumption) and gender-related factors" (p. 949).

There is a tradeoff when taking a partial equilibrium approach as opposed to using a general equilibrium model. We look into detail about the effect of the food sector. By doing this, we omit the possibilities of the substitution effect on non-agricultural items. For instance, in urban areas, there is a higher share of indirect consumption from cereal grains in processed forms (Valin et al., 2014). Furthermore, processed goods are likely to be more elastic to income than raw commodities (Valin et al., 2014).

Our model does not take intra-household heterogeneities into account. A unitary model could inaccurately represent households' decisions when treating households as a single decision unit 
maximizing a common utility function (Attanasio \& Lechene, 2014). Different consumption patterns and preferences over how extra income should be spent may lead to a difference in both income and price elasticities (De Vreyer et al., 2020).

The study relies on past papers to obtain figures for the price elasticity of demand for staple commodities in developing countries. The literature utilized in the paper nonetheless had their limitations that might lead to biases in the numbers. The countries of focus for these studies are also limited. Though our focus is in developing countries, the majority of the studies were in more or less the same countries. We added Brazil and South Africa to the study because the studies involved seemed reliable.

Lastly, the paper assumes that an increase in consumption of other food items leads to an increase in food security. This model ignores gender dynamics in households. Some evidence hints that depending on the household members that control the resources, the effects of changes in income will differ (Quisumbing, 2003). Food security itself is a difficult concept to define fully. This implicates the type of proxies that should be measured as food security-food, caloric, micronutrient, or dietary diversity indicators.

\subsection{Future Research Agenda}

A span of three years was a limited amount of time to achieve what one hopes out of a Ph.D. There were more ideas and that could not be realized due to time constraints. This sets up a good setting for some future research prospects. First, since the third paper is fresh in memory, I would like to extend the analysis of this paper with a general equilibrium framework and study the economy-wide impacts of conversion to modern agricultural markets and value where the demand functions are based on end consumption of household items (Valin et al., 2014). One cannot address the concept of food security without exploring the dietary and nutritional diversity of urban consumers. As mentioned already, the challenge is to find the correct proxy for the analysis. Additionally, I am interested in proposing an additional consideration of the current model that explicitly studies spatial effects and urban consumer's distance to the market.

Secondly, subject to data availability, there is much left to explore in smallholders in the global coconut sector and how it relates to the smallholders who are involved. Though the craze has lessened, there persists a market for high-value coconut items. For instance, it would be interesting to compare the market of virgin coconut oil versus coconut oil. Various brands of both items can be found on the market, but, very little data exist in how much of each is being traded globally. Furthermore, though much of high-value coconut products found in Western 
supermarkets have one or more standard or certifications, there is limited data that exist on coconut certification and standards. If data were available, then it would be worthwhile to look at how dynamics between institutions and certifications obtained by smallholder farmers.

Another idea that I would like to work on in the future is the concept of food waste in lowincome countries. With urbanization and rising incomes can also result in an increase in inequality. How does change the perceptions of people's attitudes towards food waste? Additionally, if according to the findings of Chapter 4, the urban poor consumes more staple food and diversify their diets into other food groups, does this also increase the amount of food wasted? The findings of such a study would have high policy implications.

Finally, these last three years of Ph.D. life have taught me a lot about the world of conducting research and publishing these works. Beyond research and empirical skills and training, I learned the importance of communications across cultures and the importance of patience and composure. I entered with higher levels of idealism and I will leave with those same ideals combined with some realism. Nonetheless, I have my idealistic yearnings for my career vision in the next several years. I wish to utilize my policy background and sociological thinking and combine them with my economic training and skills to develop innovative empirical studies and direct research projects that focus on the welfare impacts of policies and programs on smallholder farmers and rural households. Specifically, I wish to address the mechanisms in which smallholders can benefit from deeper integration into global value chains and how the rest of society could gain from potential spill-over effects. I want to reach further than being a research scientist. I aim to be part of a force that aims to implement on the ground projects that value local and indigenous knowledge. Ultimately, I wish to work with people in the field who have visions of their own and to provide outputs that entail policy recommendations. 


\section{References}

Abe, K. \& Wilson, J.S. (2008). Governance, corruption, and trade in the Asia-Pacific region. World Bank Policy Research Working Paper No. 4731. Washington, DC: The World Bank Group.

Abdulai, A., \& Aubert, D. (2004). A cross-section analysis of household demand for food and nutrients in Tanzania. Agricultural Economics, 31, 67-79.

Abdulai, A., Jain, D. K., \& Sharma, A. K. (2008). Household Food Demand Analysis in India. Journal of Agricultural Economics, 50(2), 316-327.

Abdulsamad, A. (2016). Connecting to the world market through regional value chains: Partnership Opportunities in Coconut Value Chain for the Small Caribbean Economies. The Duke University Global Value Chains Center.

Acemoglu, D., Johnson, S., \& Robinson, J. A. (2005). Institutions as a Fundamental Cause of Long-Run Growth. In Handbook of Economic Growth, 1, 385-472.

Adam, C., \& Cobham, D. (2007). Modeling multilateral trade resistance in a gravity model with exchange rate. Centre for Dynamic Macroeconomic Analysis Conference Papers, $44,1-49$.

Adamopoulos, T., \& Restuccia, D. (2014). The size distribution of farms and international productivity differences. American Economic Review, 104(6), 1667-1697.

ADB. 2013. Re-invigorating private sector investment: A private sector assessment for Fiji Asian Development Bank.

Álvarez, I. C., Barbero, J., Rodríguez-Pose, A., \& Zofío, J. L. (2018). Does Institutional Quality Matter for Trade? Institutional Conditions in a Sectoral Trade Framework. World Development, 103, 72-87.

Amare, M., Mariara, J., Oostendorp, R., \& Pradhan, M. (2019). The impact of smallholder farmers' participation in avocado export markets on the labor market, farm yields, sales prices, and incomes in Kenya. Land Use Policy, 88.

Amiri, H., Samadian, F., Yahoo, M., \& Jamali, S. J. (2019). Natural resource abundance, institutional quality and manufacturing development: Evidence from resource-rich countries. Resources Policy, 62, 550-560.

Anderson, J. E., \& Marcouiller, D. (1999). Trade, insecurity, and home bias: an empirical investigation. NBER Working Paper 7000. Cambridge, MA: National Bureau of Economic Research.

Anderson, J. E., \& Marcouiller, D. (2002). Insecurity and the Pattern of Trade: An Empirical Investigation. Review of Economics and Statistics, 84(2), 342-352.

Angelucci, F., \& Conforti, P. (2010). Risk management and finance along value chains of Small Island Developing States. Evidence from the Caribbean and the Pacific. Food Policy, 35(6), 565-575.

Arias, P., Hallam, D., Krivonos, E., \& Morrison, J. (2013). Smallholder Integration in 
changing Food Markets. In Food and Agriculture Organization of the United Nations (FAO). www.fao.org/

Arvis, J. F., Shepherd, B., Duval, Y., \& Utoktham, C. (2013). Trade Costs and Development: A New Data Set. Economic Premise, No. 104. Washington, DC. The World Bank Group.

Baier, S. L., \& Bergstrand, J. H. (2009). Bonus vetus OLS: A simple method for approximating international trade-cost effects using the gravity equation. Journal of International Economics, 77(1), 77-85.

Bawalan, D. (2010). Feasibility study on the wholenut coconut multipurpose processing enter concept in Fiji. FAO Report: Suva, Fiji.

Barrett, C. B., Bellemare, M. F., \& Hou, J. Y. (2010). Reconsidering Conventional Explanations of the Inverse Productivity-Size Relationship. World Development, 38(1), 88-97.

Barrientos, S., \& Asenso-Okyere, K. (2009). Cocoa value chain: challenges faacing Ghana in a changing global confectionary market. Journal Fur Entwicklungspolitik, 25(2), 88107.

Batugal, P., Rao, V. R., \& Oliver, J. (2005). Coconut Genetic Resources. Coconut Genetic Resources. International Plant Genetic Resources Institute - Regional Office for Asia.

Bawalan, D. (2010). Feasibility study on the wholenut coconut multipurpose processing center concept in Fiji, FAO Report: Suva, Fiji.

Bellemare, M. F., \& Novak, L. (2017). Contract farming and food security. American Journal of Agricultural Economics, 99(2), 357-378.

Belloc, M. (2006). Institutions and international trade: A reconsideration of comparative advantage. Journal of Economic Surveys, 20(1), 3-26.

Ben Ali, M. S., \& Mdhillat, M. (2015). Does corruption impede international trade? New evidence from the EU and the MENA countries. Journal of Economic Cooperation and Development, 36(4), 107-120.

Berden, K., Bergstrand, J. H., \& van Etten, E. (2014). Governance and globalisation. World Economy, 37(3), 353-386.

Berger, D., Easterly, W., Nunn, N., Satyanath, S., Amegashie, A., Baier, S., Bonfatti, R., Chisik, R., Dragusanu, R., Essaji, A., Feenstra, R., Head, K., Helpman, E., Katz, L., Mckeown, T., Maurer, N., Meissner, C., Miguel, E., Mitchener, K., Reiter, D. (2013). Commercial Imperialism? Political Influence and Trade During the Cold War. American Economic Review, 103(2), 863-896.

Berkowitz, D., Moenius, J., \& Pistor, K. (2006). Trade, Law, and Product Complexity. Review of Economics and Statistics, 88(2), 363-373. https://doi.org/10.1162/rest.88.2.363

Bijman, J., Muradian, R., Cechin, A., \& Cechin, A. (2012). Agricultural Cooperatives and Value Chain Coordination. In Value Chains Social Inclusion and Economic Development: Contrasting Theories and Realities (pp. 82-101).

Birner, R., \& Resnick, D. (2010). The Political Economy of Policies for Smallholder 
Agriculture. World Development, 38(10), 1442-1452.

Bitzer, V., Van Wijk, J., Helmsing, A. H. J. B., \& Van Der Linden, V. (2012). Partnering to Facilitate Smallholder Inclusion in Value Chains. Value Chains Social Inclusion and Economic Development: Contrasting Theories and Realities, 221-246.

Bojnec, S., \& Ferto, I. (2015). Institutional determinants of agro-food trade. Transformations in Business and Economics, 14(2) 35-52.

Borgatti, L. (2008). Pacific Islands' bilateral trade: The role of remoteness and of transport costs. Journal of International Development, 20, 486-501.

Boydell, S. (2010). South Pacific Land: An alternative perspective on tenure traditions, business, and conflict. Georgetown Journal of International Affairs, 11(1), 17-26.

Breisinger, C., Raouf, M., Thurlow, J., \& Wiebelt, M. (2019). Beyond the business case for agricultural value chain development An economywide approach applied to Egypt. 18. Washinton, DC.

Breisinger, C., \& Diao, X. (2008). Economic transformation in theory and practice: What are the messages for Africa? International Food Policy Research Institute Vol. 797: Washington, DC.

Bula, S. (n.d.). Integrated approach in the processing of coconut products/ by-products and market prospects in Fiji. Retrieved March 13, 2019, from https://library.apccsec.org/paneladmin/doc/20180409072101Sekope Bula.56.pdf

Butkiewicz, J. L., \& Yanikkaya, H. (2006). Institutional quality and economic growth: Maintenance of the rule of law or democratic institutions, or both? Economic Modelling, 23(4), 648-661.

Carletto, G., Ruel, M., Winters, P., \& Zezza, A. (2015). Farm-level pathways to improved nutritional status: Introduction to the special issue. Journal of Development Studies, 51(8), 945-957.

Carter, M. R., \& Zimmerman, F. J. (2000). The dynamic cost and persistence of asset inequality in an agrarian economy. Journal of Development Economics, 63(2), 265-302.

Christopher, M., \& Peck, H. (2004). Building the Resilient Supply Chain. The International Journal of Logistics Management, 15(2), 1-14. https://doi.org/10.1108/09574090410700275

CIA. 2019. Fiji. The World Factbook 2019. Washington, DC.

Colen, L., Melo, P. C., Abdul-Salam, Y., Roberts, D., Mary, S., \& Gomez Y Paloma, S. (2018). Income elasticities for food, calories and nutrients across Africa: A metaanalysis. Food Policy, 77, 116-132

Connell, J. (2006). "The taste of paradise": Selling Fiji and FIJI Water. Asia Pacific Viewpoint, 47(3), 342-350.

Cornelsen, L., Green, R., Turner, R., Dangour, A. D., Shankar, B., Mazzocchi, M., \& Smith, R. D. (2015). What happens to patterns of food consumption when food prices change? Evidence from a systematic review and meta-analysis of food price elasticities globally. 
Health Economics, 24, 1548-1559.

Costinot, A. (2009). On the origins of comparative advantage. Journal of International Economics, 77(2), 255-264.

Courtois, P., \& Subervie, J. (2015). Farmer bargaining power and market information services. American Journal of Agricultural Economics, 97(3), 953-977.

Daude, C., \& Stein, E. (2007). The quality of institutions and foreign direct investment. Economics and Politics, 19(3), 317-344.

de Groot, H., Linders, G. J., \& Rietveld, P. (2005). Institutions, governance and international trade. IATSS Research, 29(2), 22-29.

de Groot, H. L. F., Linders, G. J., Rietveld, P., \& Subramanian, U. (2004). The institutional determinants of bilateral trade patterns. Kyklos, 57, 103-124.

Deans, H., Ros-Tonen, M. A. F., \& Derkyi, M. (2018). Advanced value chain collaboration in ghana's cocoa sector: An entry point for integrated landscape approaches? Environmental Management, 62(1), 143-156.

Degain, C., \& Maurer, A. (2015). Implications of global value chains for statistics and trade policy. In Xing, Y. (Ed.), Uncovering value-added in trade (pp 9-45). Tokyo: World Scientific.

Demont, M., \& Ndour, M. (2015). Upgrading rice value chains: Experimental evidence from 11 African markets. Global Food Security, 5, 70-76.

Den Butter, F. a. G., \& Mosch, R. H. J. (2003). Trade, trust and transaction costs. SSRN Electronic Journal.

Diao, X., Cossar, F., Houssou, N., and Kolavalli, S. (2014). Mechanization in Ghana: Emerging demand, and the search for alternative supply models. Food Policy, 48, 168181.

Diao, X., Thurlow, J., Benin, S., \& Fan, S. (Eds.). (2012). Strategies and priorities for African agriculture: economywide perspectives from country studies. Washington, DC: IFPRI.

Diao, X., Hazell, P., Resnick, D., \& Thurlow, J. (2007). The role of agriculture in development: Implications for Sub-Saharan Africa. Research report no. 153. Washington, DC: IFPRI.

Dijk, M. P. Van, \& Trienekens, J. (2012). Global Value Chains Linking Local Producers. Amsterdam University Press: Amsterdam.

Dillon, A., Mcgee, K., \& Oseni, G. (2015). Agricultural Production, Dietary Diversity and Climate Variability. The Journal of Development Studies, 51(8), 976-995.

Djankov, S., Freund, C., \& Pham, C. S. (2010). Trading on Time. Review of Economics and Statistics, 92(1), 166-173.

Dollar, D., Ge, Y., \& Yu, X. (2016). Institutions and Participation in Global Value Chains. Global Value Chain Development Report Background Paper. Washington, DC: The World Bank Group. 
Dollar, D., \& Kidder, M. (2017). Institutional quality and participation in global value chains. International Bank for Reconstruction and Development: Measuring and Analyzing the Impact of GVs on Economic Development, 161-173.

Dorward, A. (2012). The short- and medium- term impacts of rises in staple food prices. Food Security, 4(4), 633-645.

Dreher, A., \& Gassebner, M. (2013). Greasing the wheels? The impact of regulations and corruption on firm entry. Public Choice, 155, 413-432.

Duc, C., Lavallée, E., \& Siroën, J. M. (2008). The gravity of institutions. Economie Internationale, 113(1), 95-113.

Duncan, R., \& Sing, Y. W. (2009). The Failure of Agricultural Policymaking in Fiji The Failure of Agricultural Policymaking in Fiji. Pacific Economic Bulletin, 24(2), 2-26.

Ecker, O., \& Qaim, M. (2011). Analyzing Nutritional Impacts of Policies: An Empirical Study for Malawi. World Development, 39(3), 412-428.

Eicher, T. S., \& Leukert, A. (2009). Institutions and economic performance: Endogeneity and parameter heterogeneity. Journal of Money, Credit and Banking, 41(1), 197-219.

Fally, T. (2015). Structural gravity and fixed effects. Journal of International Economics, 97(1), 76-85.

FAO. 2013. Report of the FAO high-level expert consultation on coconut sector development. Bangkok, Thailand.

FAO. (2008). Country report on the state of plant genetic resources for food and agriculture. Suva, The Republic of Fiji.

Feder, G. (1985). The relation between farm size and farm productivity. The role of family labor, supervision and credit constraints. Journal of Development Economics, 18(2-3), 297-313.

Feder, G., Just, R. E., \& Zilberman, D. (1985). Adoption of agricultural innovations in developing countries: a survey. Economic Development \& Cultural Change, 33(2), 255298.

Feenstra, R. \& Taylor, A. (2004) International trade. New York: Worth Publishers.

Foale, M. (2003). The coconut odyssey: the bounteous possibilities of the tree of life. ACIAR Monograph No. 101, 132.

Francois, J., \& Manchin, M. (2013). Institutions, Infrastructure, and Trade. World Development, 46, 165-175.

Gaskell, J. C. (2015). The Role of Markets, Technology, and Policy in Generating Palm-Oil Demand in Indonesia. Bulletin of Indonesian Economic Studies, 51(1), 29-45.

Gereffi, G. (1994). The Organization of Buyer-Driven Global Commodity Chains: How US Retailers Shape Overseas Production Networks. In M. Gereffi, Gary; Korzeniewicz (Ed.), Commodity chains and global capitalism (Issue January). Praeger Publishers. 
Gereffi, G., Humphrey, J., \& Sturgeon, T. (2005). The governance of global value chains. Review of International Political Economy, 12(1), 78-104.

Green, A. H. (1991). Coconut production: present status and priorities for research. World Bank Technical Paper136. Washington, DC. The World Bank Group.

Guirkinger, C., \& Boucher, S. R. (2008). Credit constraints and productivity in Peruvian agriculture. Agricultural Economics, 39(3), 295-308.

Haggblade, S., Me-Nsope, N. M., \& Staatz, J. M. (2017). Food security implications of staple food substitution in Sahelian West Africa. Food Policy, 71, 27-38.

Hazell, P., Poulton, C., Wiggins, S., \& Dorward, A. (2010). The Future of Small Farms: Trajectories and Policy Priorities. World Development, 38(10), 1349-1361.

Heltberg, R. (1998). Rural market imperfections and the farm size-productivity relationship: evidence from Pakistan. World Development, 26(10), 1807-1826.

Henderson, H., \& Isaac, A. G. (2017). Modern value chains and the organization of agrarian production. American Journal of Agricultural Economics, 99(2), 379-400.

Horsewood, N., \& Voicu, A. M. (2012). Does corruption hinder trade for the new EU members? Economics, 6, 0-29.

Indexbox (2017). World coconut (copra) oil market report: Analysis and forecast to 2025. Walnut, United States.

Irvine, I. J., \& Sims, W. A. (1998). Measuring Consumer Surplus with Unknown Hicksian Demands. American Economic Review, 88(1), 314-322.

Ivanic, M., \& Martin, W. (2008). Implications of higher global food prices for poverty in lowincome countries. Agricultural Economics, 39(SUPPL. 1), 405-416.

Iwanow, T., \& Kirkpatrick, C. (2009). Trade Facilitation and Manufactured Exports: Is Africa Different? World Development, 37(6), 1039-1050.

Jensen, R. T., \& Miller, N. H. (2008). Giffen behavior and subsistence consumption. American Economic Review, 98(4), 1553-1577.

Johnson, V., \& Bourdeix, R. (2014). Global strategy for the conservation and use of coconut genetic resources, 2013-2013. Unpublished manuscript.

Juswanto, W., \& Ali, Z. (2014). Economic Growth and Sustainable Development in the Pacific Island Countries. Asian Development Bank Institute.

Kabir M., Salim, R., Al-Mawali, N. (2017). The gravity model and trade flows: Recent developments in econometric modeling and empirical evidence. Economic Analysis and Policy, 56, 60-71.

Kaplinsky, R., \& Morris, M. (2001). A Handbook for Value Chain Research. IDRC, 113.

Kaufmann, D., Kraay, A., \& Mastruzzi, M. (2009). Governance Matters VIII Aggregate and Individual Governance Indicators. Policy Research Working Paper No. 4978.

Washington, DC: The World Bank Group. 
Kaufmann, D., Kraay, A., \& Zoido-Lobaton, P. (1999). Aggregating governance indicators. Policy Research Working Paper No. 2195. Washington, DC: The World Bank Group.

Kazutomo, A., \& Wilson, J. S. (2008). Governance, corruption, and trade in the Asia Pacific region. Policy Research Working Paper No. 4731. Washingon, DC: The World Bank Group.

Kowalski, P., Lopez Gonzalez, J., Ugarte, R., \& Cristian, A. (2015). Participation of Developing Countries in Global Value Chains. OECD Trade Policy Papers 179.

Kumar, P., Kumar, A., Parappurathu, S., \& Raju, S. S. (2011). Estimation of Demand Elasticity for Food Commodities in India. Agricultural Economics Research Review, 24, $1-14$.

Kurtz, M. J., \& Schrank, A. (2007). Growth and governance: Models, measures, and mechanisms. Journal of Politics, 69(2), 538-554.

Langbein, L., \& Knack, S. (2010). The worldwide governance indicators: Six, one, or none? Journal of Development Studies, 46(2), 350-370.

Levchenko, A. A. (2013). International Trade and Institutional Change. Journal of Law, Economics, and Organization, 29(5), 1145-1181.

Li, Q., \& Resnick, A. (2003). Reversal of Fortunes: Democratic Institutions and Foreign Direct Investment Inflows to Developing Countries. International Organization, 57(01).

Lin, J., Flachsbarth, I., \& von Cramon-Taubadel, S. (2020). The role of institutional quality on the performance in the export of coconut products. Agricultural Economics, 51(2), 237258.

Linders, G., Slangen, A., de Groot, H., \& Beugelsdijk, S. (2005). Cultural and institutional determinants of bilateral trade flows. Tinbergen Institute Discussion Paper, TI 2005-07, $1-31$.

Lio, M. C., \& Hu, J. L. (2009). Governance and agricultural production efficiency: A crosscountry aggregate frontier analysis. Journal of Agricultural Economics, 60(1), 40-61.

Lio, M., \& Liu, M. C. (2008). Governance and Agricultural Productivity: A Cross-National Analysis. Food Policy, 33(6), 504-512.

Lowder, S. K., Skoet, J., \& Raney, T. (2016). The Number, Size, and Distribution of Farms, Smallholder Farms, and Family Farms Worldwide. World Development, 87, 16-29.

Ma, M., \& Sexton, R. (2020). Modern agricultural value chains and the future of smallholder farming systems. Agricultural Economics, forthcoming.

Maertens, M., \& Vande Velde, K. (2017). Contract-farming in Staple Food Chains: The Case of Rice in Benin. World Development, 95, 73-87.

Maertens, M., \& Swinnen, J. (2015). Agricultural trade and development: A value chain perspective. WTO Staff Working Paper, 39.

Maertens, M., Minten, B., \& Swinnen, J. (2012). Modern Food Supply Chains and Development: Evidence from Horticulture Export Sectors in Sub-Saharan Africa. 
Development Policy Review, 30(4), 473-497.

Maertens, M., Minten, B., \& Swinnen, J. (2009). Growth in high-value export markets in SubSaharan Africa and its development implications. LICOS Discussion Paper No. 24509. KU Leuven: Centre for Institutions and Economic Performance.

Magerman, G., De Bruyne, K., \& Van Hove, J. (2013). Revealed Multilateral Trade Resistance in Gravity Models-A Network Approach. The World Economy, 1-33.

Martin, W., \& Pham, C. S. (2015). Estimating the gravity model when zero trade flows are frequent. Policy Research Working Paper 7308. Washington, DC: The World Bank Group.

Martincus, C. V., \& Gallo, A. (2009). Institutions and export specialization: Just direct effects? Kyklos, 62(1), 129-149.

Martínez-Zarzoso, I., \& Márquez-Ramos, L. (2018). Exports and governance: Is the Middle East and North Africa region different? The World Economy, 42(1), 143-174.

Mason, N., \& Jayne, T. S. (2009). Staple Food Consumption Patterns in Urban Zambia: Results from the 2007/2008 urban consumption survey (Issue 42).

Mason, N. M., Jayne, T. S., Chapoto, A., \& Donovan, C. (2011). Putting the 2007/2008 global food crisis in longer-term perspective: Trends in staple food affordability in urban Zambia and Kenya. Food Policy, 36(3), 350-367.

Mauro, P. (1995). Corruption and Growth. The Quarterly Journal of Economics, 110(3), 681-

McGregor, A. M. (2007). The export of horticultural and high-value agricultural products from the Pacific islands. Pacific Economic Bulletin, 22(3).

Mendonça, T. G. de, Lirio, V. S., Braga, M. J., \& Silva, O. M. da. (2014). Institutions and Bilateral Agricultural Trade. Procedia Economics and Finance, 14, 164-172.

Méon, P. G., \& Sekkat, K. (2008). Institutional quality and trade: Which institutions? Which trade? Economic Inquiry, 46(2), 227-240.

Méon, P. G., \& Weill, L. (2005). Does better governance foster efficiency? An aggregate frontier analysis. Economics of Governance, 6, 75-90.

Minten, B., Reardon, T., \& Chen, K. Z. (2017). Agricultural value chains: How cities reshape food systems. In Global Food Policy Report.

Mitra, S., Mookherjee, D., Torero, M., \& Visaria, S. (2018). Asymmetric information and middleman margins: An experiment with Indian potato farmers. In Review of Economics and Statistics, 11(1), 1-13.

Mohan, S. (2016). Institutional Change in Value Chains: Evidence from Tea in Nepal. World Development, 78, 52-65.

Montalbano, P., Pietrelli, R., \& Salvatici, L. (2018). Participation in the market chain and food security: The case of the Ugandan maize farmers. Food Policy, 76(July 2017), 8198.

Mottaleb, K. A., Rahut, D. B., Kruseman, G., \& Erenstein, O. (2018). Changing Food 
Consumption of Households in Developing Countries: A Bangladesh Case. Journal of International Food and Agribusiness Marketing, 30(2), 156-174.

Muhammad, A., Seale J. L., J., Meade, B., \& Regmi, A. (2011). International evidence on food consumption patterns: An update using 2005 international comparison program data. Washington, DC: USDA-ERA.

Naresh Kumar, S., \& Aggarwal, P. K. (2013). Climate change and coconut plantations in India: Impacts and potential adaptation gains. Agricultural Systems, 117, 45-54.

Neilson, J., \& Shonk, F. (2014). Chained to Development? Livelihoods and global value chains in the coffee-producing Toraja region of Indonesia. Australian Geographer, 45(3), 269-288.

Nordas, H. K., \& Piermartini, R. (2004). Infrastructure and Trade. Staff Working Paper ERSD 2004-04. Lausanne: World Trade Organization.

North, D. C. (1991). Institutions. Journal of Economic Perspectives, 5(1), 97-112.

Oancea, A., Florez Petour, T., \& Atkinson, J. (2017). Qualitative network analysis tools for the configurative articulation of cultural value and impact from research. Research Evaluation, 26(4), 302-315.

O'Connell, S., Golub, S. S., Du, W. (2008). Export competitiveness and development in LDCs: Policies, issues and priorities for least developed countries for action during and beyond UNCTAD XII. Geneva: UNCTD.

OECD. (2020). Global value chains in agriculture and food: A synthesis of OECD analysis. Paris.

Ogutu, S. O., Gödecke, T., \& Qaim, M. (2019). Agricultural Commercialisation and Nutrition in Smallholder Farm Households. Journal of Agricultural Economics.

Pabuayon, I., Cabahug, R., Castillo, S.V., \& Mendoza, M. (2009). Key actors, prices and value shares in the Philippine coconut market chains: Implications for poverty reduction. J.ISSASS 15: 52-62.

Ponte, S., \& Gibbon, P. (2005). Quality standards, conventions and the governance of global value chains. Economy and Society, 34(1), 1-31.

Porter, M. (1985). The competitive advantage of nations. New York: Freedom Press, MacMillan.

Poulton, C., Dorward, A., \& Kydd, J. (2010). The Future of Small Farms: New Directions for Services, Institutions, and Intermediation. World Development, 38(10), 1413-1428.

Prades, A., Salum, U. N., \& Pioch, D. (2016). New era for the coconut sector. What prospects for research? OCL, 23(6), D607.

Prasad, B. C., \& Tisdell, C. (1996). Institutional Constraints to Economic Development: The Case of Native Land Rights in Fiji. Asia-Pacific Development Journal, 3(2), 49-71.

Prell, C., Hubacek, K., \& Reed, M. (2009). Stakeholder Analysis and Social Network Analysis in Natural Resource Management. Society \& Natural Resources: An 
International Journal, 22(6), 501-518.

Quisumbing, A. R. (2003). Household Decisions, Gender, and Development: A Synthesis of Recent Research. In Culture \& Agriculture, 29 (1). IFPRI.

Reardon, T., Timmer, C. P., Barrett, C. B., \& Berdegué, J. (2003). The rise of supermarkets in Africa, Asia, and Latin America. American Journal of Agricultural Economics, 85(5), 1140-1146.

Rigg, J., Salamanca, A., \& Thompson, E. C. (2016). The puzzle of East and Southeast Asia's persistent smallholder. Journal of Rural Studies, 43, 118-133.

Rodrik, D. (2000). How Far Will International Economic Integration Go? Journal of Economic Perspectives, 14(1), 177-186.

Ruel, M. T., Garrett, J. L., Hawkes, C., \& Cohen, M. J. (2010). The Food, Fuel, and Financial Crises Affect the Urban and Rural Poor Disproportionately: A Review of the Evidence. The Journal of Nutrition, 140(1), 170S-176S.

Sanchez, F. M. A., Restuccia, D., \& Rud, J. P. (2019). Are small farms really more productive than large farms? NBER Working Paper 26331. Cambridge, MA: National Bureau of Economic Research.

Santos Silva, J. M., \& Tenreyro, S. (2006). The log of gravity. The Review of Economics and Statistics, 88(4), 641-658.

Schipmann, C., \& Qaim, M. (2010). Spillovers from modern supply chains to traditional markets: Product innovation and adoption by smallholders. Agricultural Economics, 41(3-4), 361-371.

Selwyn, B. (2008). Institutions, Upgrading and Development: Evidence from North East Brazilian Export Horticulture. Competition \& Change, 12(4), 377-396.

Shepherd, B. (2013). The Gravity Model of International Trade: A User Guide. ARTNeT Books and Research Reports.

Sial, M. H., \& Carter, M. R. (1996). Financial market efficiency in an agrarian economy: Microeconometric analysis of the Pakistani Punjab. Journal of Development Studies, 32(5), 771-798.

Silsoe, A. (1963), Report on the Fiji coconut industry survey. Crown Agents, London.

Singh, I., Squire, L., \& Strauss, J. (1986). Agricultural household models: Extensions, applications, and policy. Johns Hopkins University Press, Baltimore, MD.

Skoufias, E., Di Maro, V., González-Cossío, T., \& Ramirez, S. R. (2011). Food quality, calories and household income. Applied Economics, 43(28), 4331-4342.

Srikala, P. V. (2020). Doubling Farmers' Income by 2022. International Journal of Management, 11(1), 9-14.

Streeten, P. (1993). The special problems of small countries. World Development, 21(2), 197202. 
Tefft, J., Jonasova, M., Adjao, R., \& Morgan, A. (2017). Food Systems for an Urbanizing World. Washington, DC: The World Bank Group.

Thomas, M. A. (2010). What do the worldwide governance indicators measure? European Journal of Development Research, 22(1), 31-54.

Tinbergen, J. (1962). Shaping the world economy. New York: Twentieth Century Fund.

Trienekens, J., \& Willems, S. (2007). Innovation and governance in international food supply chains the cases of Ghanaian pineapples and South African grapes. International Food and Agribusiness Management Review, 10(4), 42-63.

USDA (2018). Production volume of coconut oil worldwide from 2012/13 to 2017/18. In Statista - the Statistics Portal.

Valin, H., Sands, R. D., van der Mensbrugghe, D., Nelson, G. C., Ahammad, H., Blanc, E., Bodirsky, B., Fujimori, S., Hasegawa, T., Havlik, P., Heyhoe, E., Kyle, P., MasonD’Croz, D., Paltsev, S., Rolinski, S., Tabeau, A., van Meijl, H., von Lampe, M., \& Willenbockel, D. (2014). The future of food demand: Understanding differences in global economic models. Agricultural Economics, 45(1), 51-67.

Wall, G. (2016). Fiji: Tropical cyclone Winston. FAO Situation Report: Apia, Samoa,

Warner, B., Quirke, D., \& Longmore, C. (2007). A review of the future prospects for the world coconut industry and past research in coconut production and product. ACIAR: Canberra, Australia.

Yang, D., Sheng, S., Wu, S., \& Zhou, K.Z. (2018) Suppressing partner opportunism in emerging markets: Contextualizing institutional forces in supply chain management. Journal of Business Research, 90, 1-13.

Yotov, Y. V, Larch, M., Monteiro, J.-A., \& Piermartini, R. (2016). An Advanced Guide to Trade Policy Analysis: The Structural Gravity Model. January 2014, 1-144.

Young, D., \& Pelomo, M. (2014). Solomon Islands coconut value chain analysis. World Bank Group: Washington, DC.

$\mathrm{Yu}$, M. (2010). Trade, democracy, and the gravity equation. Journal of Development Economics, 91(2), 289-300.

Zhou, Y., \& Staatz, J. (2016). Projected demand and supply for various foods in West Africa: Implications for investments and food policy. Food Policy, 61, 198-212.

Zimmerman, F. J., \& Carter, M. R. (2003). Asset smoothing, consumption smoothing and the reproduction of inequality under risk and subsistence constraints. Journal of Development Economics, 71(2), 233-260.

Zylberberg, E. (2013). Bloom or bust? A global value chain approach to smallholder flower production in Kenya. Journal of Agribusiness in Developing and Emerging Economies, $3(1), 4-26$. 


\section{DECLARATIONS}

I. I hereby declare that this Ph.D. dissertation has not been presented to any other examining body in its present or a similar format.

I also affirm that I have not applied for a $\mathrm{Ph} . \mathrm{D}$. at any other higher educational institution.

Goettingen, 26.03.2020

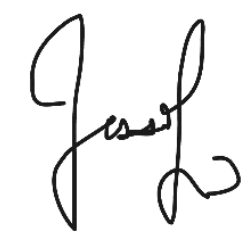

(Signature)

Jessie Lin

(Name in block capitals)

II. I hereby declare that this dissertation was undertaken independently and without unauthorized assistance.

Goettingen, 26.03.2020

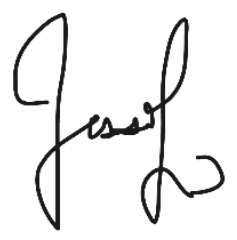

(Signature)

Jessie Lin

(Name in block capitals) 